\title{
Tuning DNA Supramolecular Polymers by the Addition of Small, Functionalized Nucleobase Mimics
}

Christophe Lachance-Brais ${ }^{1}$, Christopher D. Hennecker ${ }^{1}$, Asem Alenaizan ${ }^{2}$, Xin Luo ${ }^{1}$, Violeta Toader ${ }^{1}$, Monica Taing ${ }^{1}$, C. David Sherrill ${ }^{2}$, Anthony K. Mittermaier ${ }^{1}$, Hanadi F. Sleiman ${ }^{1 *}$

${ }^{1}$ Department of Chemistry, McGill University, 801 Sherbrooke St. W., Montreal, QC, H3A0B8, Canada

${ }^{2}$ School of Chemistry and Biochemistry, Georgia Institute of Technology, 901 Atlantic Drive, Atlanta, GA, 30332-0400, USA

\section{Supplementary Information}

\section{Table of Contents}

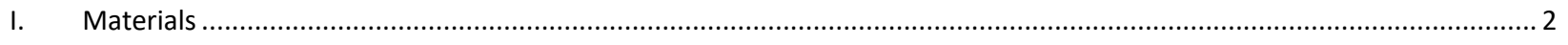

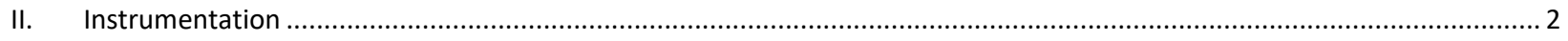

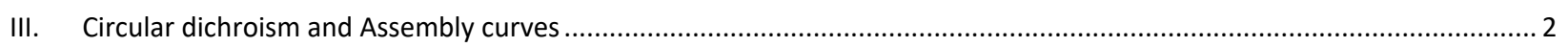

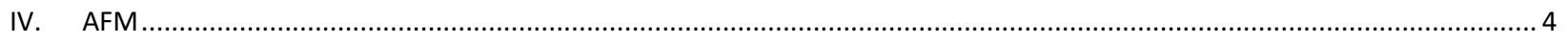

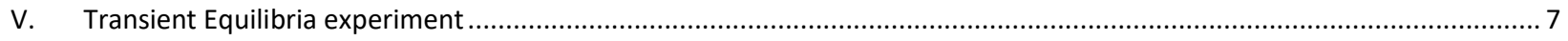

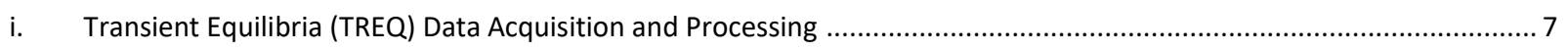

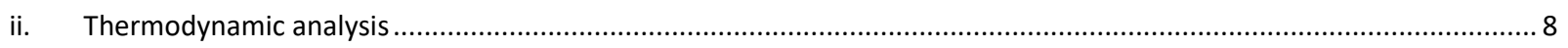

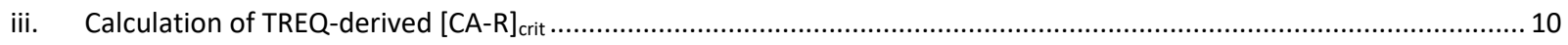

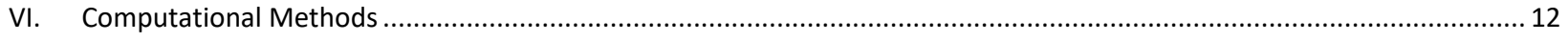

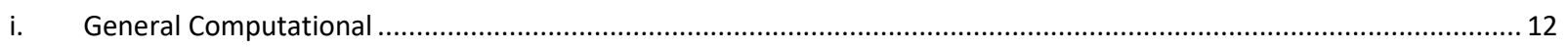

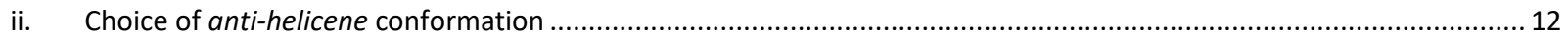

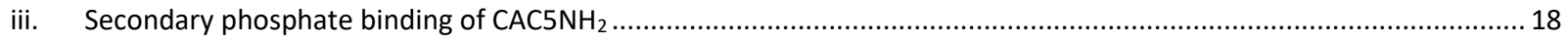

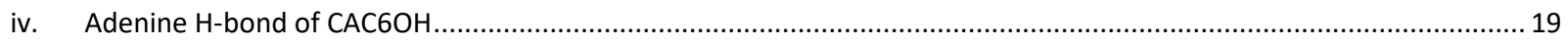

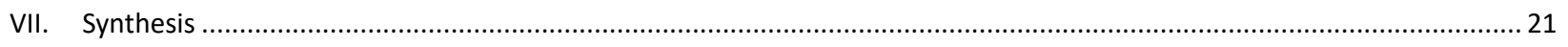

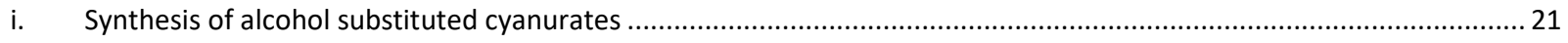

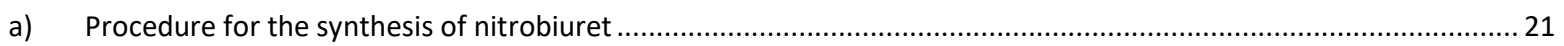

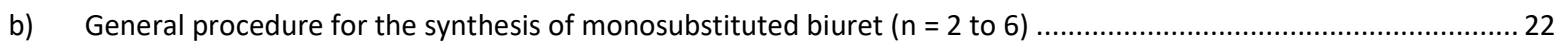

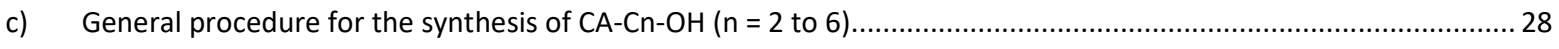

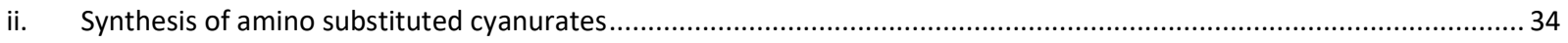

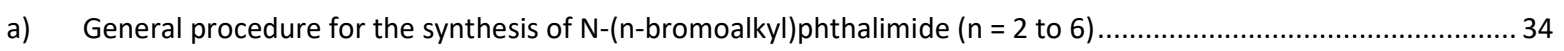

b) General procedure for the synthesis of 1 -( $n$-phthalimidoalkyl)-2,4,6-trioxo-1,3,5-triazine $(n=2$ to 6$) \ldots \ldots \ldots \ldots \ldots \ldots . . . . . . . .35$

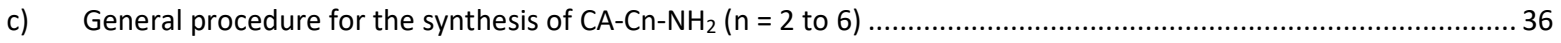




\section{Materials}

The polyadenine strands $\mathrm{dA}_{15}, \mathrm{dA}_{30}$ and $\mathrm{rA}_{15}$ were purchased desalted from Integrated DNA Technologies (IDT) a Cyanuric acid (CA) 98\%, diethylcarbonate 99\%, 21\% NaOEt in EtOH, potassium phthalimide 98\%, 1,n-dibromoalkane, n-hydroxy-1aminoalkane and 4-morpholineethanesulfonic acid hydrate (MES) were obtained from Sigma-Aldrich. Biuret 97\% was purchased from Fisher Scientific. 1xMESMg buffer is composed of $7.6 \mathrm{mM} \mathrm{MgCl}_{2}, \mathrm{MES} 50 \mathrm{mM}$ and adjusted with $\mathrm{NaOH}$.

\section{Instrumentation}

Circular Dichroism (CD) were performed on JASCO J-810 spectropolarimeter equipped with a Pelletier temperature controller, a xenon lamp and a water recirculator with a $0.1 \mathrm{~mm}$ path length quartz cuvette. UV-vis measurments were performed on a Cary 300 Series UV-Vis Spectrophotometer from Agilent connected to a water recirculator with a $1 \mathrm{~mm}$ quartz cuvette. Quantification of DNA and RNA were performed with a Nanodrop Lite spectrophotometer from Thermo Scientific. $\mathrm{pH}$ was measured using with a Mettler Toledo InLab Ultra-Micro $\mathrm{pH}$ electrode on a Thermo Scientific Orion 3-Star Plus pH meter. Thermal annealing of the samples was done on a Eppendorf Mastercycler Pro 96 well thermocycler. AFM images were collected on a Multimode 8 Scanning Probe Microscope from Bruker with a Nanoscope V controller equipped with a ScanAsyst-Air silicon tip on nitride lever (tip radius $=2 \mathrm{~nm}, \mathrm{k}=0.4 \mathrm{~N} / \mathrm{m}, \mathrm{f}_{\mathrm{o}}=70 \mathrm{kHz}$; Bruker).

\section{Circular dichroism and Assembly curves}

Stock solutions of CA-R in 1xMESMg buffer adjusted to $\mathrm{pH} 5.7$ were heated to $65^{\circ} \mathrm{C}$, sonicated then cooled down before use to prevent precipitate formation to vary concentration. Triplicate samples of the according concentration of CA-R and $25 \mu \mathrm{M}$ of $\mathrm{dA}_{30}$ or $\mathrm{rA}_{15}$ were prepared from the aforementioned stock solutions, 1xMESMg buffer. The samples were prepared in triplicates for each concentration point, with a control without CA-R and a blank of 1xMESMg buffer. Samples were annealed $\left(95.0^{\circ} \mathrm{C}\right.$ to $10.0{ }^{\circ} \mathrm{C}$ at $0.2{ }^{\circ} \mathrm{C} / \mathrm{min}$ ) prior to measurments. The cuvette was ice-cooled to transport samples to the $\mathrm{CD}$ instrument. $\mathrm{CD}$ curves were obtained in the wavelength range of $230-300 \mathrm{~nm}$ with $1 \mathrm{~nm}$ bandwidth, 4 s D.I.T. at $10.0^{\circ} \mathrm{C}$. The curves were smoothed using Savitzky-Golay filter.

Assembly curves were obtained by following. The Assembly curves were calculated using equation S1:

$$
F_{\text {assembled }}=\frac{I-I_{\min }}{I_{\max }-I_{\min }}
$$

Where $\mathrm{F}_{\text {assembled }}$ is the fraction assembled of the $\mathrm{dA}_{30}$ in the fibers, I is the intensity of the dip in the $245-255 \mathrm{~nm}$ region, $\mathrm{I}_{\max }$ and $I_{\min }$ are the maximum and minimum intensity of the aforementioned peak for a given CA-R. The [CA-R $]_{\text {crit }}$ is taken to reside within the interval between a concentration with no assembled fibers and the first point where fraction assembled is above 0 . 

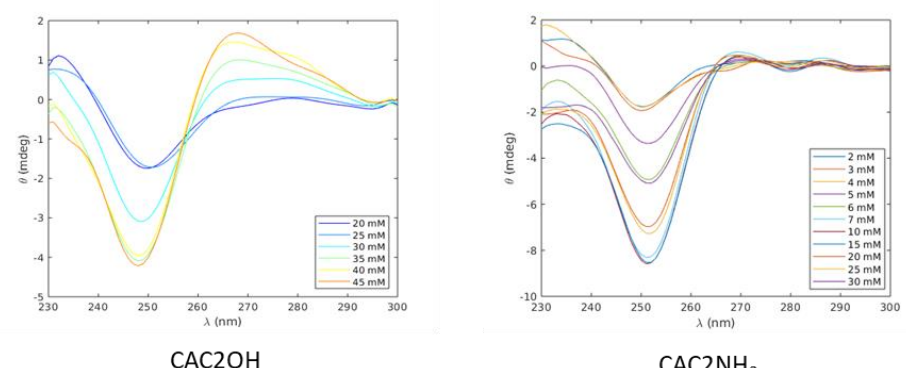

CAC2 $\mathrm{NH}_{2}$
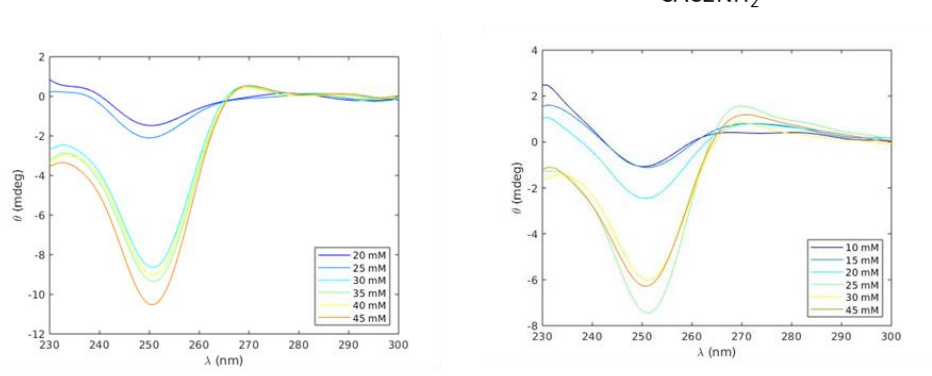

САСЗОН

$\mathrm{CAC} \mathrm{NH}_{2}$

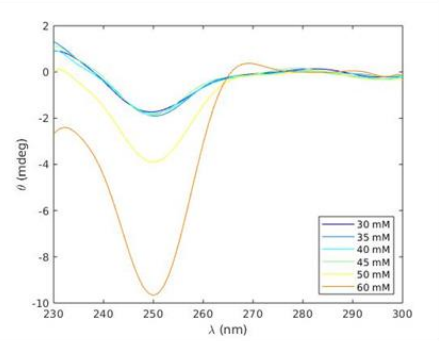

$\mathrm{CAC} 4 \mathrm{OH}$
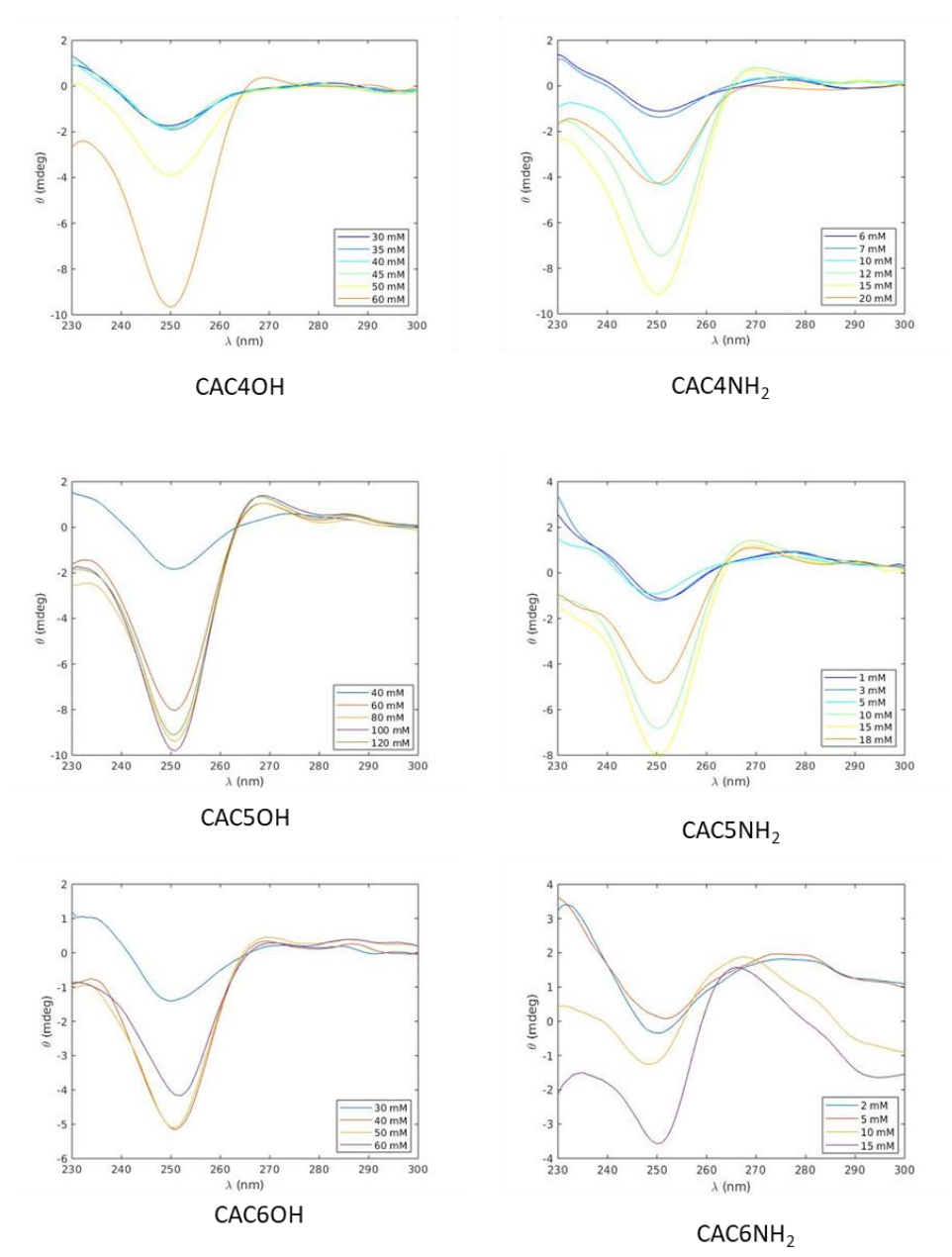

Figure S1 : Set of CD spectra of $\mathrm{d}_{30}$ with all the CA-R in the library at different concentrations. Only one of the three replicates is shown for each concentration. 


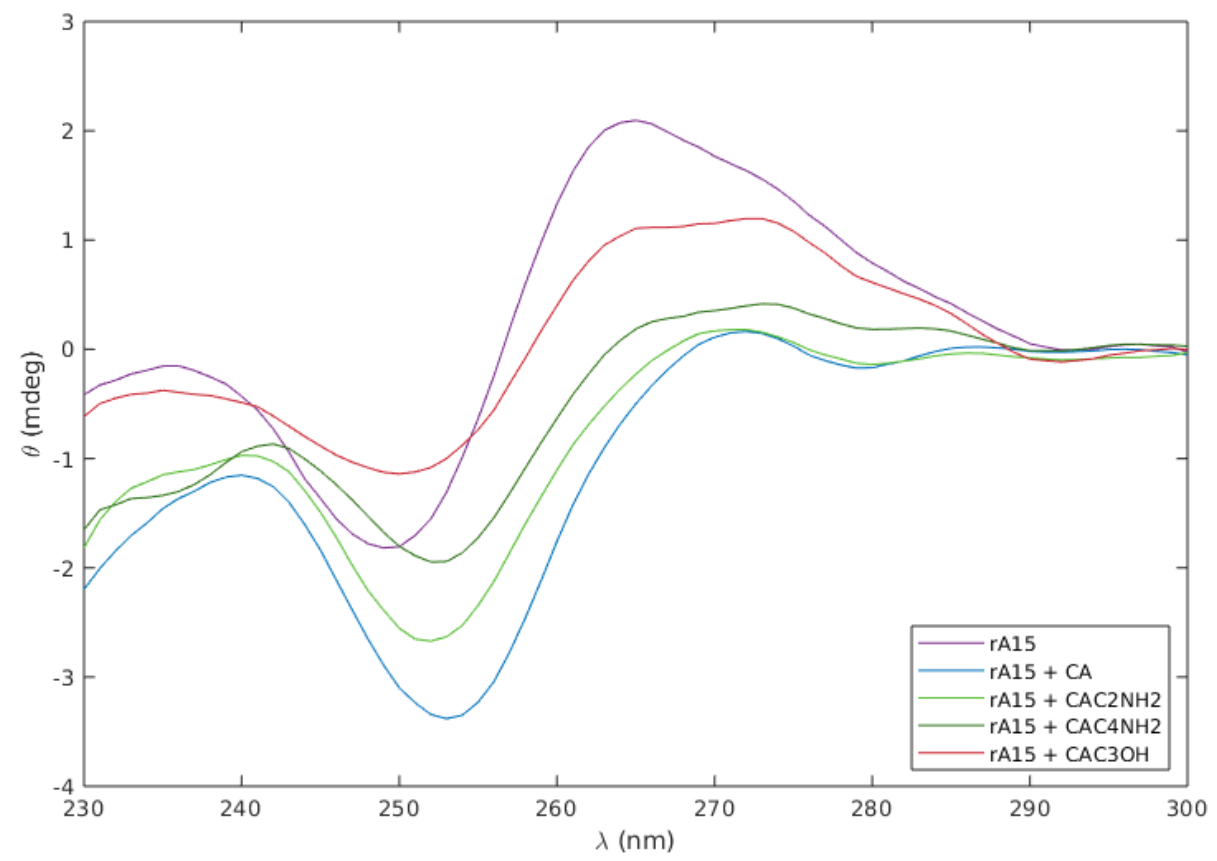

Figure S2 : Co-assembly of some CA-R with the RNA strand $\mathrm{rA}_{15}$. CD spectra of the mixture of $\mathrm{rA}_{15}$ with $\mathrm{CA}-\mathrm{C} 2-\mathrm{NH}_{2}(48 \mathrm{mM})$ and CA-C4-NH $\mathrm{NH}_{2}(22 \mathrm{mM})$ show similar signal as the assembly with CA $(19 \mathrm{mM})$. CA-C3-OH $(58 \mathrm{mM})$ has a different signal than both.

\section{AFM}

Samples for AFM imaging were prepared by depositing $5 \mu \mathrm{L}$ of the sample (containing 15 or $7.5 \mu \mathrm{M}$ DNA) onto a freshly cleaved mica surface for 30 seconds, followed by wicking off most of the liquid from the mica surface using a filter paper. The mica surface was then further dried under a stream of compressed air for 30 seconds before it was put under vacuum for at least 2 hrs prior to imaging. AFM images were acquired in ScanAsyst mode under air conditions.
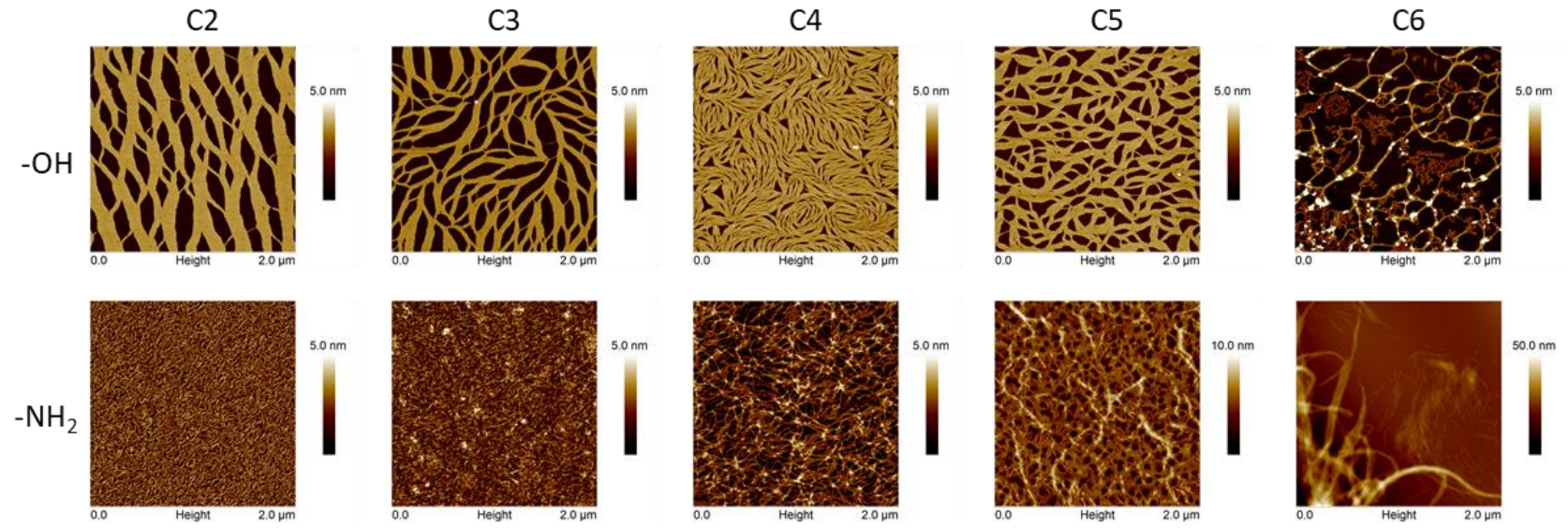

Figure S3 : Air AFM images of the various CA-R assembled with $\mathrm{dA}_{30}$. Fibrous structure is apparent for all CA-R, indicating that $\mathrm{CA}-\mathrm{R}$ interact with polyadenine in a similar way than the parent $\mathrm{CA}$ compound. Concentrations from left to right. $-\mathrm{OH}$ : 45mM; 50mM; 60mM; 80mM; 60mM-NH $: 25 \mathrm{mM} ; 35 \mathrm{mM} ; 25 \mathrm{mM} ; 25 \mathrm{mM} ; 25 \mathrm{mM}$. 

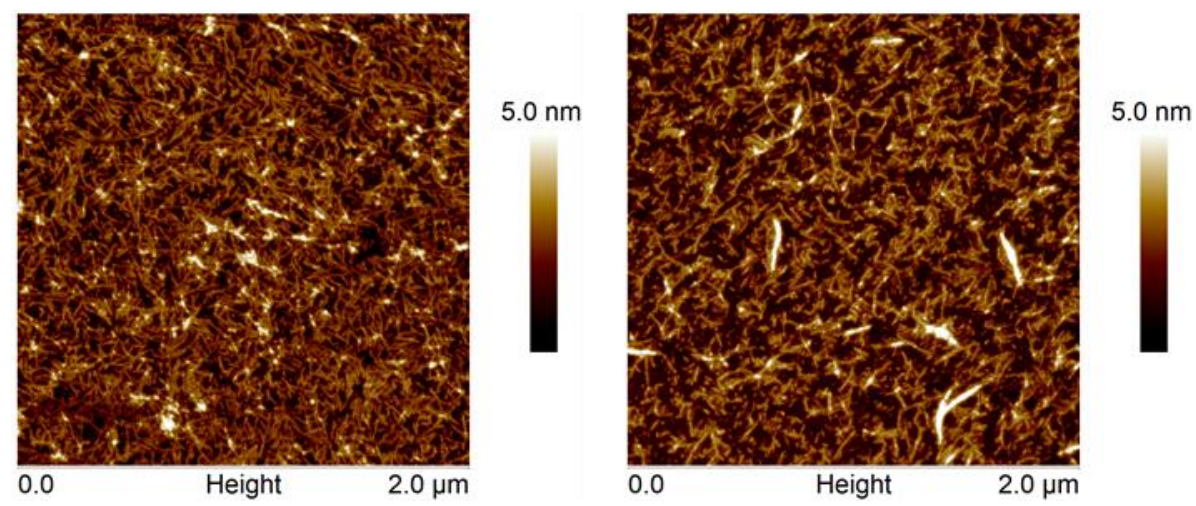

Figure S4 : Air AFM images of assemblies of $\mathrm{rA}_{15}$ with a) CA-C2- $\mathrm{NH}_{2}(48 \mathrm{mM})$ and b) $\mathrm{CA}-\mathrm{C} 4-\mathrm{NH}_{2}(22 \mathrm{mM})$ assemblies.

\begin{tabular}{lll}
\cline { 2 - 3 } & $\begin{array}{ll}\text { Height AFM } \\
(\mathrm{nm})^{*}\end{array}$ & $\begin{array}{l}\text { Number of } \\
\text { measurments } \\
N\end{array}$ \\
\hline \hline$-\boldsymbol{H}$ & & \\
\hline & $1.8 \pm 0.2$ & 81 \\
& $1.9 \pm 0.2$ & 60 \\
$-\mathbf{N H}_{2}$ & $1.9 \pm 0.1$ & 85 \\
& $2.0 \pm 0.2$ & 92 \\
& $2.3 \pm 0.3 *$ & 53 \\
\hline & $2.5 \pm 0.1$ & 128 \\
& $2.6 \pm 0.2$ & 67 \\
$-\mathbf{O H}$ & $2.4 \pm 0.1$ & 88 \\
& $2.3 \pm 0.1$ & 92 \\
& $2.4 \pm 0.1$ & 134
\end{tabular}

Table S1 : Height of individual fibers on $\mathrm{AFM}$ of dA ${ }_{30}$ and the associated CA-R from Figure S4. *denotes that this measurement was done on individual fibers. Uncertainty of one standard deviation. 

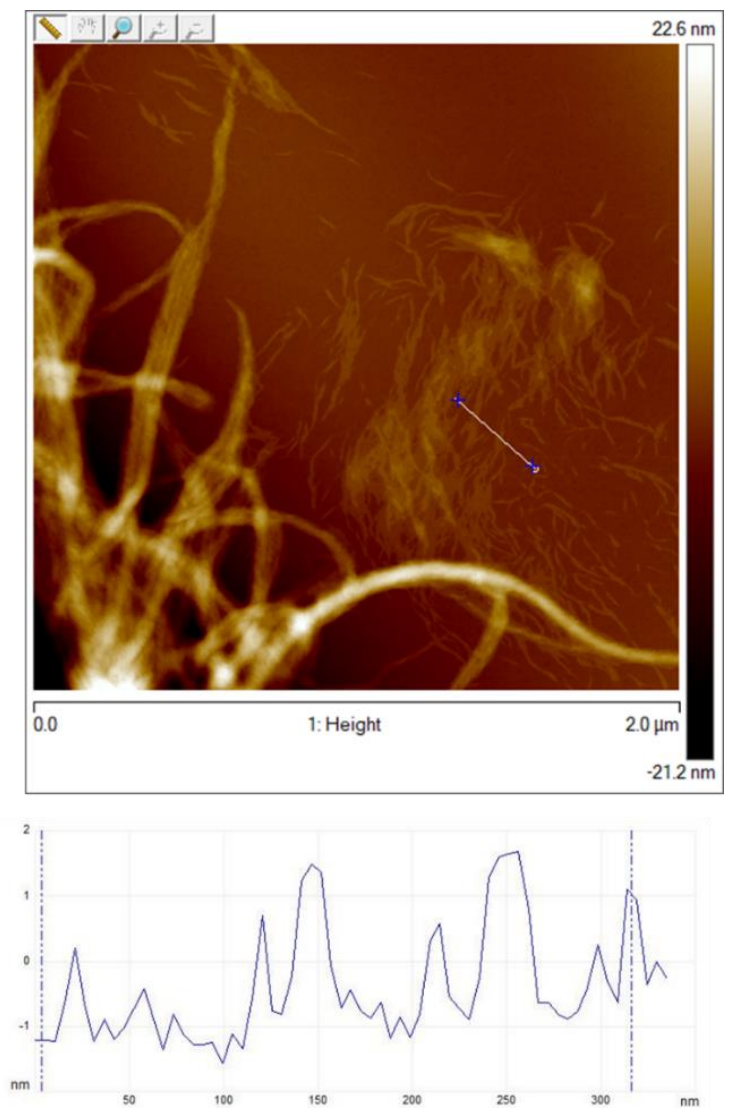

Figure S5 : AFM height measurement example of the individual fibers for $\mathrm{CAC} 6 \mathrm{NH}_{2}$.

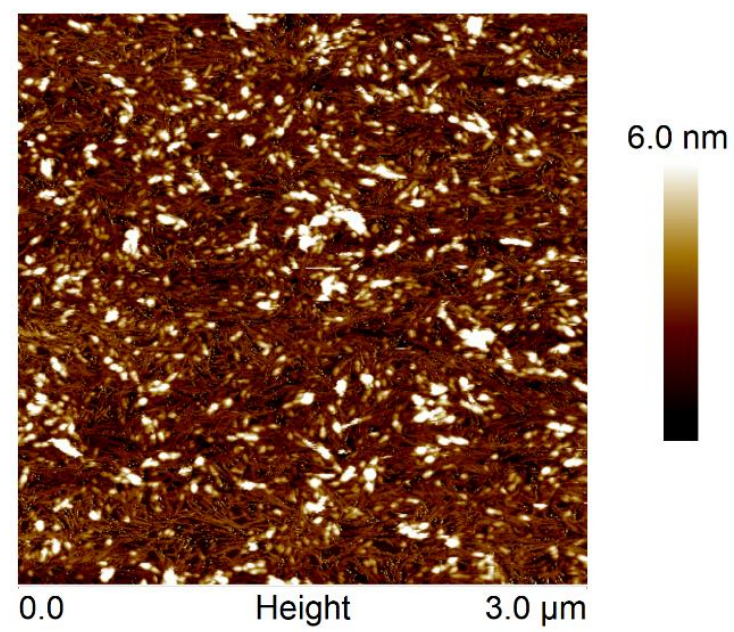

Figure S6 : Liquid AFM measurments of the assembly between $\mathrm{dA}_{30}(10 \mu \mathrm{M})$ and CA-C3-OH $(50 \mathrm{mM})$. The surface is Mica and the solvent is $1 \mathrm{xMESMg}$.

Figure S6 suggests the observed side-stacking of the alcohol series in Figure S3 is a drying phenomenon. The similar features of alcohols $\mathrm{C} 2 \mathrm{OH}$ to $\mathrm{C} 5 \mathrm{OH}$ indicate the similar intra/inter fiber interactions these derivatives have to one another, possibly a weak hydrophobic effect. $\mathrm{C} 6 \mathrm{OH}$ differs markedly from the series, having well separated individual fibers even in air AFM. For possible explanation why, see section VI. 


\section{Transient Equilibria experiment}

\section{i. $\quad$ Transient Equilibria (TREQ) Data Acquisition and Processing}

Samples of $100 \mu \mathrm{L}$ containing $25 \mu \mathrm{M}$ of $\mathrm{dA}_{15}$ in $1 \mathrm{xMESMg}$ buffer containing the variable amount of CA-R were prepared. The samples were heated to $65^{\circ} \mathrm{C}$ prior to experiments to degas oxygen bubbles, then added to the $1 \mathrm{~mm}$ cuvette. The sample was covered in $30 \mu \mathrm{L}$ of silicone oil to avoid evaporation. The instrumentation chamber was dried by flowing argon gas and adding drierite. First typical thermal annealing/melting scans containing both a cooling and heating trace were ran at the desired temperature scan rate for the TREQ experiment (typically $0.2-1^{\circ} \mathrm{C} / \mathrm{min}$ ) from assembly to disassembly. The raw absorbance data was then converted into a plot of fraction assembled vs. temperature, which can be done by determining adequate linear baselines at high and low temperature. The fraction assembled can then be calculated using the following equation where $\mathrm{L} 0_{\mathrm{T}}$ and $\mathrm{L}_{\mathrm{T}}$ are the values of the upper and lower baselines respectively and $\mathrm{Abs}_{\mathrm{T}}$ is the raw absorbance signal all evaluated at the same temperature T. ${ }^{1}$

$$
\theta_{T}=\frac{L 0_{T}-A b s_{T}}{L 0_{T}-L 1_{T}}
$$

The resulting graph provides upper and lower bounds to where the true equilibrium lies, thus scanning between these two curves will guarantee crossing of the equilibrium for each scan. Our spectrophotometer is able to run a total of 20 experiments in a single run, so we choose to scan between the heating and cooling traces every $10 \%$ assembled.

A TREQ experiment was then ran using the temperature ranges determined from the TH traces. After this data is collected it can be transformed in a similar way to a plot of free $\mathrm{dA}_{15}$ concentration vs temperature after selecting adequate upper and lower baselines. Where the free $\mathrm{dA}_{15}$ concentration at any given temperature $\left([\mathrm{M}]_{\mathrm{T}}\right)$ can be calculated from the fraction assembled $\left(\theta_{T}\right)$ and the total $\mathrm{dA}_{15}$ concentration $\left([\mathrm{M}]_{\mathrm{tot}}\right)$

$$
[M]_{T}=\theta_{T}[M]_{t o t}
$$

Now that the data has been transformed successfully the extrema need to be picked, as described in detail in our recent paper ${ }^{2}$ imply picking the maximum or minimum value of each trace is prone to error. Data smoothing is used to overcome this problem and was performed by fitting a $5^{\text {th }}$ order polynomial to either the upper or lower half of each experimental TE trace. Errors on picked extrema were found by re-running this analysis 500 times with resampled data and taking the standard deviation of all points found. ${ }^{3}$ These data points and errors represent points along the true equilibrium curve where the free $\mathrm{dA}_{15}$ concentration $\left(\left[d A_{15}\right]_{T}\right)$ is equal to the inverse of the association constant of fiber formation $\left(K_{e}\right)$. Thus each TREQ trace provided a point along the equilibrium curve which was used for further analysis. The assembly of derivatives $\mathrm{CAC} 5 \mathrm{OH}$ and $\mathrm{CAC} 6 \mathrm{OH}$ was not analyzed because their poor solubility and weaker assembly resulted in slowly precipitating the CA derivatives at the required low temperatures. Data for $\mathrm{CAC6} \mathrm{NH}_{2}$ also was noisy, as the large aggregates it forms (Main text subsection $\underline{\mathrm{CAC}_{\mathrm{NH}}} \underline{\underline{\mathrm{In}}} \underline{\underline{\mathrm{In}} \text { ter- }}$ fiber interactions) resulted in light scattering for the UV-vis and CD experiments. 

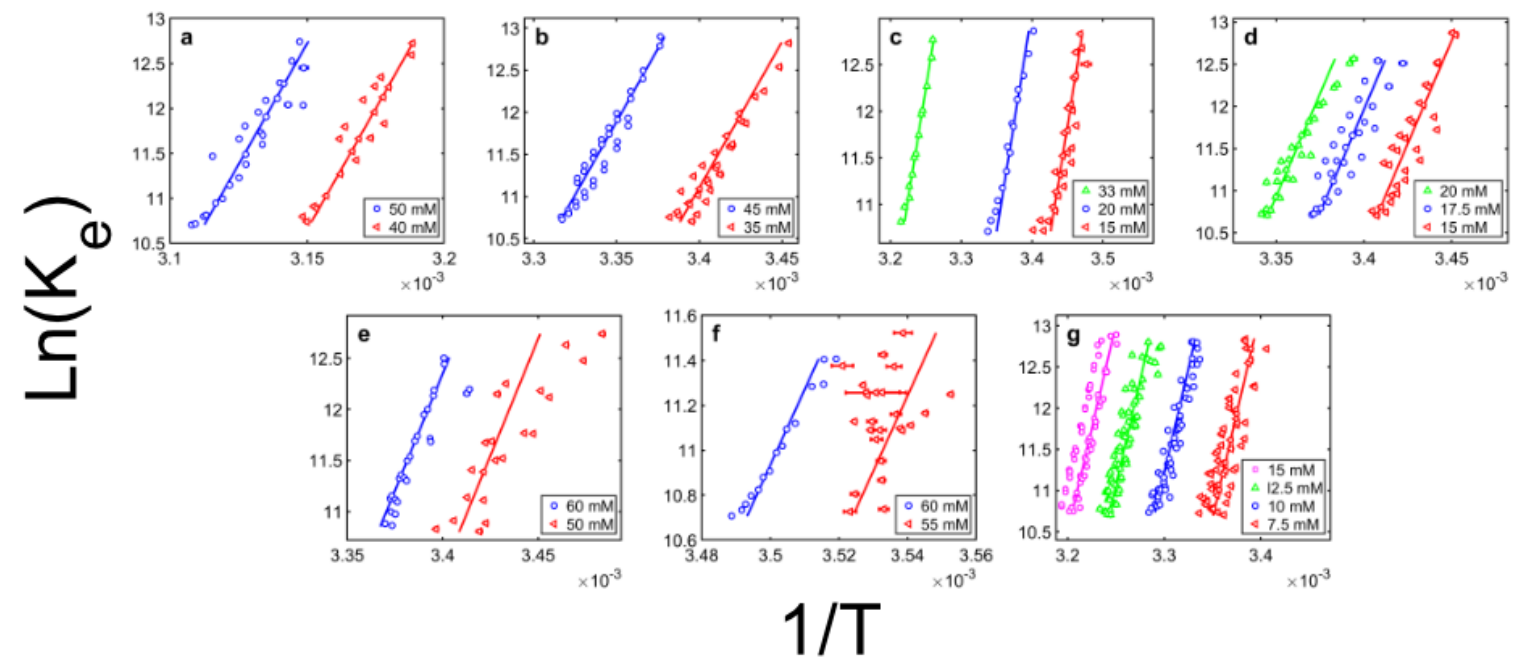

Figure S7: Van ' $t$ Hoff plot of TE data for different CA derivatives and at different concentrations. Coloured symbols represent experimental data from TE traces, solid-coloured lines represent a global fit of a constant stoichiometry model. Thermodynamic parameters can be found in Table S2 and Table 1. Experimental error bars are plotted in both the horizontal and vertical direction. Derivatives are: a) $\mathrm{CAC} 2 \mathrm{NH} 2, \mathbf{b}) \mathrm{CAC} 3 \mathrm{NH} 2, \mathbf{c}) \mathrm{CAC} 4 \mathrm{NH} 2$, d) CAC5NH2, e) $\mathrm{CAC} 3 \mathrm{OH}, \mathbf{f}$ ) $\mathrm{CAC} 4 \mathrm{OH}, \mathbf{g}) \mathrm{CA}$.

\section{ii. Thermodynamic analysis}

The co-assembly of polyA-CA fibers was modelled following a constant stoichiometry model ${ }^{2}$ which can be described as an addition of a single $\mathrm{dA}_{15}$ strand $\left(M_{1}\right)$ to the end of a growing fiber $\left(M_{n}\right)$ with $c$ CA molecules (or derivatives) i.e.

$$
M_{n}+M_{1}+c C A \stackrel{K_{e}}{\leftrightarrow} M_{n+1}
$$

The full equilibrium association constant for the process is given by

$$
K_{(T)}^{\circ}=\frac{\left[M_{n+1}\right]}{\left[M_{n}\right]\left[M_{1}\right][C A]^{c}}
$$

And the apparent association constant $K_{e}$ can be described as

$$
K_{e}=\left.\frac{\left[M_{n+1}\right]}{\left[M_{n}\right]\left[M_{1}\right]}\right|_{[C A]}=K_{(T)}^{\circ}[C A]^{c}
$$

Where the temperature of the standard equilibrium constant $\left(K_{(T)}\right)$ described by

$$
K_{(T)}^{\circ}=\exp \left(-\frac{(\Delta H-T \Delta S)}{R T}\right)
$$


For each cyanuric acid concentration, a thermodynamic curve was calculated according to Equation 7 in a temperature range from $10-50^{\circ} \mathrm{C}$ with a resolution of $0.01^{\circ} \mathrm{C}$. Each model's parameters were optimized using total least squares regression. Distance was minimized according to

$$
\chi^{2}=\sum_{j=1}^{N} \sqrt{\left(\frac{\Delta_{\ln \left(K_{e(j)}\right)}}{\sigma_{\ln \left(K_{e(j)}\right)}}\right)^{2}+\left(\frac{\Delta_{1}}{\frac{T_{(j)}}{\sigma_{1}}}\right)^{2}}
$$

Where $\Delta_{\ln \left(K_{e(j)}\right)}$ is the vertical distance of the $j^{\text {th }}$ experimental data point to the point on the calculated curve which minimized the horizontal distance. $\frac{1}{T_{(j)}}$ is the horizontal distance of the $j^{\text {th }}$ experimental point to the point on the calculated curve which minimized the vertical distance. $\sigma_{\ln \left(K_{e(j)}\right)}$ and $\sigma_{\frac{1}{T}(j)}$ are the experimental errors in the vertical and horizontal dimensions respectively. Errors for fitted parameters were calculated by optimizing the parameters to 500 sets of resampled data and taking the standard deviation of each parameter. ${ }^{3}$

\begin{tabular}{|c|c|c|c|c|}
\hline Derivative & $\Delta \mathbf{H}$ & $-T_{10^{\circ} \mathrm{C}} \Delta S$ & $\Delta \mathbf{G}_{10^{\circ} \mathrm{C}}$ & Stoichiometry \\
\hline $\mathrm{CAC} 2 \mathrm{NH}_{2}$ & $-48 \pm 3$ & $34 \pm 3$ & $-15.6 \pm 0.4$ & $9.2 \pm 0.6$ \\
\hline $\mathrm{CAC}_{3} \mathrm{NH}_{2}$ & $-28.7 \pm 0.9$ & $17.3 \pm 0.8$ & $-11.5 \pm 0.2$ & $10.2 \pm 0.6$ \\
\hline $\mathrm{CAC}_{4 \mathrm{NH}_{2}}$ & $-31.5 \pm 0.2$ & $18.4 \pm 0.2$ & $-13.1 \pm 0.1$ & $11.3 \pm 0.5$ \\
\hline $\mathrm{CAC} \mathrm{NH}_{2}$ & $-39 \pm 1$ & $26 \pm 1$ & $-13.7 \pm 0.3$ & $10.4 \pm 0.9$ \\
\hline $\mathrm{CAC} 3 \mathrm{OH}$ & $-35 \pm 4$ & $24 \pm 3$ & $-10.8 \pm 0.3$ & $10 \pm 1$ \\
\hline $\mathrm{CAC} 4 \mathrm{OH}$ & $-27 \pm 4$ & $18 \pm 4$ & $-9.7 \pm 0.6$ & $9 \pm 2$ \\
\hline $\mathrm{CA}$ & $-39.4 \pm 0.4$ & $23.4 \pm 0.3$ & $-16.0 \pm 0.1$ & $10.4 \pm 0.4$ \\
\hline
\end{tabular}

Table S2: Thermodynamic parameters obtained from direct fitting of van 't Hoff plot of each CA derivative. $\Delta \mathrm{H},-\mathrm{T}_{10^{\circ} \mathrm{C}} \Delta \mathrm{S}$, and $\Delta \mathrm{G}_{10^{\circ} \mathrm{C}}$, are given in $\mathrm{kJ} \mathrm{mol}^{-1}$. 


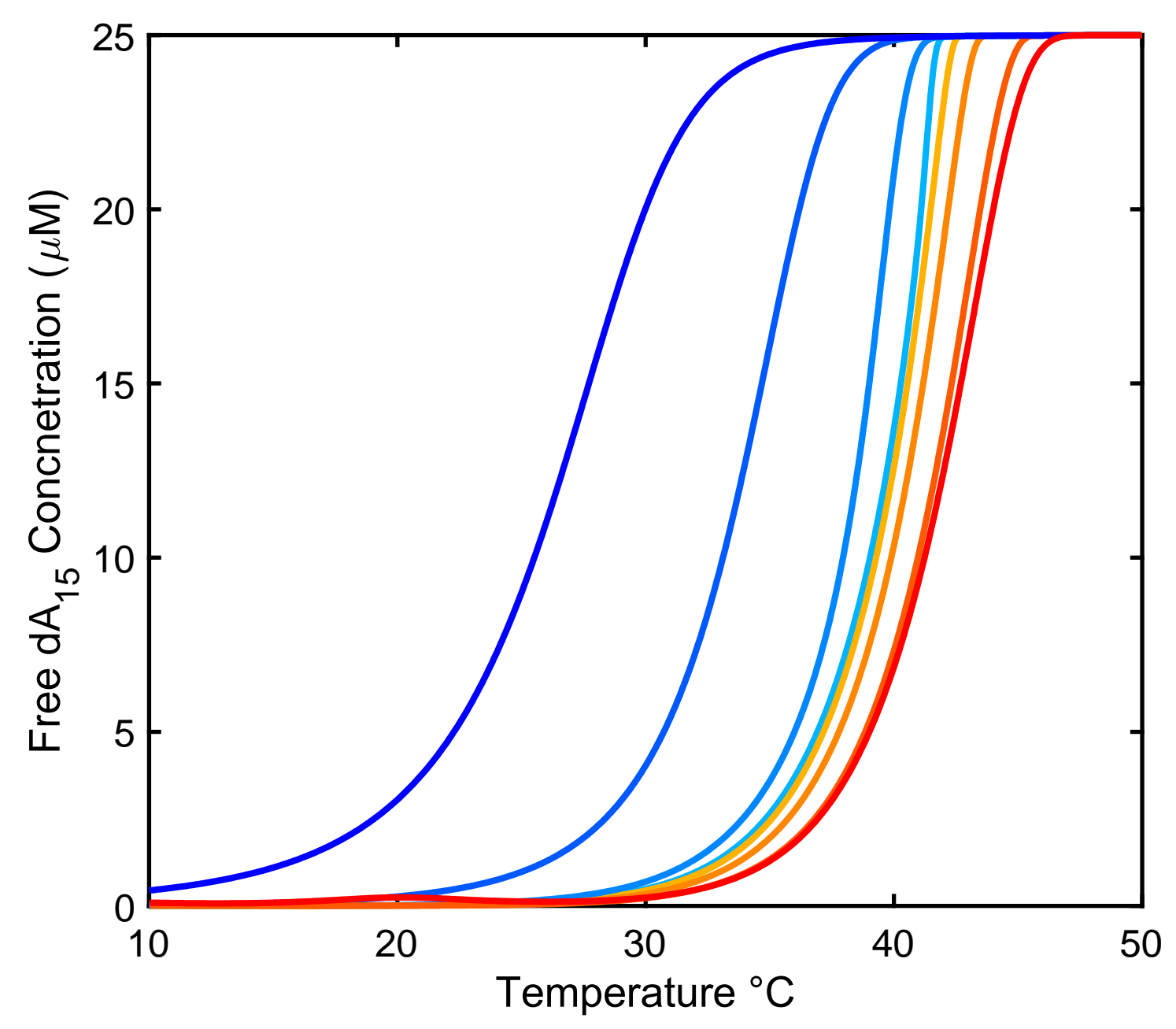

Figure S8: Simulated thermal hysteresis traces of $\mathrm{dA}_{15}(25 \mu \mathrm{M})$ and $\mathrm{CA}(15 \mathrm{mM})$ for varying scan rates $(1,0.1,0.01$, and $0.001^{\circ} \mathrm{C} / \mathrm{min}$ ). Heating and cooling traces are shown as a red-orange and blue-cyan gradient respectively, with red/blue corresponding to a scan rate of $1{ }^{\circ} \mathrm{C} / \mathrm{min}$ and orange/cyan corresponding to a scan rate of $0.001^{\circ} \mathrm{C} / \mathrm{min}$. The total time for each thermal hysteresis trace is 80 minutes for $1^{\circ} \mathrm{C} / \mathrm{min}, 13$ hours for $0.1^{\circ} \mathrm{C} / \mathrm{min}, 5.5$ days for $0.01^{\circ} \mathrm{C} / \mathrm{min}$ and 55 days for $0.001^{\circ} \mathrm{C} / \mathrm{min}$.

\section{iii. Calculation of TREQ-derived $[C A-R]_{c r i t}$}

The TREQ derived thermodynamic parameters $\left(\Delta \mathrm{H}_{e}, \Delta \mathrm{S}_{\mathrm{e}}\right.$, and stoichiometry, $\left.\mathrm{c}\right)$ can be used to calculate the theoretical concentration of $\mathrm{CA}$ (or derivatives) where assembly will begin (i.e. [CA $]_{\text {crit }}$ ). This is done by calculating the concentration of $\mathrm{CA}$ at which $K_{e}$ is equal to the inverse of the total concentration of $\mathrm{dA}_{15}$ i.e.

$$
K_{e}=\frac{1}{\left[d A_{15}\right]_{\text {total }}}
$$

Where the apparent association constant $K_{e}$ can be described using equations $S 6$ and $S 7$ to give 


$$
\frac{1}{\left[d A_{15}\right]_{\text {total }}}=\exp \left(-\frac{(\Delta H-T \Delta S)}{R T}\right)[C A]_{\text {crit }}^{c}
$$

Which can then be rearranged in terms of the concentration of CA to give

$$
[C A]_{\text {crit }}=\left(\frac{1}{\exp \left(-\frac{(\Delta H-T \Delta S)}{R T}\right)\left[d A_{15}\right]_{\text {total }}}\right)^{\frac{1}{c}}
$$

These values were evaluated at $T=10^{\circ} \mathrm{C}$, and the errors were found by calculating $[\mathrm{CA}]_{\text {crit }}$ for each set of parameters found by

\begin{tabular}{|c|c|c|c|}
\hline & & $\begin{array}{l}{[\mathbf{C A}-\mathbf{R}]_{\mathrm{critical}}} \\
\text { Experimental }(m M)^{\ddagger}\end{array}$ & Calculated $(m M)^{\times}$ \\
\hline$-H$ & CO & $2-3$ & $3.14 \pm 0.04$ \\
\hline \multirow{5}{*}{$-\mathrm{NH}_{2}$} & $\mathrm{C2}$ & $5-6$ & $4.4 \pm 0.6$ \\
\hline & C3 & $15-20$ & $21.2 \pm 0.4$ \\
\hline & $\mathrm{C4}$ & $6-7$ & $9.87 \pm 0.09$ \\
\hline & C5 & $6-7$ & $8.2 \pm 0.2$ \\
\hline & C6 & $6-7$ & \\
\hline \multirow{5}{*}{$-\mathrm{OH}$} & C2 & $25-30$ & \\
\hline & C3 & $20-25$ & $29 \pm 2$ \\
\hline & $\mathrm{C4}$ & $45-50$ & $52 \pm 1$ \\
\hline & C5 & $50-60$ & \\
\hline & C6 & $20-25$ & \\
\hline
\end{tabular}
the bootstrapping approached described above and taking the standard deviation of calculated values (Table S3).

Table S3 : Comparison between the experimental values of [CA-R $]_{\text {crit }}$ obtained through circular dichroism assembly curves and calculated values from the thermodynamic parameters obtained through TREQ experiments. 


\section{Computational Methods}

\section{i. General Computational}

The structure and noncovalent interactions of the DNA assemblies with cyanuric acid derivatives were explored using molecular dynamics simulation. For each of the alcohol and amino systems, we constructed two initial DNA triplex model systems: one in the hexameric rosette configuration for the bases and the syn conformation for the DNA backbone and the other in the helicene configuration for the bases and the anti conformation for the DNA backbone. The DNA strands consist of 15 nucleotides. The initial models were constructed using the proto-Nucleic Acid Builder program (version 1.5) 4 and custom scripts. To clean up the initial models, they were minimized in implicit solvent using the generalized Born model ${ }^{5-7}$ as implemented in the AmberTools package (version 20). ${ }^{8}$ The minimized structures were then solvated in water boxes with a padding distance of 16 Angstroms and with neutralizing sodium or chlorine ions using the AmberTools package. The MD simulations were performed using the OpenMM package (version 7.5). ${ }^{9}$ Each simulation was replicated twice and the findings of the simulations are similar. The simulation protocol is similar to that used previously. ${ }^{10}$ Briefly, the systems were minimized and then heated for $200 \mathrm{ps}$ at constant volume and temperature (300 K) using the Langevin integrator with a friction constant of $1.0 \mathrm{ss}^{-1}$ and a time step of $2.0 \mathrm{fs}$. Next, the systems were equilibrated at 1 bar using a Monte Carlo barostat for $100 \mathrm{~ns}$. Lastly, the production simulations were run for $400 \mathrm{~ns}$ at constant temperature and pressure with snapshots saved every $10 \mathrm{ps}$. Bond lengths involving hydrogen atoms were constrained. ${ }^{11}$ Particle mesh Ewald summation was used for treating long-range electrostatic interactions. Nonbonded interactions were cut off at 12 Angstroms and a switching function was applied at 10 Angstroms. The AMBER force field for DNA (OL15) ${ }^{12}$ the TIP3P water model ${ }^{13}$, and the Joung and Cheatham model for the counter ions ${ }^{14}$ were used. AMBER atom types were assigned to the cyanuric acid derivatives and missing force field parameters were assigned using reported parameters for modified nucleotides. ${ }^{15}$ Restrained electrostatic potential (RESP) model ${ }^{16} \mathrm{charges}$ were computed using the RESP plugin (version 1.0) ${ }^{17}$ for the Psi4 package. ${ }^{18}$ The 3DNA program (version 2.4) ${ }^{19}$ was used for the structural analysis of the DNA strands in the assemblies. The PYTRAJ package (version 2.0$)^{20}$ was used for the hydrogenbonding analysis with default options. A custom script was written to analyze the radial distributions of the tails that utilized the pseudocode available in ref. 21 for fitting points to a cylinder. The VMD program (version 1.9) was used for visualization. ${ }^{22}$

\section{ii. Choice of anti-helicene conformation}

Different helicene models have been proposed.${ }^{10}$ From these, the two most coherent with previously published data, the syn and the anti parallel triplex, were simulated with all the CA-R library. ${ }^{23-25}$ Briefly, the DNA backbone conformation depends on the glycosidic torsion $\chi$, which has two accessible states, anti and syn, that are separated by a high energy barrier. The anti conformation is generally preferred but the syn conformation is also possible for the purine nucleobases ${ }^{26-27}$. In both these models, the cyanuric acid sidechains display significant interaction with the (negatively charged) phosphate groups in DNA. Owing to the different geometries of the anti and syn conformation, the frequency of interaction is not identical between the conformers, of which the largest variation is with the $\mathrm{CAC} 2 \mathrm{NH}_{2}$ derivative. The syn conformation predicts very poor phosphate binding for this derivative. Since thermodynamic experiment show this derivative to be the most stabilized, and that the driver for this stability is enthalpic owing to its charged amino sidechain, we suggest the syn configuration is not the one adopted experimentally. For that reason, the rest of our analysis will focus on the anti conformer. 


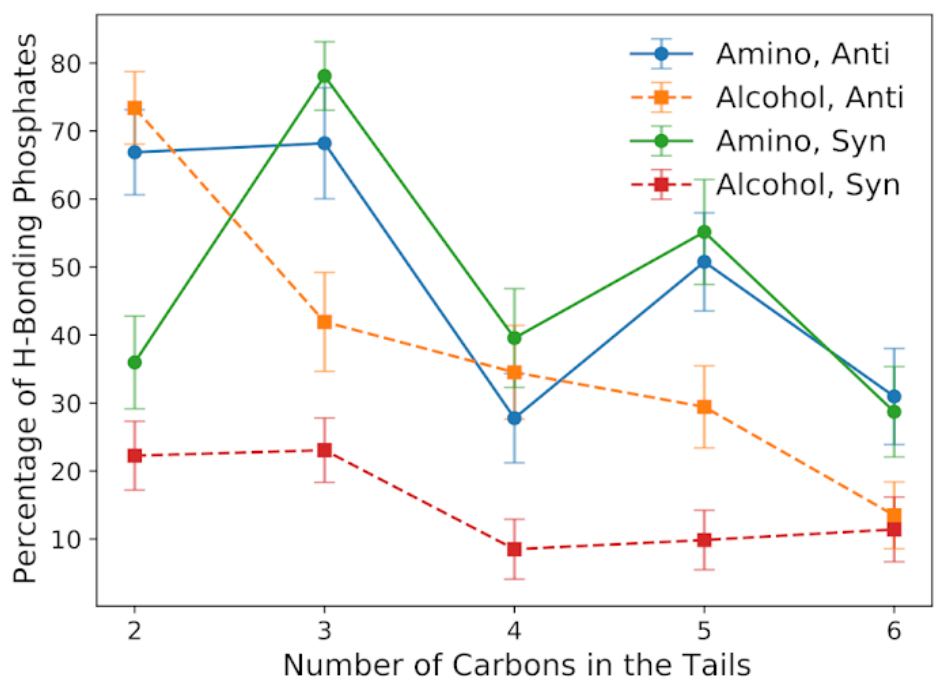

Figure S9: The average percentage of phosphate groups in DNA that form hydrogen bonds with the amino or alcohol groups of the various cyanuric acid derivatives for either the anti or syn helicene model. The error bars show one standard deviation over the 500 ns trajectory 
a) $\mathrm{CAC} 2 \mathrm{NH} 2$
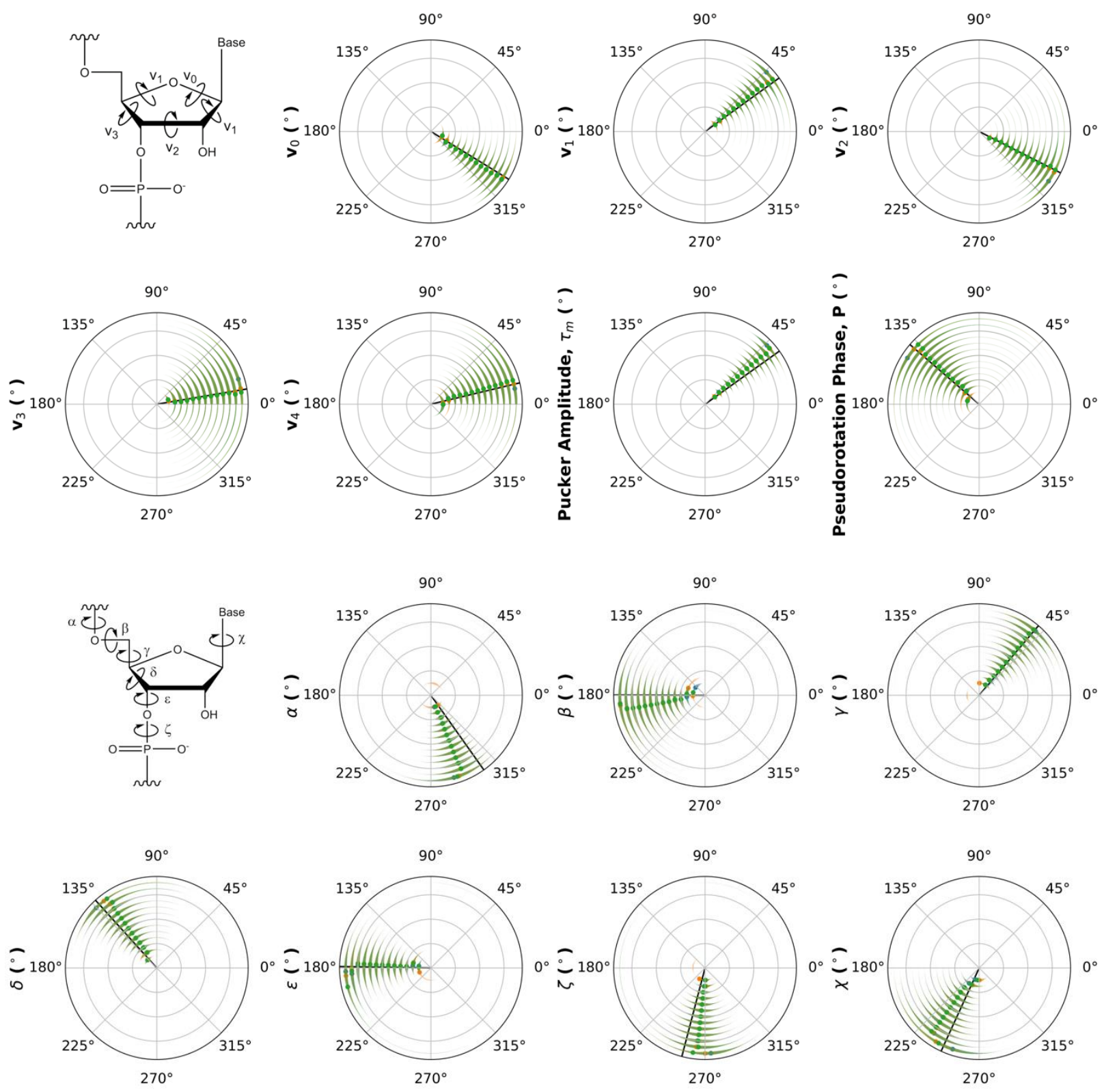
b) $\mathrm{CAC} 3 \mathrm{NH} 2$ 

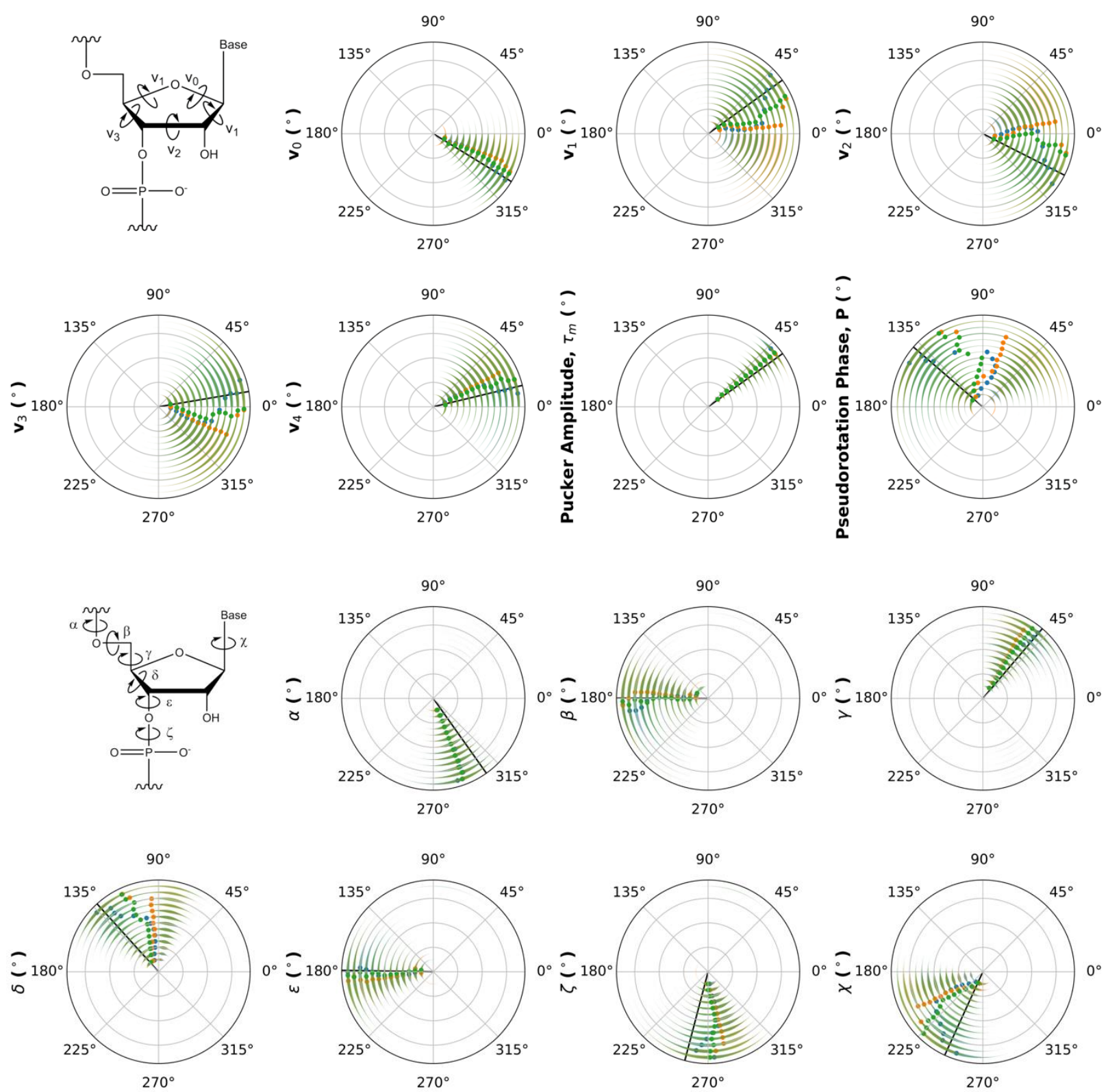

\section{c) $\mathrm{CAC} 4 \mathrm{NH} 2$}



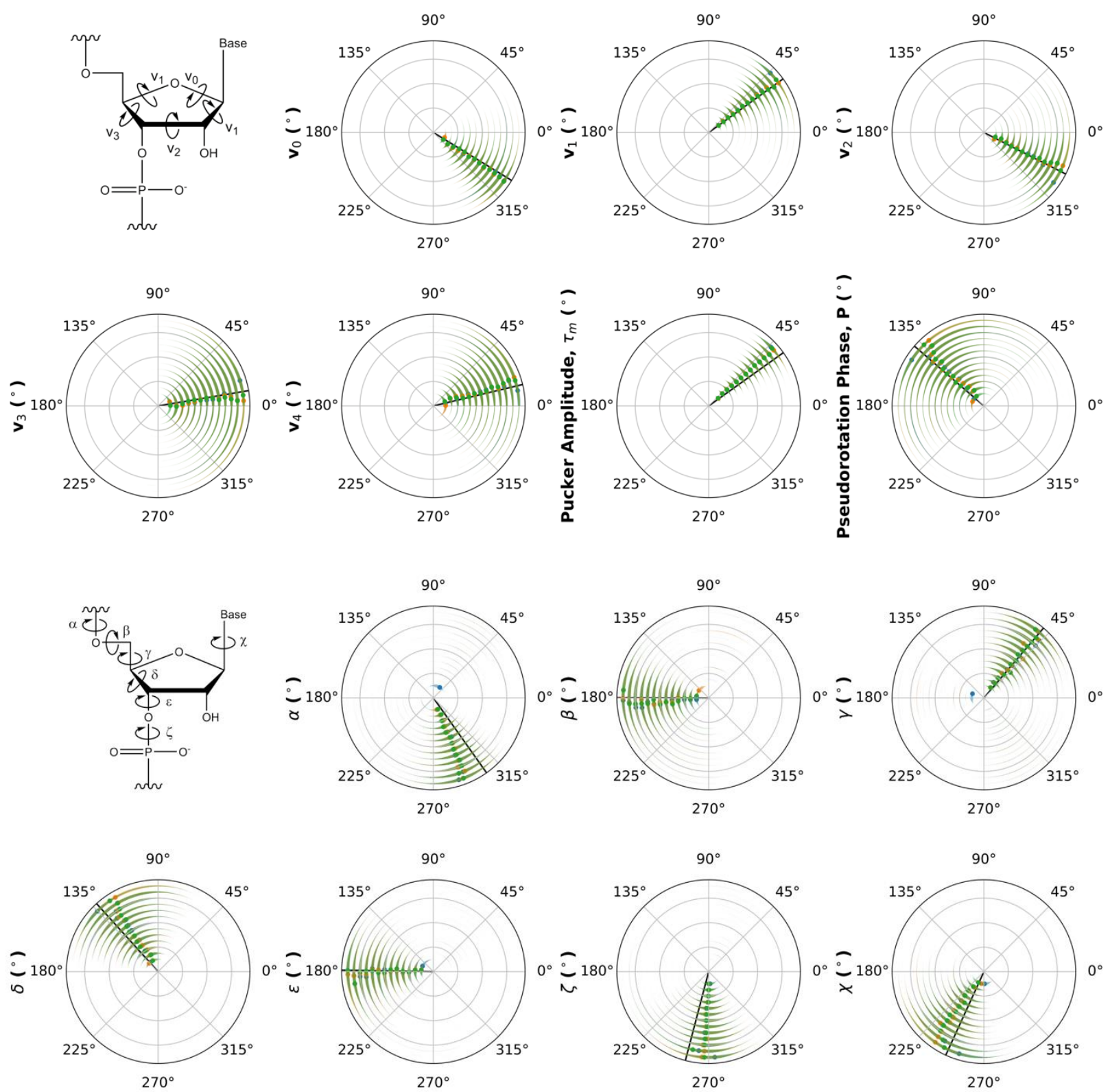

d) $\mathrm{CAC} 5 \mathrm{NH} 2$ 

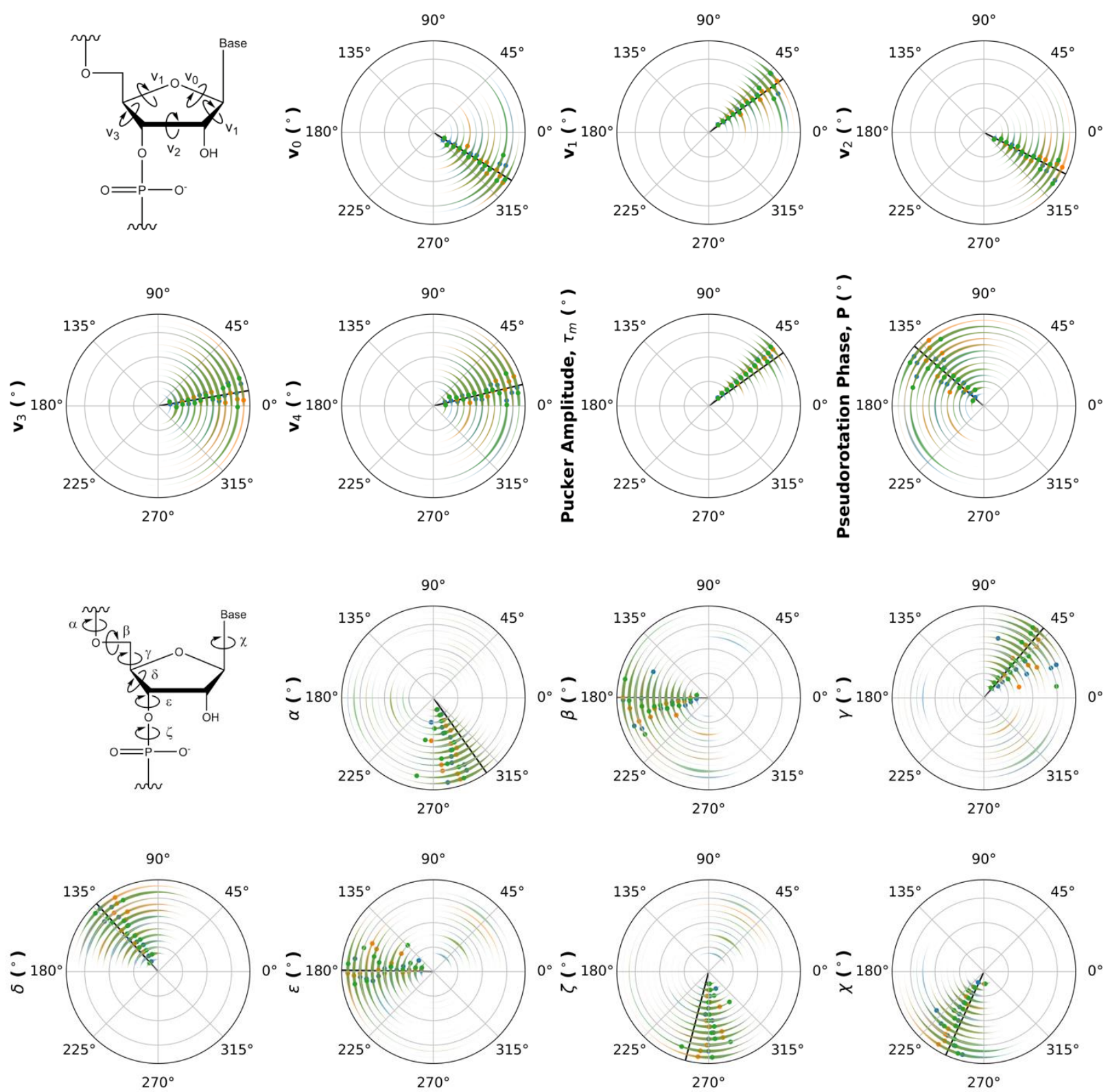

e) $\mathrm{CAC} 6 \mathrm{NH} 2$ 

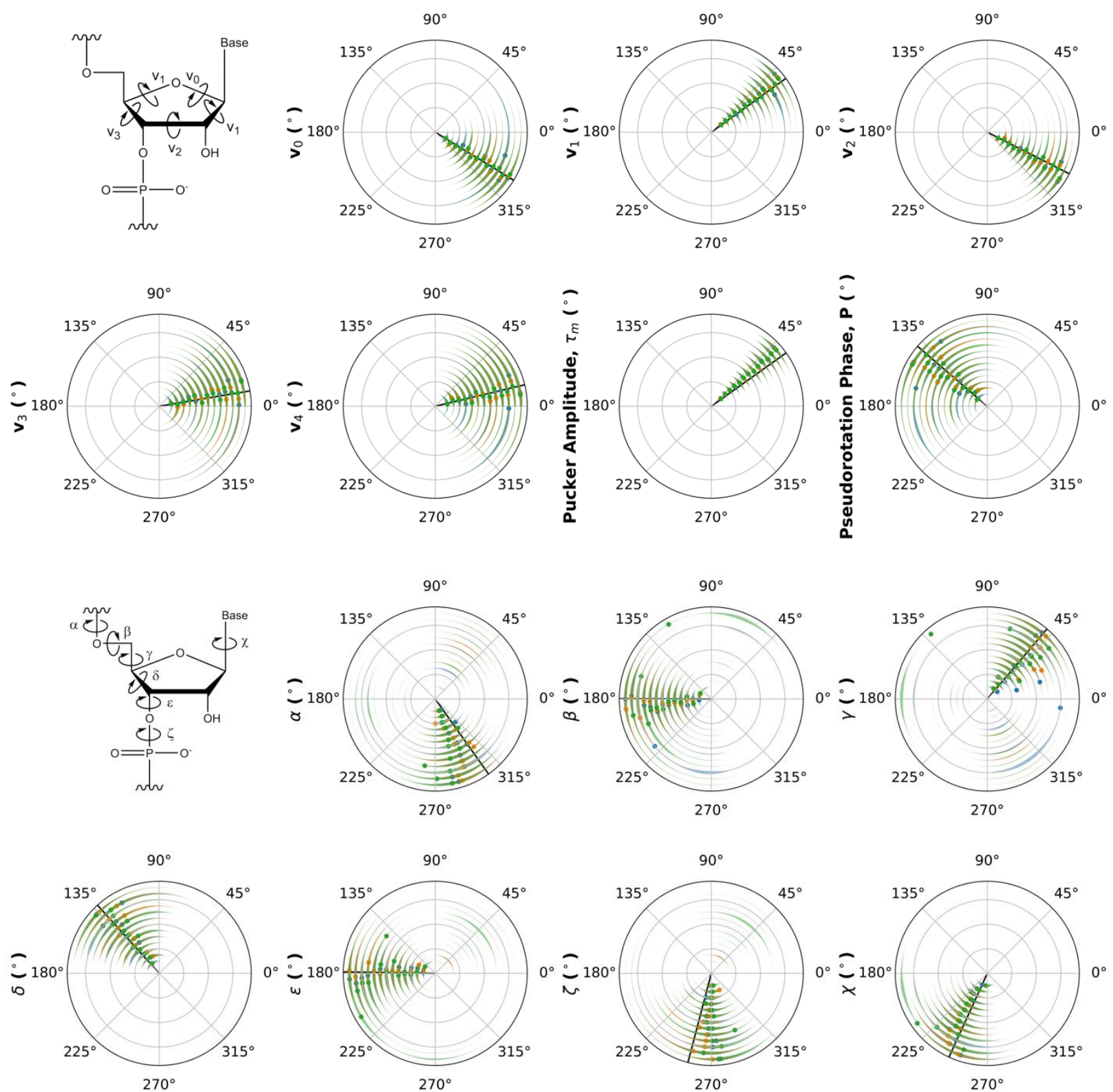

Figure S10: DNA sugar parameters and DNA backbone parameters from the MD simulations for the amino derivatives. The three colors (blue, orange, and green) correspond to the three DNA strands in the adenine-CA assemblies. The dots represent the mean and the smear represent the distribution. The overlap between the three colors shows the uniformity of the structure of the assembly. The black line shows the structure of the canonical B-form of DNA.

\section{iii. Secondary phosphate binding of $\mathrm{CAC} 5 \mathrm{NH}_{2}$}

CAC5NH $\mathrm{N}_{2}$ is the first CA-R able to reach a distal phosphate binding site, located on the other strand it's CA core is connected to (Figure S9). However, that distal phosphate only provides $18 \%$ of all hydrogen bonding interactions. The bulk of the phosphate binding of $\mathrm{CAC} 5 \mathrm{NH}_{2}$ is with the same proximal phosphate binding site as the much shorter $\mathrm{CAC} 2 \mathrm{NH}_{2}$, as mentioned in the main text. To bind this distal phosphate, the latter must be in the same outward pointing conformation as mentioned in the main text. 


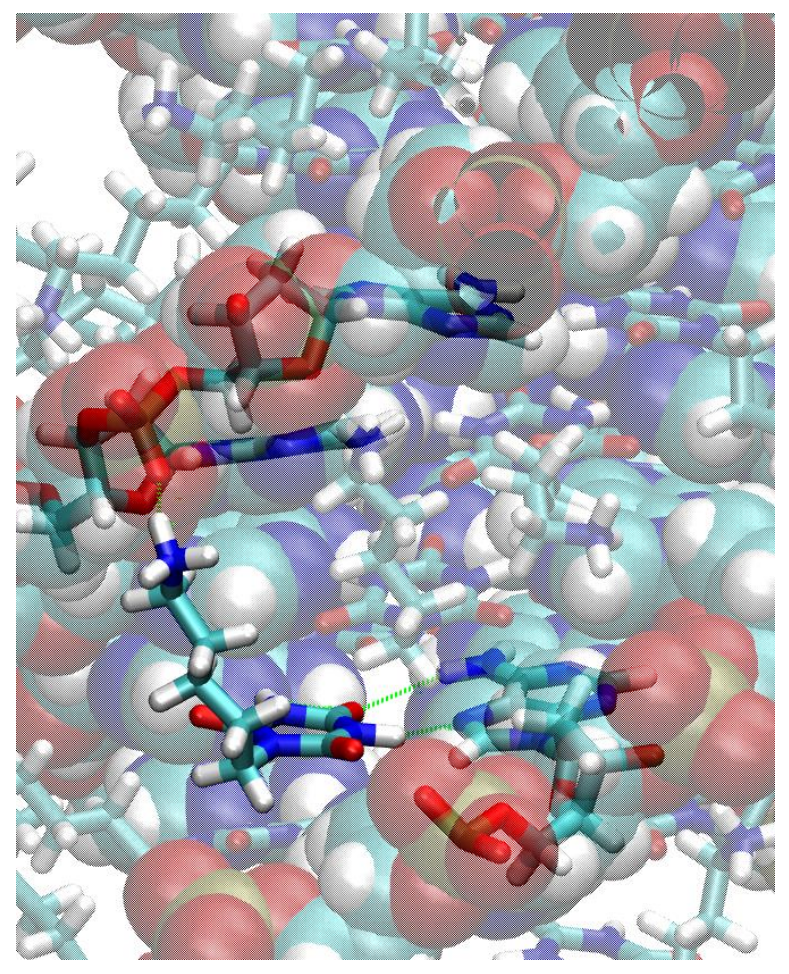

Figure S1 1: Representative example of $\mathrm{CAC}_{5} \mathrm{NH}_{2}$ binding a distal phosphate from a MD snapshot. For clarity, the hydrogen bonds are highlighted in green and the helicene structure is faded.

\section{iv. Adenine $\mathrm{H}$-bond of $\mathrm{CAC6OH}$}

Due to its relatively low critical concentration (Figure 2c) and its change in fiber conformation on AFM (Figure S3), the CAC6OH derivative stands out experimentally. It is thus interesting to notice it stands out computationally as well. In the radial extent analysis (Figure $5 b$ ), it is the only derivative to have a multimodal distribution. The different modes of this distribution correspond to free tails versus tightly sheltered tails in the groove of the dA/CA-R fibers. The tails of this derivative tend to shelter themselves more tightly in the groove, an indication of the growing strength of the hydrophobic effect. This tight conformation is supplemented by a specific hydrogen bonding interaction between the terminal alcohol and the N3 heterocyclic nitrogen on the adenine base (Figure S10), corresponding to the very lowest radial extent mode. It is possible the combination of the hydrophobic effect and this specific hydrogen bond explain why the behavior of the $\mathrm{CAC} 6 \mathrm{OH}$ derivative breaks the experimental trends of the alcohols, and it suggests further elongation of the tail could exacerbate those effects. 


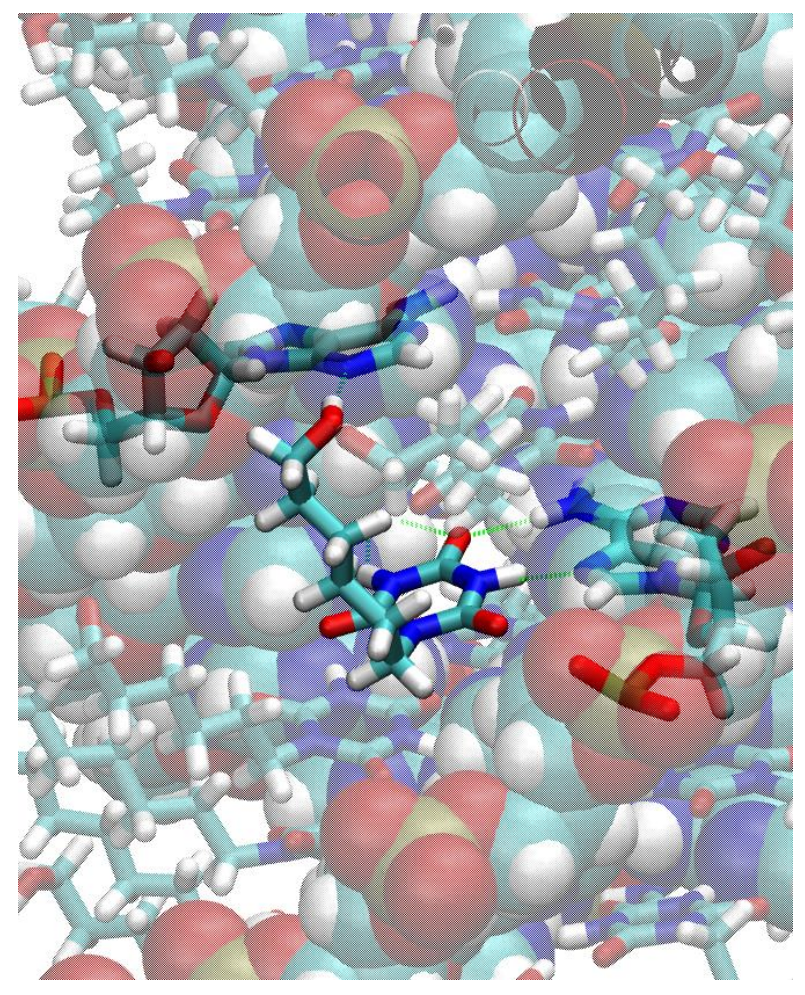

Figure S12: Representative example of CAC6OH binding the N3 nitrogen of the adenine from a MD snapshot. For clarity, the hydrogen bonds are highlighted in green and the helicene structure is faded.

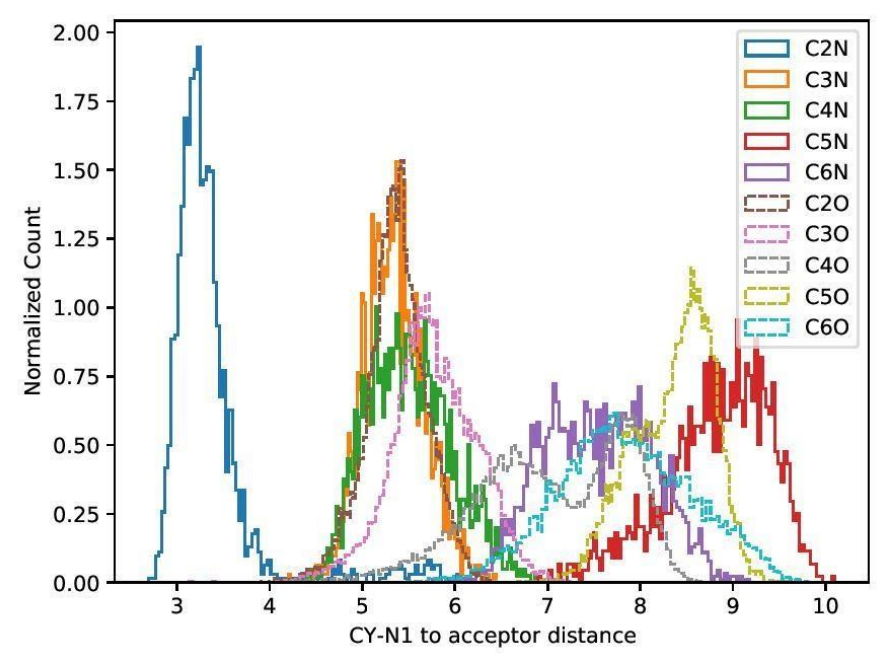

Figure S13: Distance from CA core to functional group when having a hydrogen bond with the DNA backbone phosphate. 


\section{Synthesis}

i. Synthesis of alcohol substituted cyanurates

The synthesis was performed in three steps following the pathway presented in Scheme 1.28-29

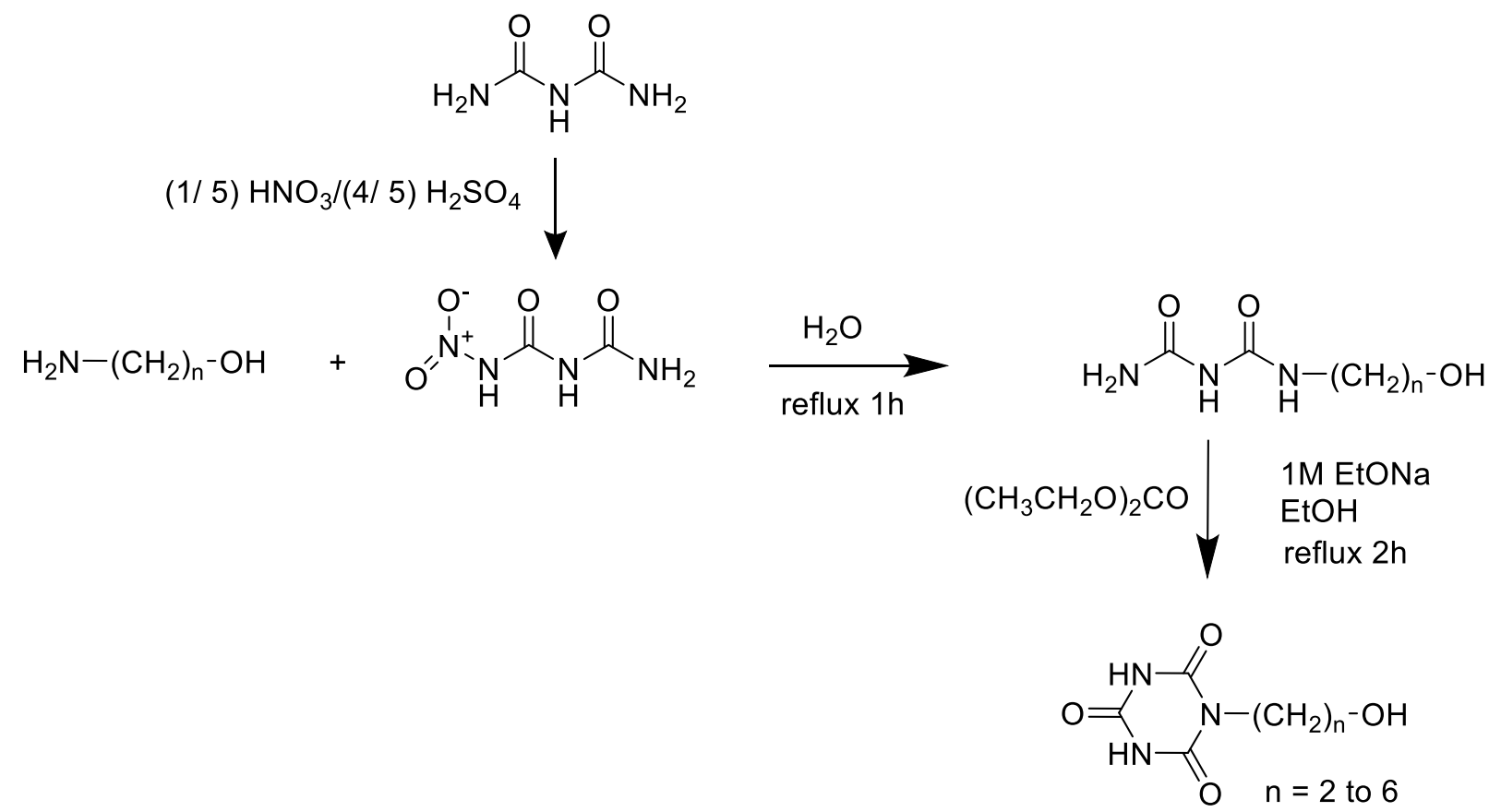

Scheme 1: General procedure for the synthesis of alcohol substituted cyanurates.

a) Procedure for the synthesis of nitrobiuret

$25.4 \mathrm{~g}$ of biuret $(0.17 \mathrm{mmol})$ was slowly added to an ice cooled mixture of $125 \mathrm{~mL}$ of concentrated $\mathrm{H}_{2} \mathrm{SO}_{4}$ and $33 \mathrm{~mL}$ of concentrated nitric acid. After all the biuret had dissolved, the clear solution was added to icy water and the resulting precipitate was filtered and washed trice with $50 \mathrm{~mL}$ of cold water. This white precipitate was recrystallized with water kept at $70{ }^{\circ} \mathrm{C}$ to avoid excessive decomposition. The recrystallized white powder was washed trice with $50 \mathrm{~mL}$ of cold water and twice with 15 $\mathrm{mL}$ of cold EtOH. 
b) General procedure for the synthesis of monosubstituted biuret ( $n=2$ to 6 )

Nitrobiuret (10 mmol, 1 eq.) and n-hydroxy-1-aminoalkane (1 eq.) were brought to reflux in $10 \mathrm{~mL} \mathrm{H}_{2} \mathrm{O}$ for $1 \mathrm{~h}$. The solution was then evaporated under reduced atmosphere and the dried white powder was recrystallized from EtOH. The products were characterized by HRMS, ${ }^{1} \mathrm{H}$ and ${ }^{13} \mathrm{C}$ NMR.

C2OH-biuret : Yield 27\% HRESI-MS C4H9N3NaO3 calc: 170.0536 found: 170.0531

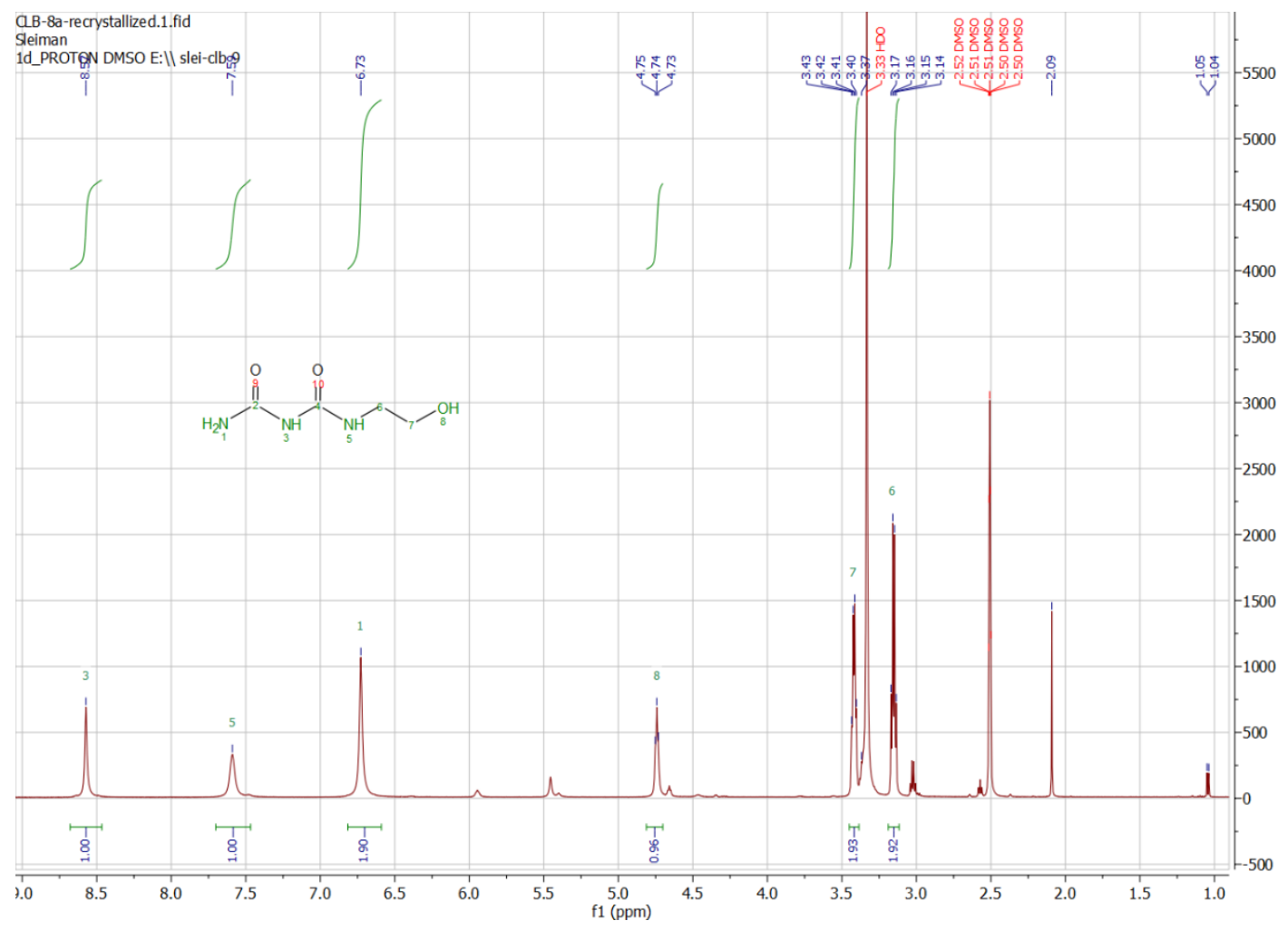

${ }^{1} \mathrm{H}$ NMR $\left(500 \mathrm{MHz}\right.$, DMSO-d $\left.d_{6}\right) \delta 8.57(\mathrm{~s}, 1 \mathrm{H}), 7.59(\mathrm{~s}, 1 \mathrm{H}), 6.73(\mathrm{~s}, 2 \mathrm{H}), 4.74(\mathrm{t}, J=5.1 \mathrm{~Hz}, 1 \mathrm{H}), 3.42(\mathrm{q}, J=5.3 \mathrm{~Hz}, 2 \mathrm{H})$, $3.15(\mathrm{q}, J=5.7 \mathrm{~Hz}, 2 \mathrm{H})$. 


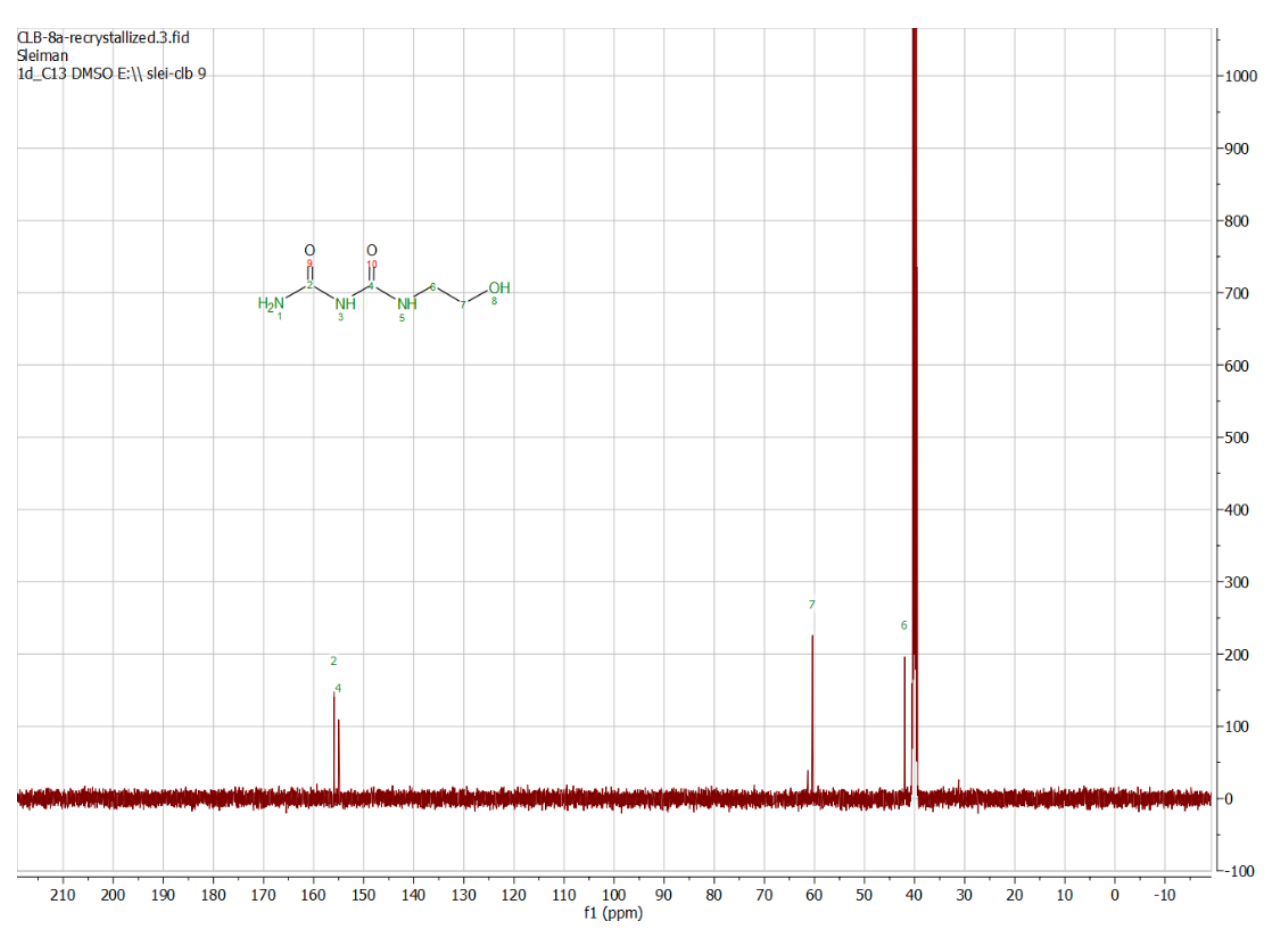

${ }^{13} \mathrm{C}$ NMR $\left(126 \mathrm{MHz}, \mathrm{DMSO}-d_{6}\right) \delta 155.93,155.00,60.39,41.98$.

C3OH-biuret : Yield 36\% HRESI-MS C5H7N3NaO4 calc: 196.0329 found: 196.0329

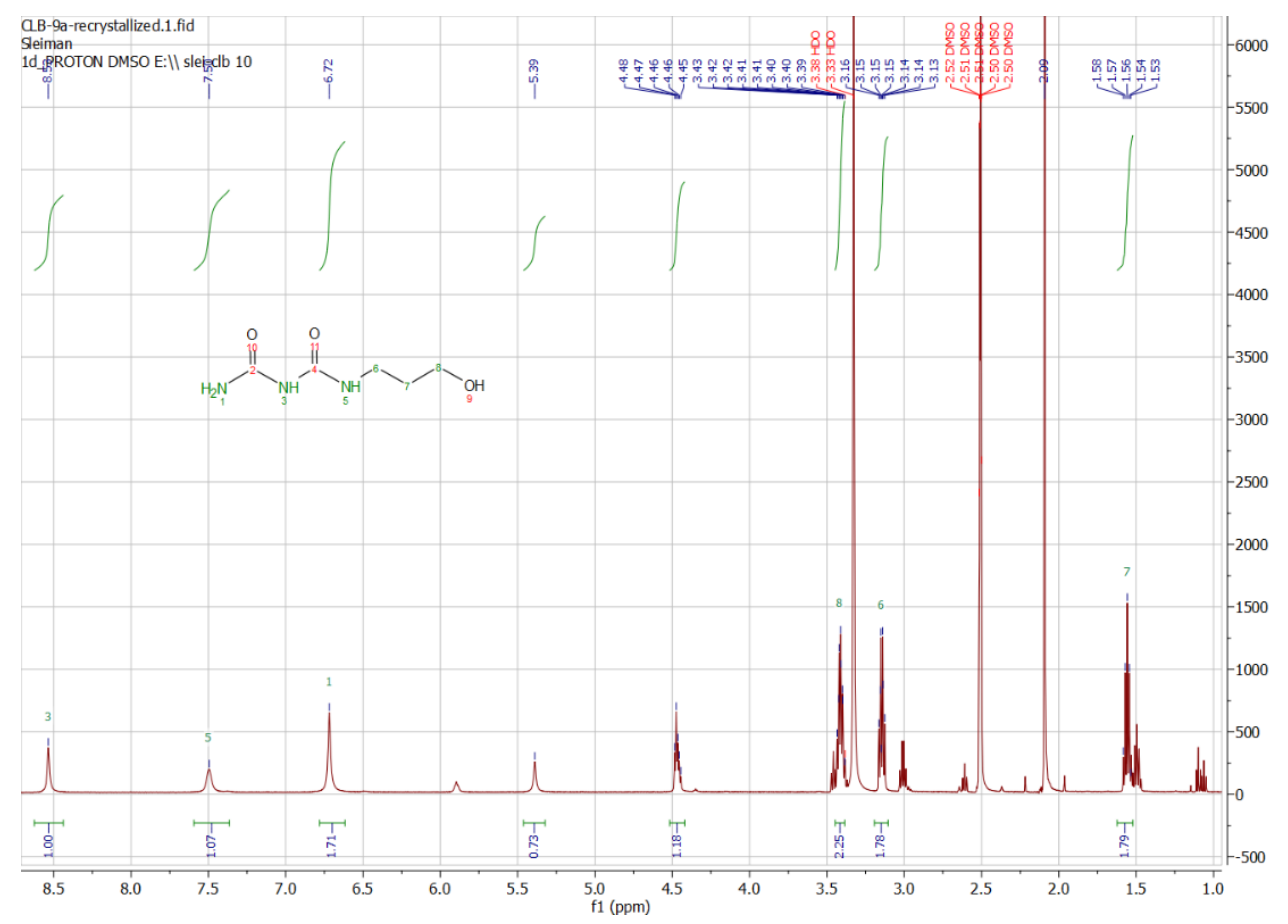

${ }^{1} \mathrm{H}$ NMR $\left(500 \mathrm{MHz}\right.$, DMSO- $\left.d_{6}\right) \delta 8.53(\mathrm{~s}, 1 \mathrm{H}), 7.50(\mathrm{~s}, 1 \mathrm{H}), 6.72(\mathrm{~s}, 2 \mathrm{H}), 5.39(\mathrm{~s}, 1 \mathrm{H}), 4.46(\mathrm{dt}, J=9.3,5.2 \mathrm{~Hz}, 1 \mathrm{H}), 3.41$ ( qd, $J=6.4,5.3 \mathrm{~Hz}, 2 \mathrm{H}), 3.15(\mathrm{td}, J=6.8,5.7 \mathrm{~Hz}, 2 \mathrm{H}), 1.56(\mathrm{q}, J=6.5 \mathrm{~Hz}, 2 \mathrm{H})$. 


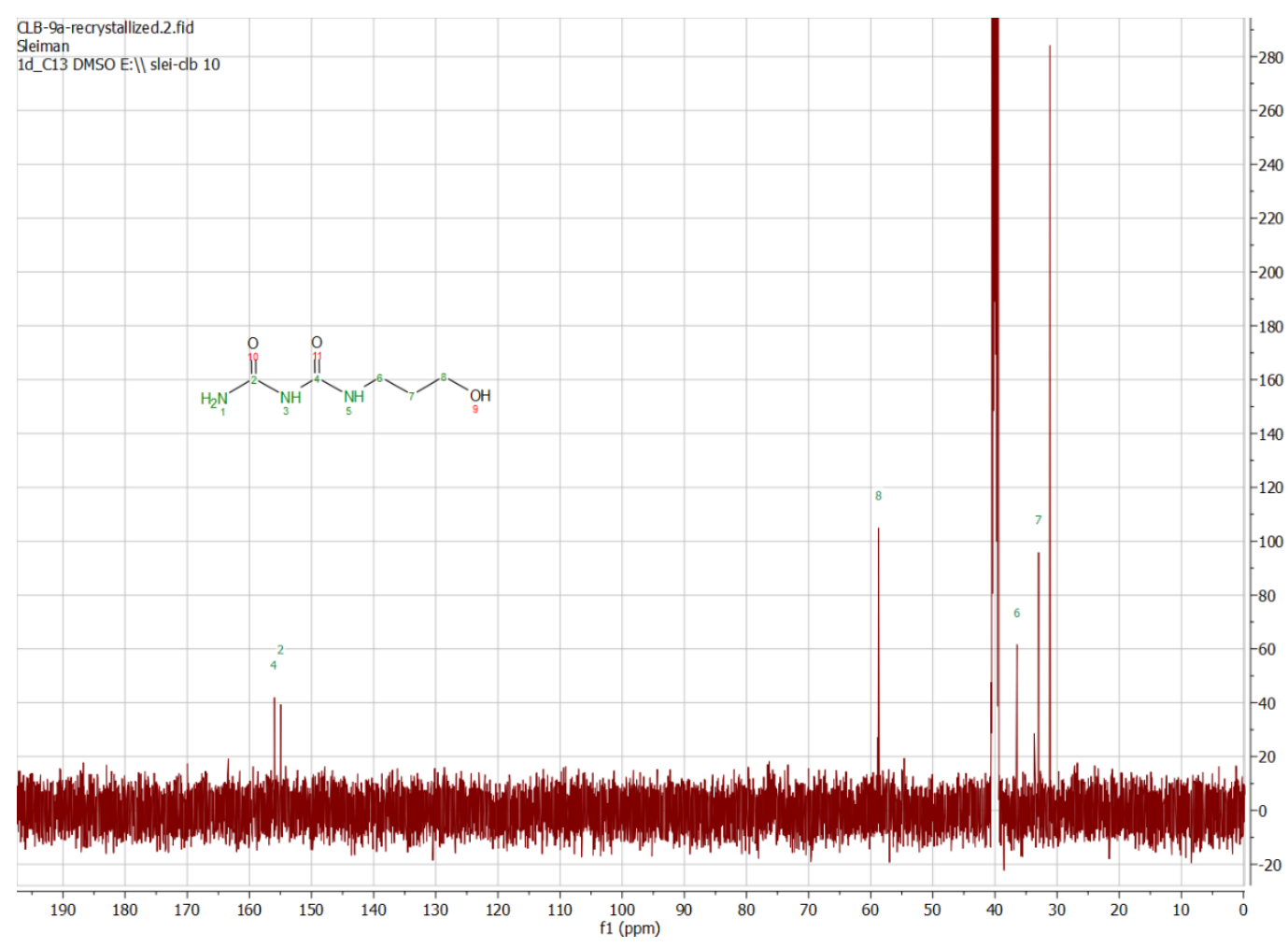

${ }^{13} \mathrm{C}$ NMR $\left(126 \mathrm{MHz}\right.$, DMSO- $\left.d_{6}\right) \delta 155.98,154.94,58.73,36.45,32.99$.

C4OH-biuret : Yield 76\% HRESI-MS C6H13N3NaO3 calc: 198.0849 found: 198.0842

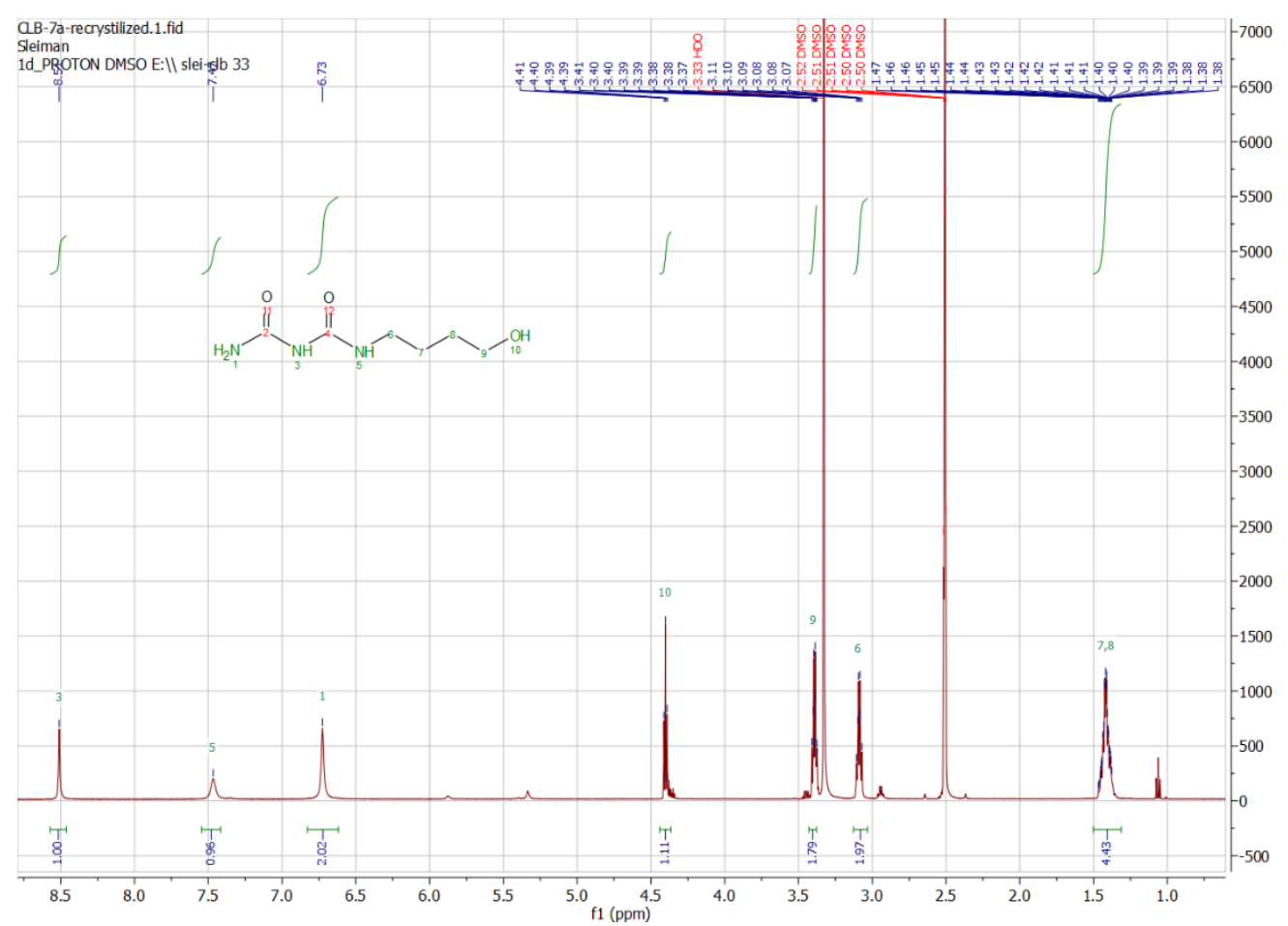


${ }^{1} \mathrm{H}$ NMR $\left(500 \mathrm{MHz}\right.$, DMSO- $\left.d_{6}\right) \delta 8.51(\mathrm{~s}, 1 \mathrm{H}), 7.47(\mathrm{~s}, 1 \mathrm{H}), 6.73(\mathrm{~s}, 2 \mathrm{H}), 4.40(\mathrm{t}, J=5.2 \mathrm{~Hz}, 1 \mathrm{H}), 3.43-3.38(\mathrm{~m}, 2 \mathrm{H}), 3.13$ $-3.03(\mathrm{~m}, 2 \mathrm{H}), 1.41(\mathrm{tqd}, J=9.5,4.4,3.5,1.9 \mathrm{~Hz}, 4 \mathrm{H})$.

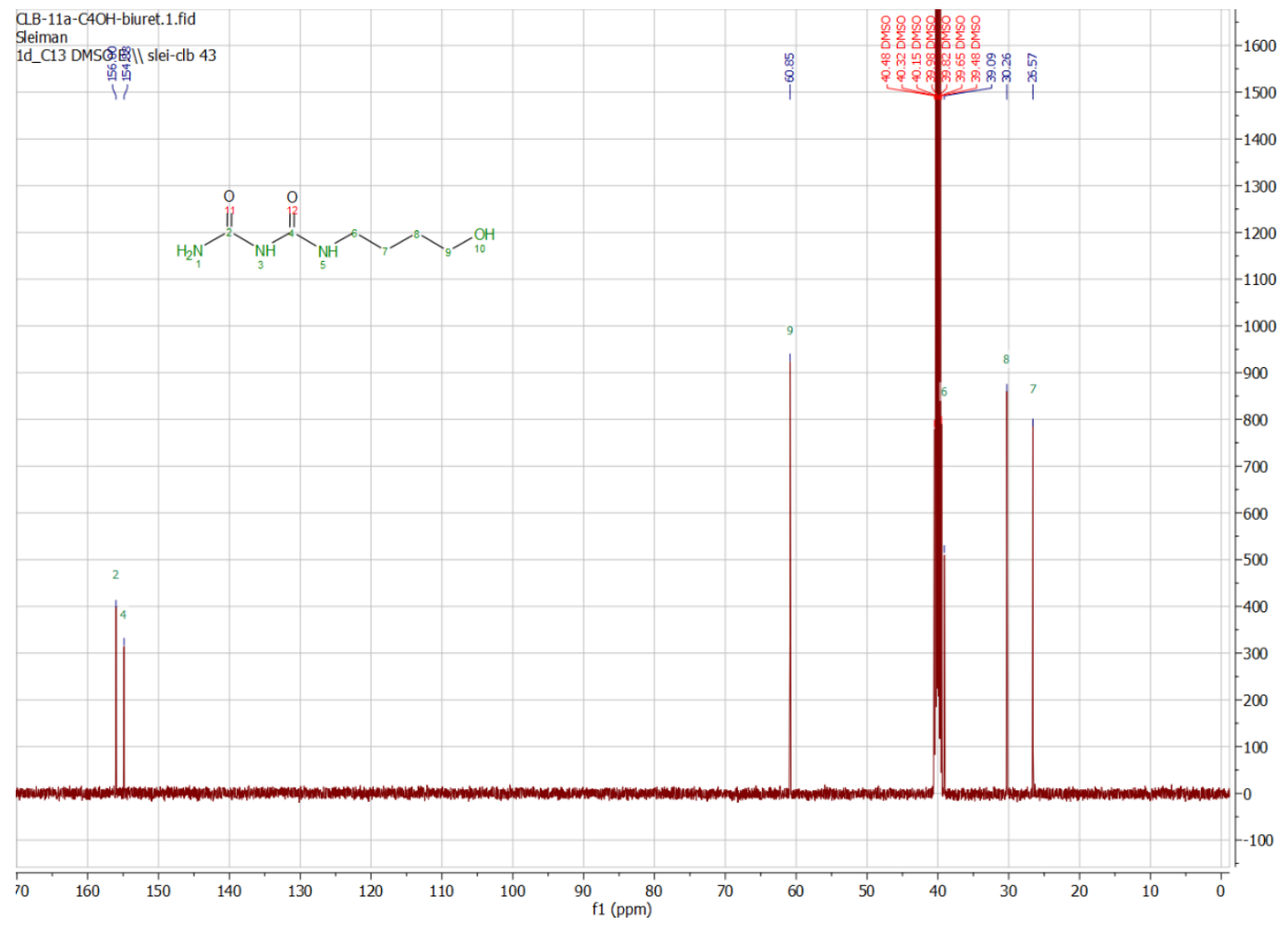

${ }^{13} \mathrm{C}$ NMR (126 MHz, DMSO- $\left.d_{6}\right) \delta 156.00,154.88,60.85,39.09,30.26,26.57$.

C5OH-biuret : Yield 84\% HRESI-MS C7H15N3NaO3 calc: 212.1006 found: 212.0998 


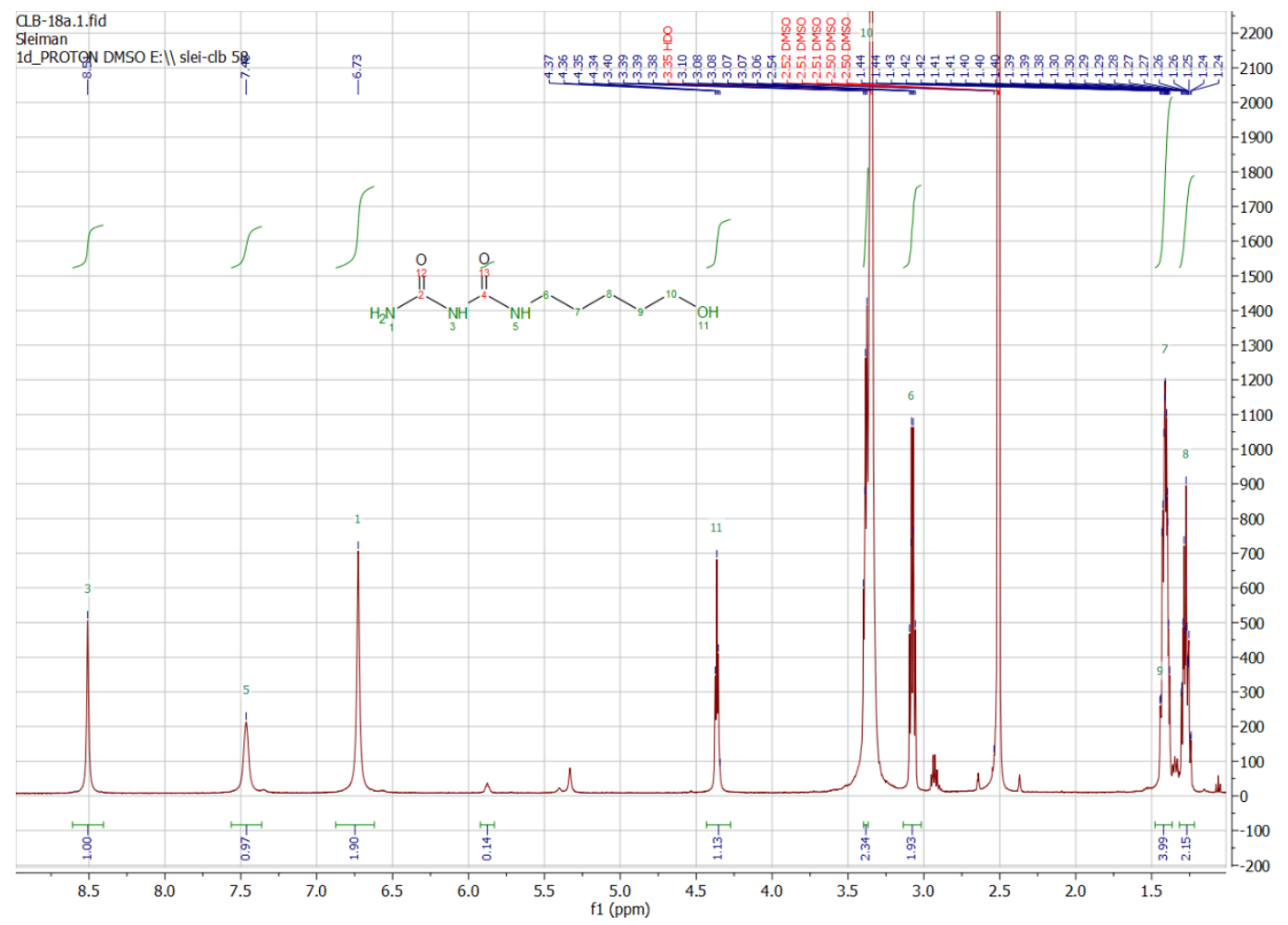

${ }^{1} \mathrm{H}$ NMR $\left(500 \mathrm{MHz}, \mathrm{DMSO}-d_{6}\right) \delta 8.51(\mathrm{~s}, 1 \mathrm{H}), 7.46(\mathrm{~s}, 1 \mathrm{H}), 6.73(\mathrm{~s}, 2 \mathrm{H}), 4.36(\mathrm{t}, J=5.2 \mathrm{~Hz}, 1 \mathrm{H}), 3.40-3.37(\mathrm{~m}, 2 \mathrm{H}), 3.08$ $(\mathrm{td}, J=6.9,5.6 \mathrm{~Hz}, 2 \mathrm{H}), 1.48-1.36(\mathrm{~m}, 4 \mathrm{H}), 1.32-1.22(\mathrm{~m}, 2 \mathrm{H})$.

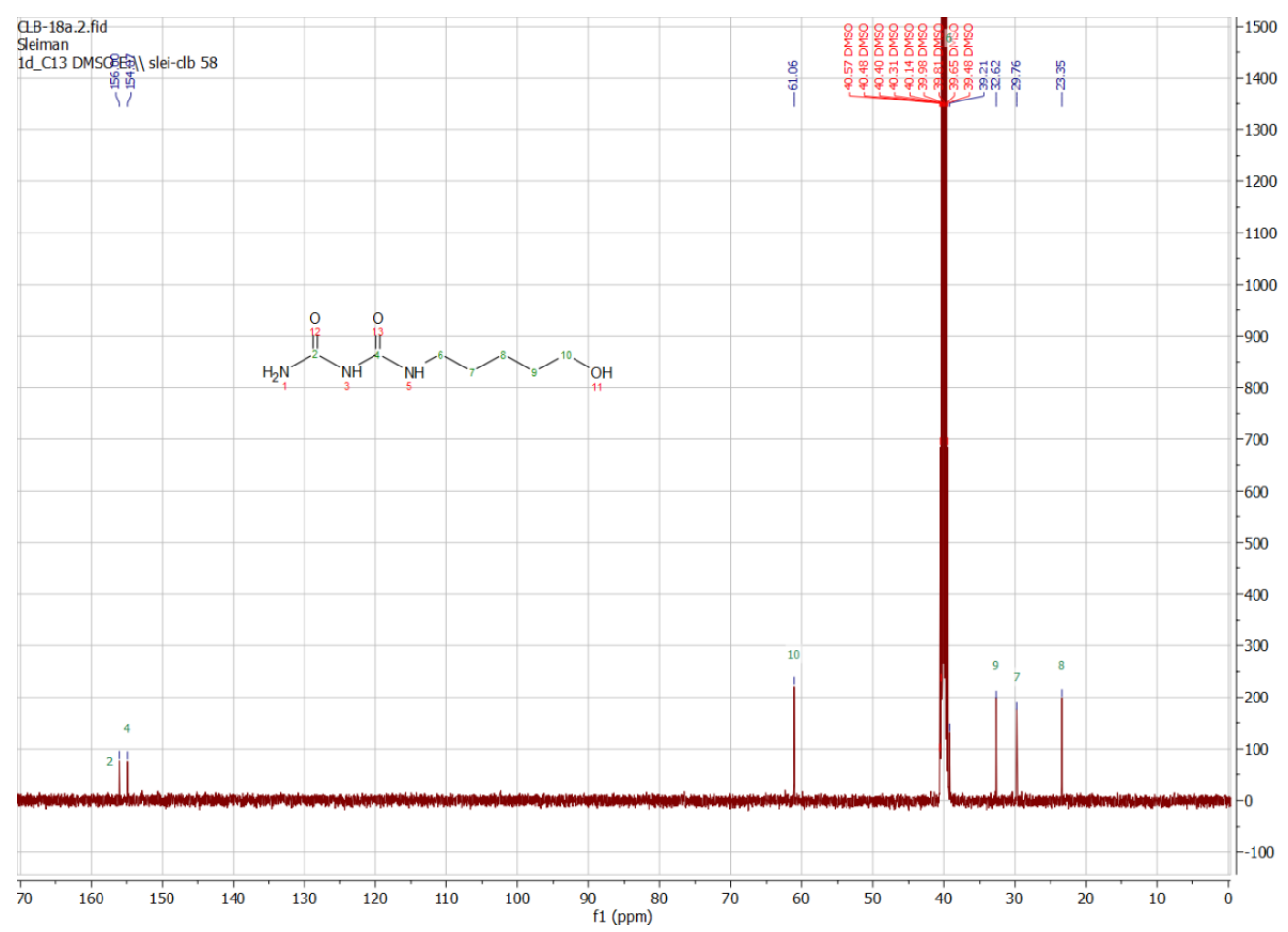

${ }^{13} \mathrm{C}$ NMR (126 MHz, DMSO-d $)$ ) $156.00,154.87,61.06,39.21,32.62,29.76,23.35$.

C6OH-biuret : Yield 81\% HRESI-MS C8H17N3NaO3 calc: 226.1162 found: 226.1155 


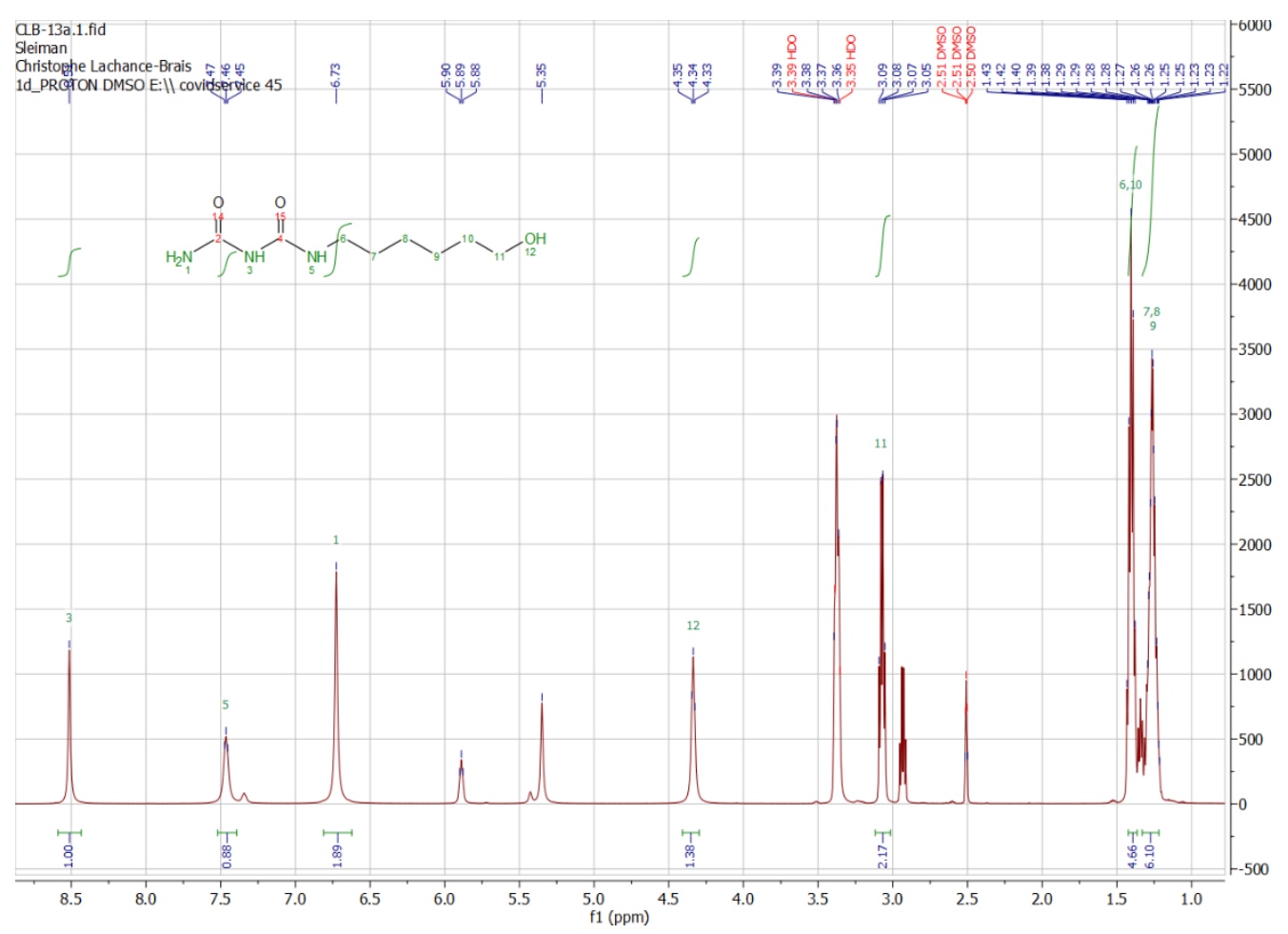

${ }^{1} \mathrm{H} \mathrm{NMR}\left(500 \mathrm{MHz}, \mathrm{DMSO}-d_{6}\right) \delta 8.51(\mathrm{~s}, 1 \mathrm{H}), 7.52-7.39(\mathrm{~m}, 1 \mathrm{H}), 6.73(\mathrm{~s}, 2 \mathrm{H}), 4.34(\mathrm{~d}, J=5.0 \mathrm{~Hz}, 1 \mathrm{H}), 3.07(\mathrm{q}, J=6.6 \mathrm{~Hz}$, $2 \mathrm{H}), 1.40(\mathrm{q}, J=6.8 \mathrm{~Hz}, 5 \mathrm{H}), 1.26(\mathrm{tp}, J=9.8,3.6 \mathrm{~Hz}, 6 \mathrm{H})$.

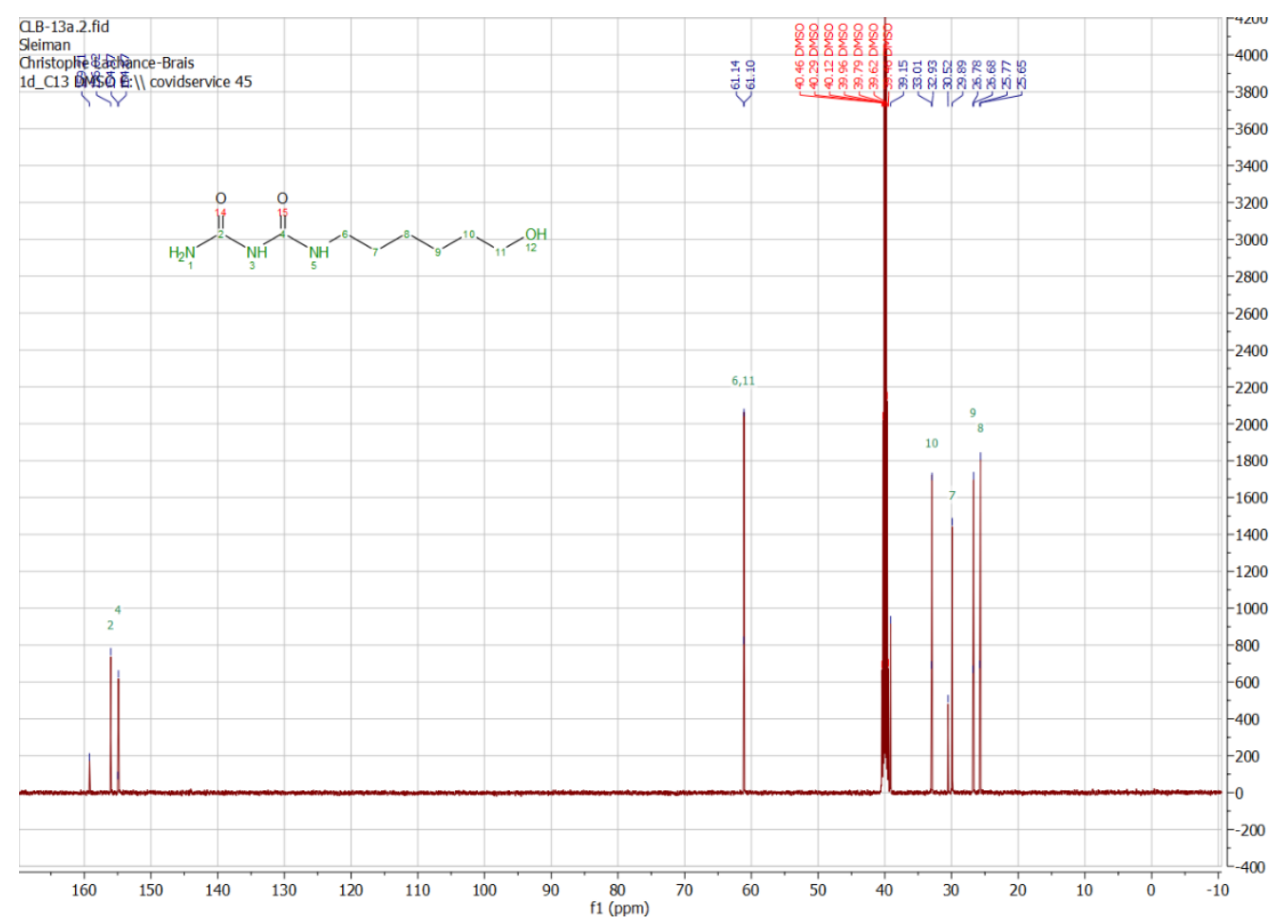

${ }^{13} \mathrm{C}$ NMR (126 MHz, DMSO-d $\left.d_{6}\right) \delta 156.02,154.87,61.14,61.10,32.93,29.89,26.68,25.65$. 
c) General procedure for the synthesis of $\mathrm{CA}-\mathrm{Cn}-\mathrm{OH}(\mathrm{n}=2$ to 6$)$

The according monosubstituted $\mathrm{CnOH}$-biuret $(1$ eq. , $0.5 \mathrm{M}$ ) was dissolved in a $1 \mathrm{M} \mathrm{NaOEt}$ solution in EtOH. Diethylcarbonate ( 2 eq.) was added and the solution was heated to reflux for $2 \mathrm{~h}$. After cooling to room temperature, it was filtered and the precipitate recuperated. The precipitate was then dissolved in the minimal amount of water, and to it was added concentrated $\mathrm{HCl}$. The precipitate formed was filtered and washed with twice with $5 \mathrm{~mL}$ of cold water, once with $5 \mathrm{~mL}$ of cold EtOH and twice with $5 \mathrm{~mL}$ of $\mathrm{Et}_{2} \mathrm{O}$. The resulting powder was kept in the desiccator prior to experiments and characterized with HRMS, ${ }^{1} \mathrm{H}$ and ${ }^{13} \mathrm{C} \mathrm{NMR}$. 
CA-C2-OH : Yield $22.7 \%$ (118.42 mg, $0.68 \mathrm{mmol}$ ) HRESI-MS C5H7N3NaO4 calc: 196.0329 found: 196.0329

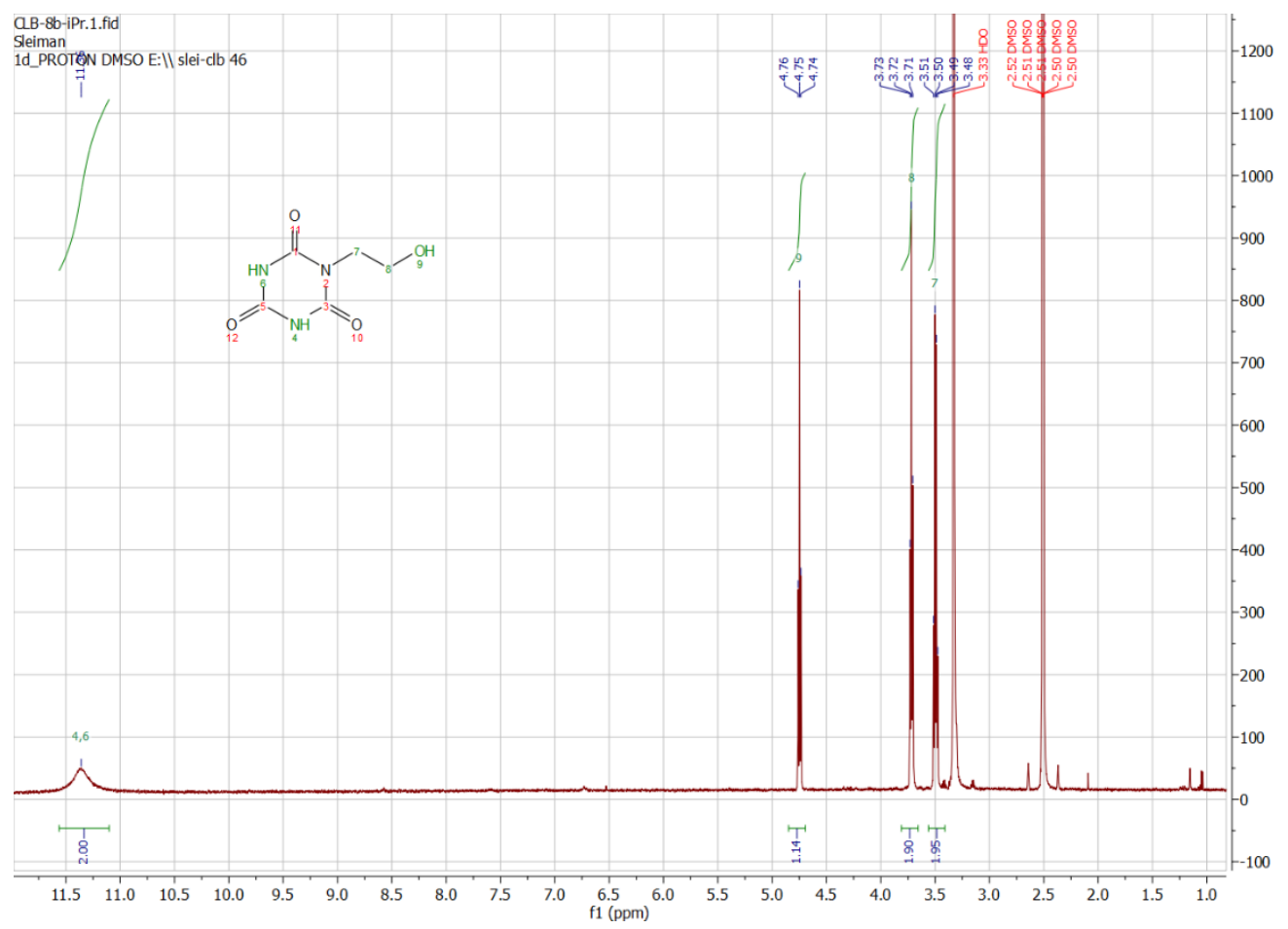

${ }^{1} \mathrm{H}$ NMR (500 MHz, DMSO-d 6 ) $\delta 11.36(\mathrm{~s}, 2 \mathrm{H}), 4.75(\mathrm{t}, J=6.2 \mathrm{~Hz}, 1 \mathrm{H}), 3.72(\mathrm{t}, J=6.3 \mathrm{~Hz}, 2 \mathrm{H}), 3.49(\mathrm{q}, J=6.2 \mathrm{~Hz}, 2 \mathrm{H})$.

a.B-8b-iPr.2.fid

1d_C13 DMSO E: || slei-db 46
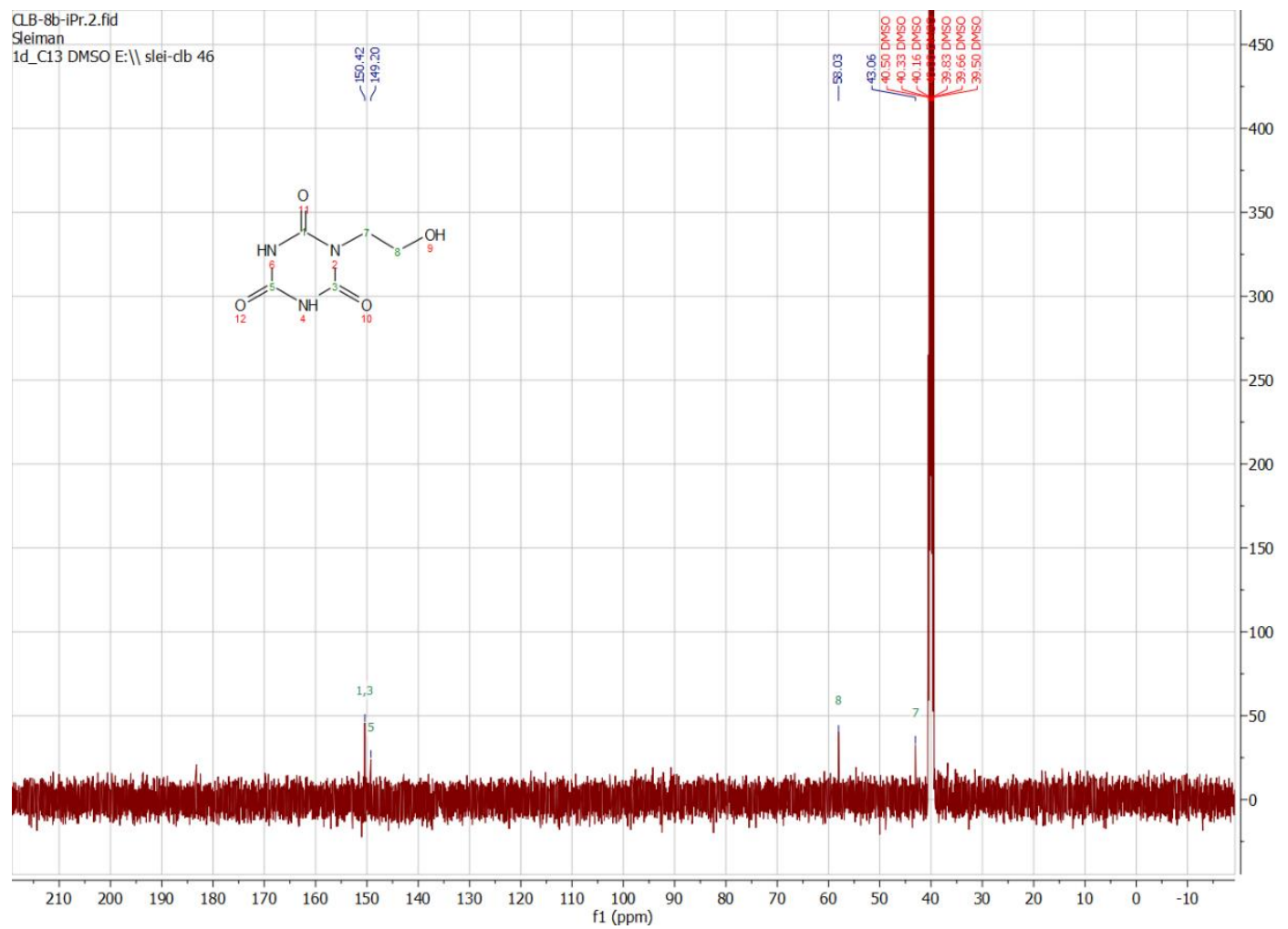
${ }^{13} \mathrm{C}$ NMR $(126 \mathrm{MHz}$, DMSO-d $) \delta 150.42,58.03,43.06$.

CA-C3-OH : Yield $27.2 \%$ (152.62 mg, $0.82 \mathrm{mmol}$ ) HRESI-MS C6H9N3NaO4 calc: 210.0485 found: 210.0480

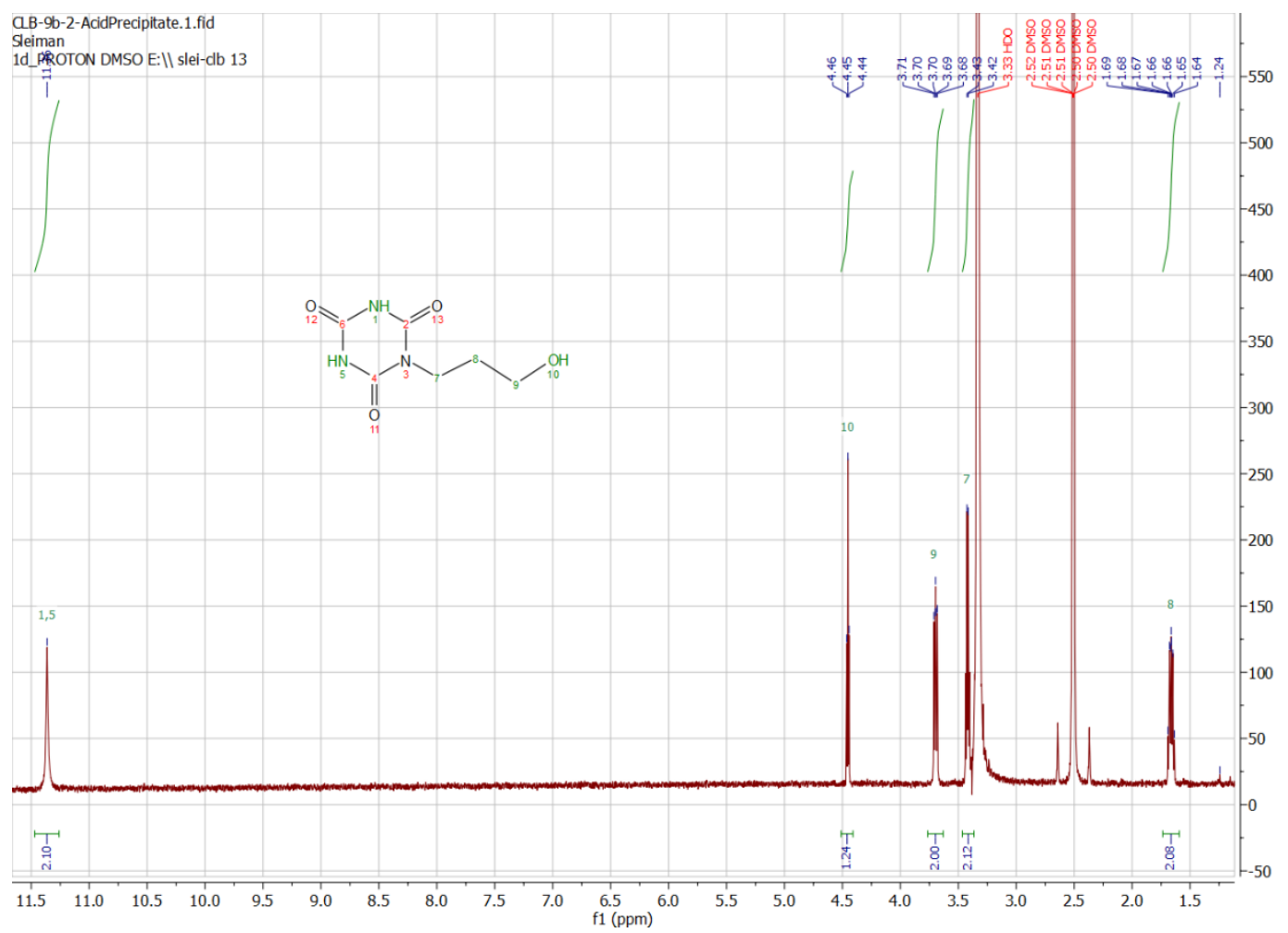

${ }^{1} \mathrm{H}$ NMR $\left(500 \mathrm{MHz}, \mathrm{DMSO}-d_{6}\right) \delta 11.36(\mathrm{~s}, 2 \mathrm{H}), 4.45(\mathrm{t}, J=5.1 \mathrm{~Hz}, 1 \mathrm{H}), 3.76-3.63(\mathrm{~m}, 2 \mathrm{H}), 3.42(\mathrm{~d}, J=5.1 \mathrm{~Hz}, 2 \mathrm{H}), 1.74$ $-1.59(\mathrm{~m}, 2 \mathrm{H})$.

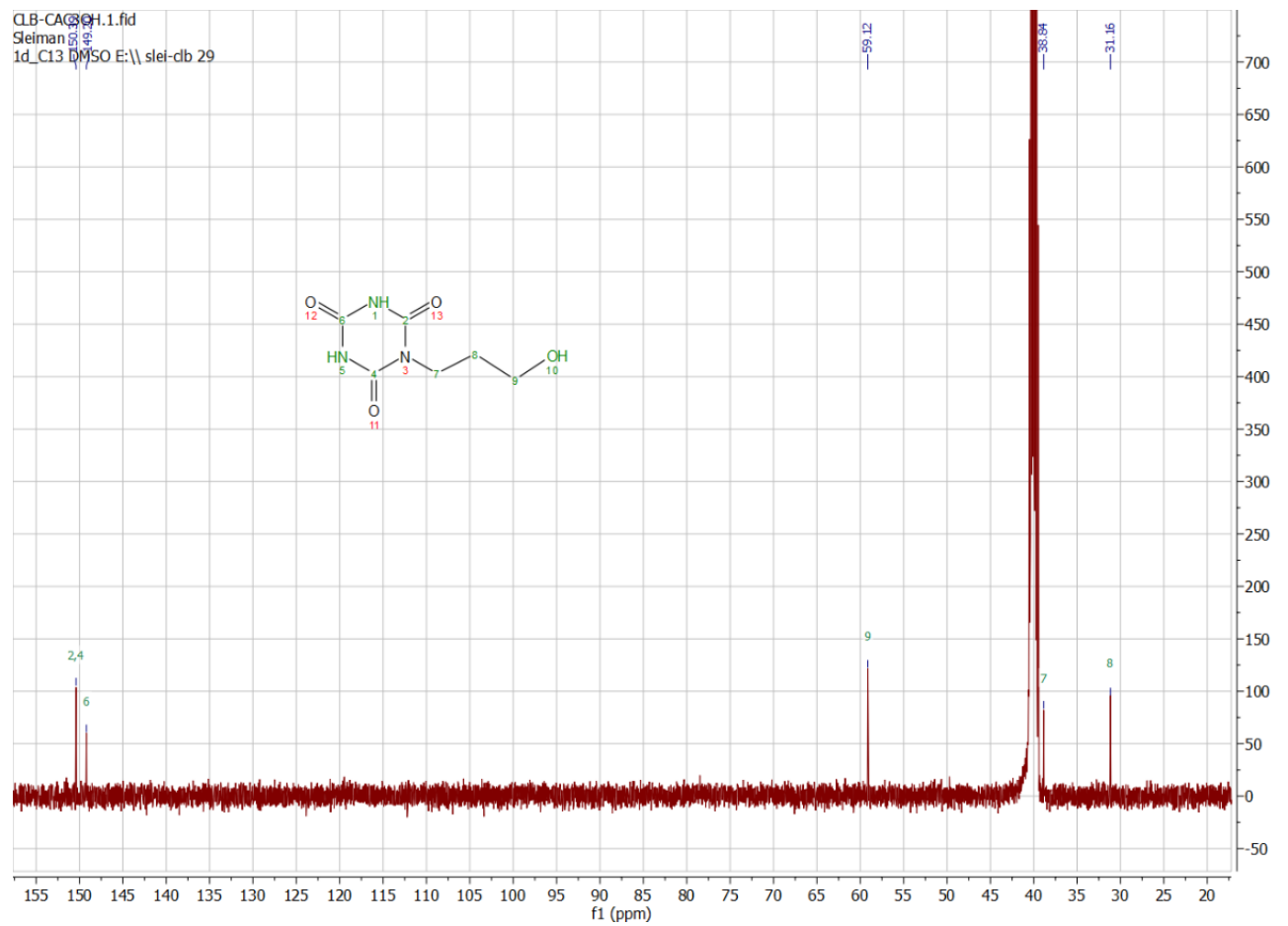


${ }^{13} \mathrm{C}$ NMR $(126 \mathrm{MHz}$, DMSO-d $) \delta 149.20,59.12,38.84,31.16$.

CA-C4-OH : Yield 46.9\% ( 443.20 mg , 2.2 mmol) HRESI-MS C7H1 1N3NaO4 calc: 224.0642 found: 224.0643

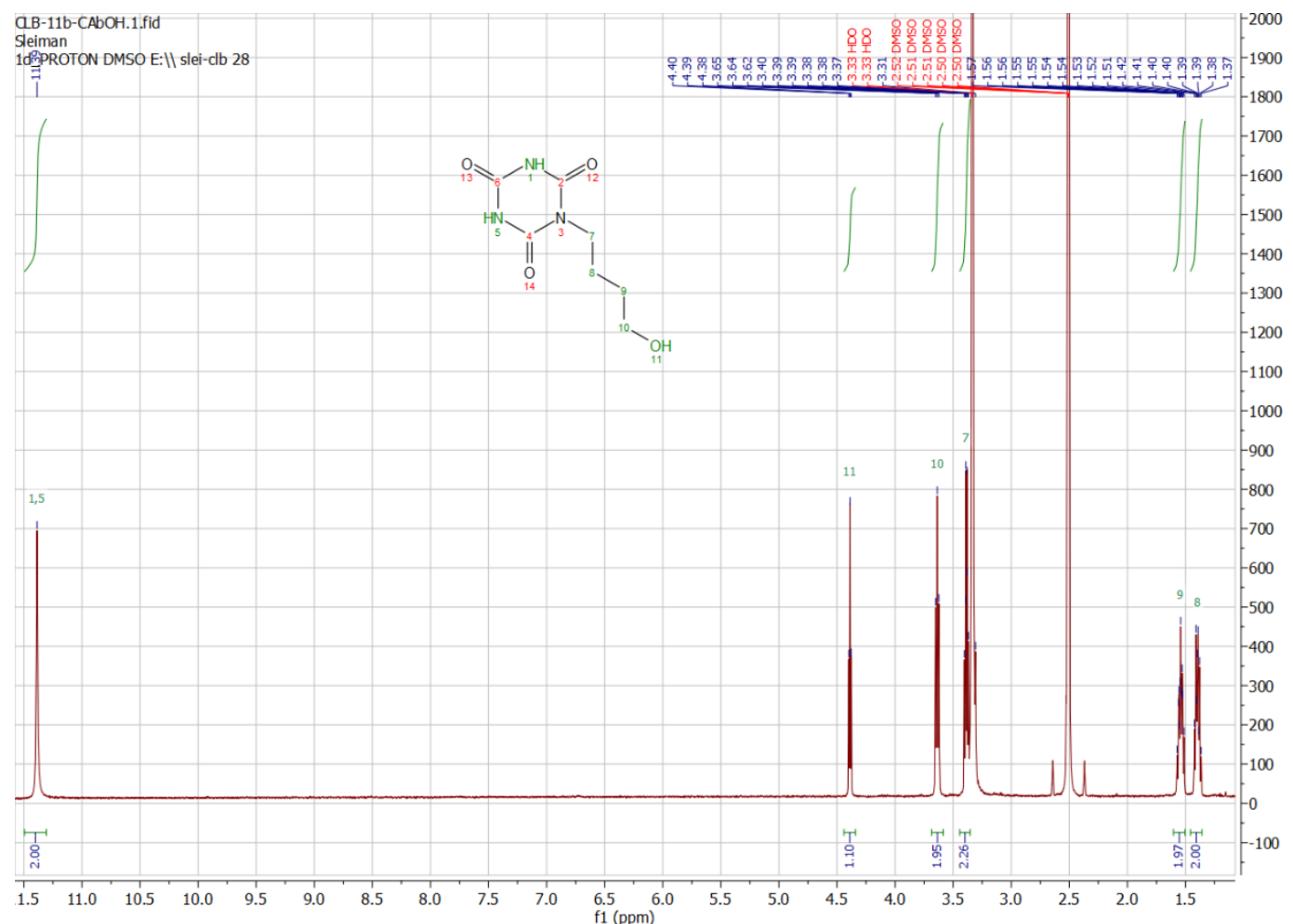

${ }^{1} \mathrm{H} \mathrm{NMR}\left(500 \mathrm{MHz}, \mathrm{DMSO}-d_{6}\right) \delta 11.39(\mathrm{~s}, 2 \mathrm{H}), 4.39(\mathrm{t}, J=5.1 \mathrm{~Hz}, 1 \mathrm{H}), 3.64(\mathrm{t}, J=7.3 \mathrm{~Hz}, 2 \mathrm{H}), 3.39(\mathrm{td}, J=6.4,5.1 \mathrm{~Hz}, 2 \mathrm{H})$, $1.54(\mathrm{ddt}, J=12.1,8.6,3.9 \mathrm{~Hz}, 2 \mathrm{H}), 1.39(\mathrm{dq}, J=10.1,6.5 \mathrm{~Hz}, 2 \mathrm{H})$.

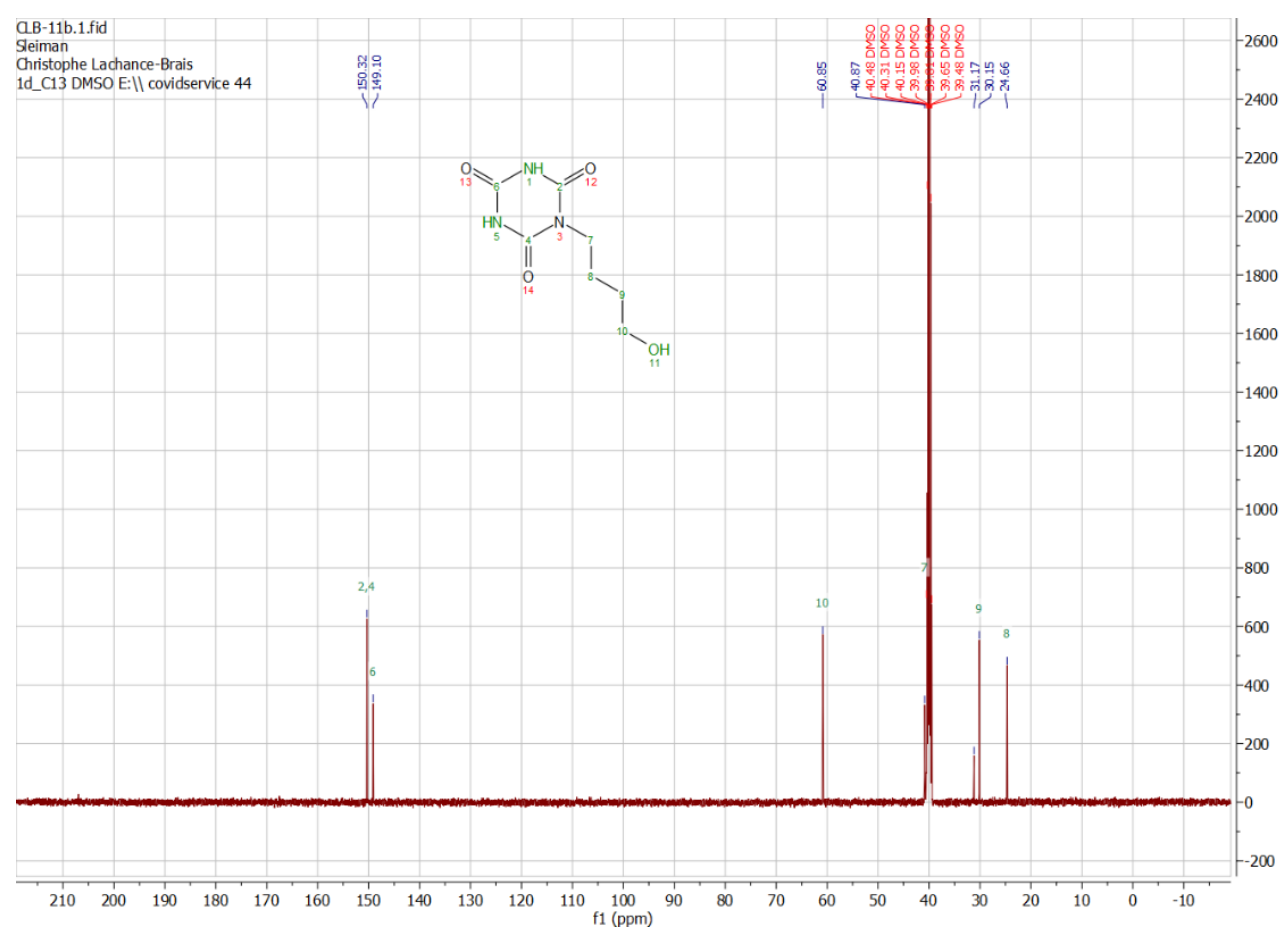


${ }^{13} \mathrm{C}$ NMR $\left(126 \mathrm{MHz}, \mathrm{DMSO}-d_{6}\right) \delta 150.32,149.10,60.85,40.87,30.15,24.66$.

CA-C5-OH : Yield 51.8\% (235.77 mg, $1.1 \mathrm{mmol}$ ) HRESI-MS C8H13N3NaO4 calc: 238.0798 found: 238.0801

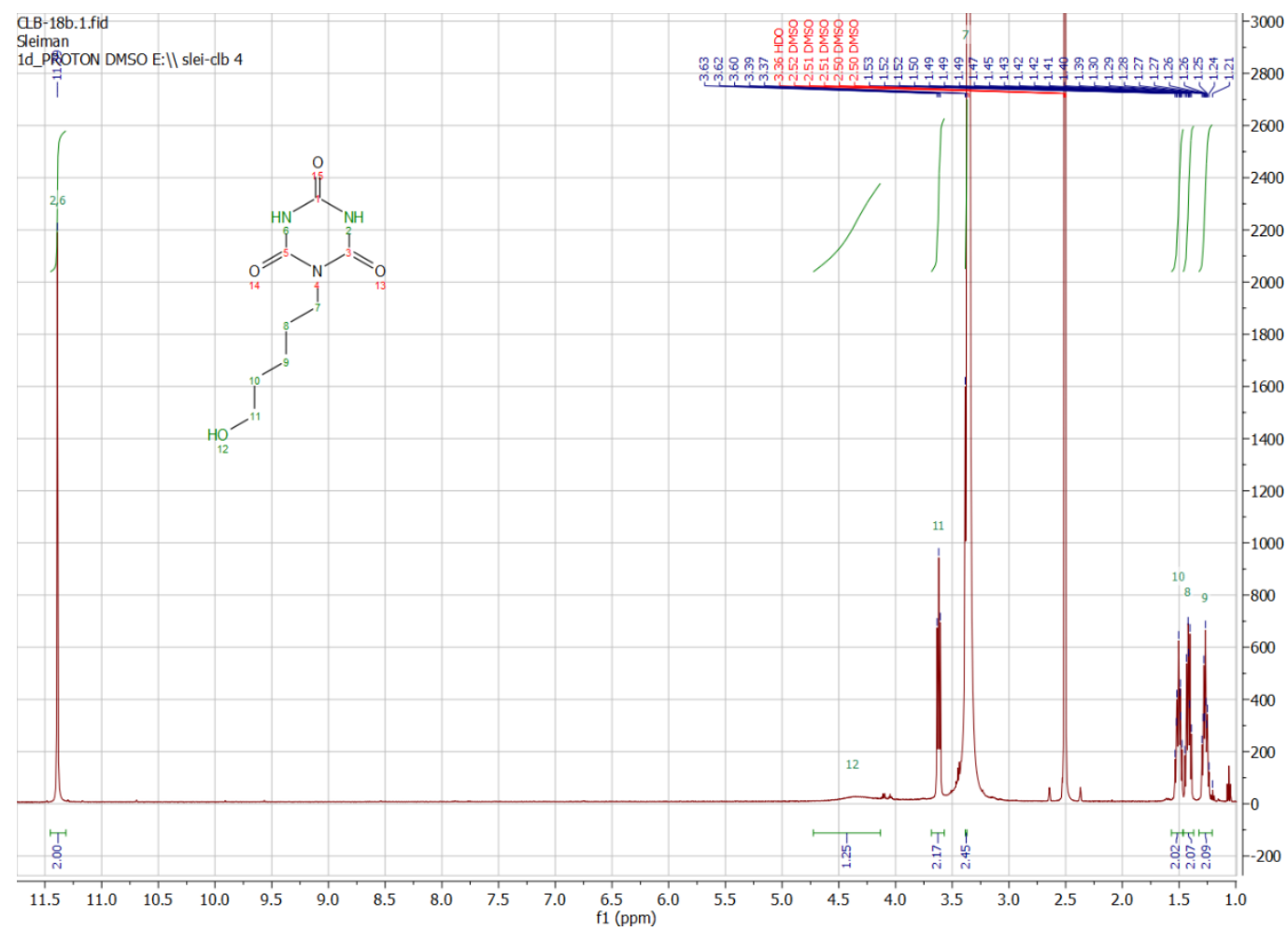

${ }^{1} \mathrm{H}$ NMR $\left(500 \mathrm{MHz}, \mathrm{DMSO}-d_{6}\right) \delta 11.39(\mathrm{~s}, 2 \mathrm{H}), 4.43(\mathrm{~d}, J=58.0 \mathrm{~Hz}, 1 \mathrm{H}), 3.68-3.57(\mathrm{~m}, 2 \mathrm{H}), 3.37(\mathrm{~s}, 2 \mathrm{H}), 1.57-1.46(\mathrm{~m}$, $2 \mathrm{H}), 1.46-1.37(\mathrm{~m}, 2 \mathrm{H}), 1.27(\mathrm{tt}, J=9.6,5.9 \mathrm{~Hz}, 2 \mathrm{H})$.

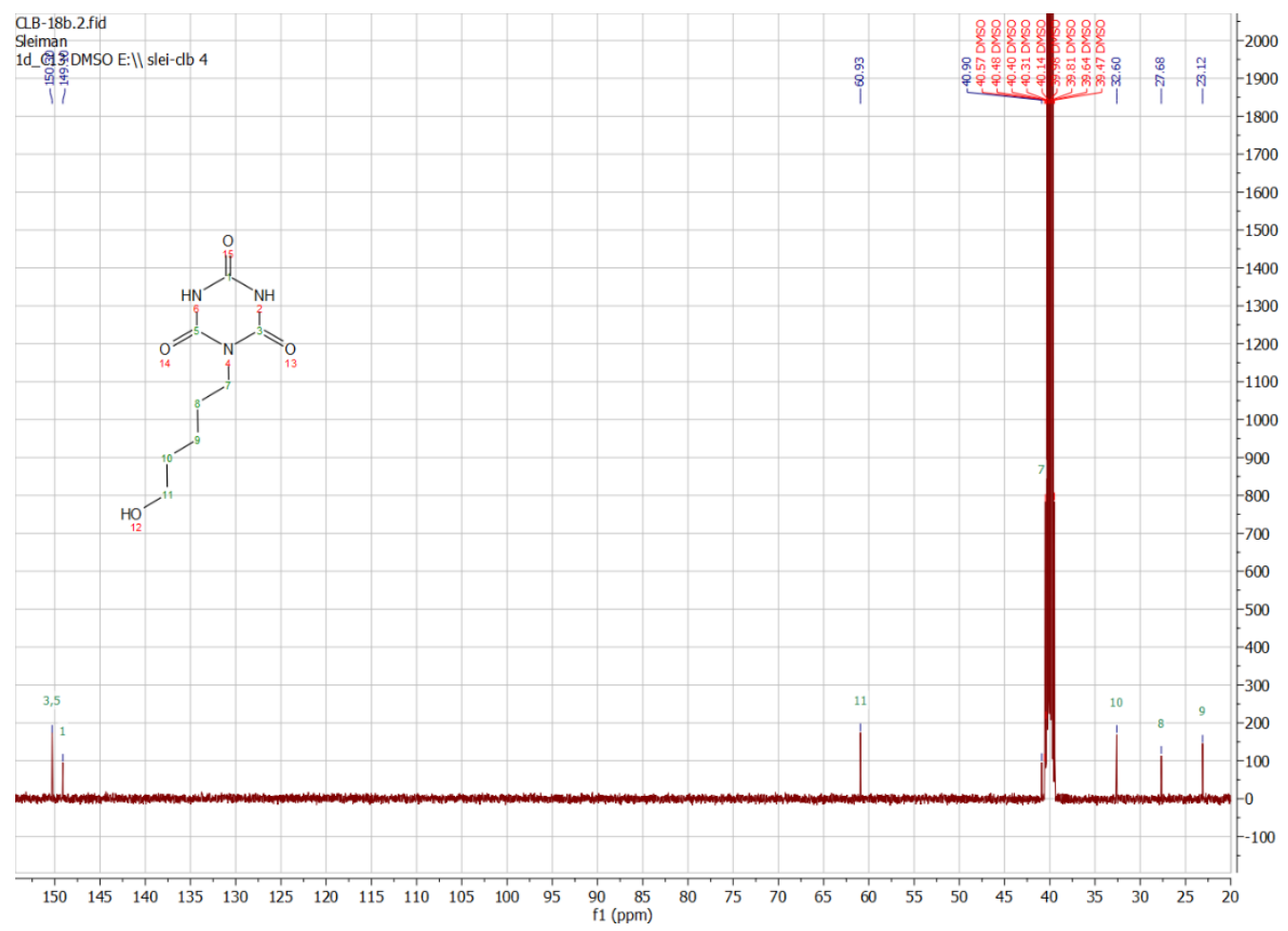


${ }^{13} \mathrm{C}$ NMR $\left(126 \mathrm{MHz}\right.$, DMSO- $\left.d_{6}\right) \delta 150.30,149.10,60.93,40.90,32.60,27.68,23.12$.

CA-C6-OH : Yield 63.9\% (302.64 mg, 1.3 mmol) HRESI-MS C9H15N3NaO4 calc: 252.0955 found: 252.0949

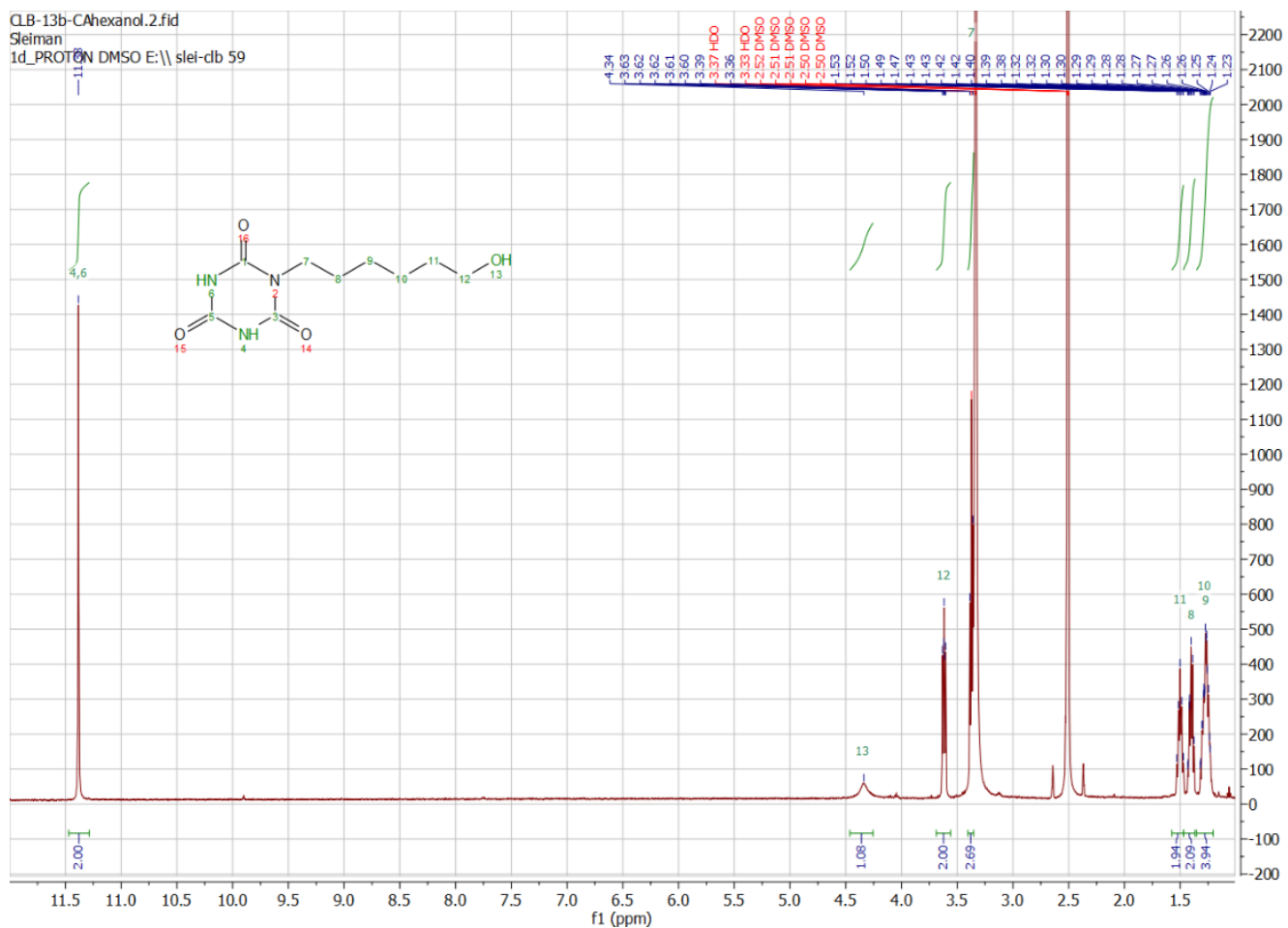

${ }^{1} \mathrm{H}$ NMR (500 MHz, DMSO- $\left.d_{6}\right) \delta 11.38(\mathrm{~s}, 2 \mathrm{H}), 4.34(\mathrm{~s}, 1 \mathrm{H}), 3.69-3.56(\mathrm{~m}, 2 \mathrm{H}), 3.37(\mathrm{~d}, J=13.1 \mathrm{~Hz}, 3 \mathrm{H}), 1.50(\mathrm{p}, J=7.4$ $\mathrm{Hz}, 2 \mathrm{H}), 1.41(\mathrm{dq}, J=13.7,6.6,6.1 \mathrm{~Hz}, 2 \mathrm{H}), 1.35-1.20(\mathrm{~m}, 4 \mathrm{H})$.

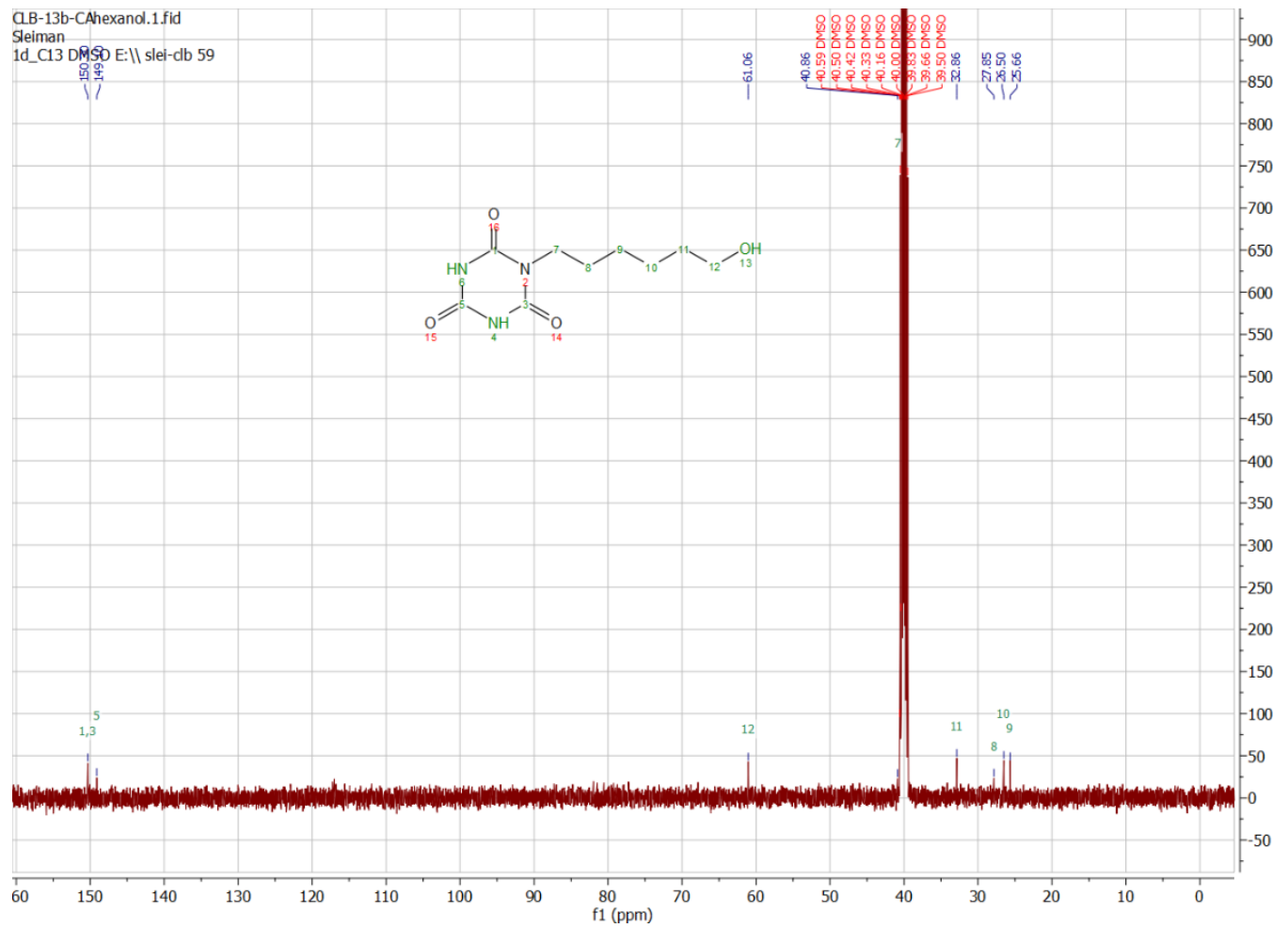


${ }^{13} \mathrm{C}$ NMR $(126 \mathrm{MHz}$, DMSO-d $) \delta 150.30,149.10,61.06,40.87,32.86,26.50,25.66$.

\section{ii. Synthesis of amino substituted cyanurates}

The synthesis was performed in three steps following the pathway presented in Scheme 2.30-31

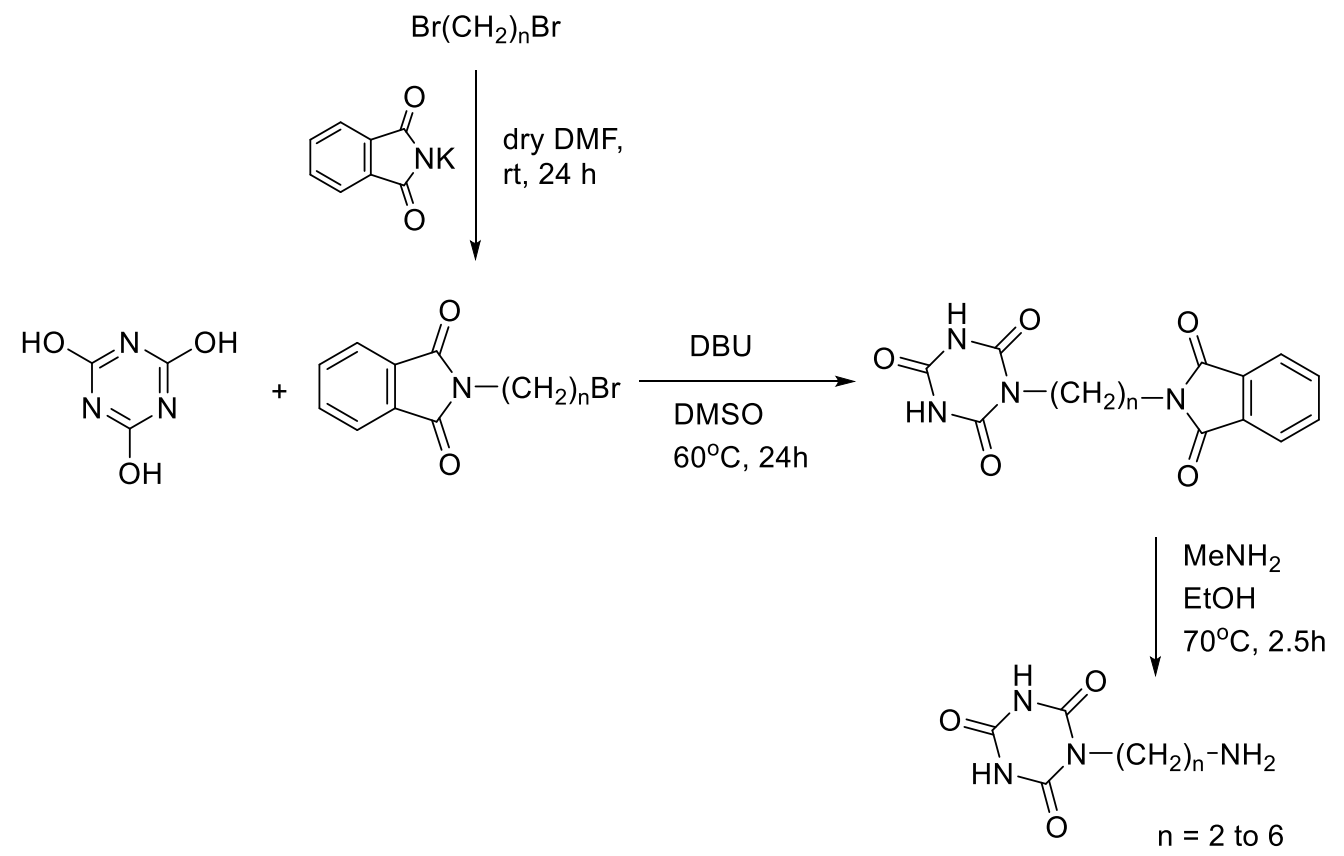

Scheme 2: General procedure for the synthesis of amino substituted cyanurates.

a) General procedure for the synthesis of $\mathrm{N}$-( $\mathrm{n}$-bromoalkyl)phthalimide ( $\mathrm{n}=2$ to 6 ) Potassium phthalimide ( $13.5 \mathrm{mmol}, 1$ eq.) and 1,n-dibromoalkane (3 eq.) were stirred in $5 \mathrm{~mL}$ dry DMF overnight. The solvent was evaporated under reduced pressure. The residue (exception of $n=2$ ) was triturated with hexanes. The solids were separated by filtration. Purification by column chromatography gave $\mathrm{N}$-(n-bromoalkyl)phthalimide as white solids. For $\mathrm{n}=2$, after the solvent was removed under reduced pressure, the residue was dissolved in ethyl acetate and extracted twice with water. The organic layer was washed successively with saturated aqueous $\mathrm{NH}_{4} \mathrm{Cl}$ and $\mathrm{NaCl}$, dried over $\mathrm{Mg}_{2} \mathrm{SO}_{4}$, filtered, and concentrated to give $\mathrm{N}$-(2-bromoethyl)phthalimide as a white crystalline solid. The structure and purity of the products were assessed by ${ }^{1} \mathrm{H}$ and ${ }^{13} \mathrm{C}$ NMR.

N-(2-bromoethyl)phthalimide $(\mathrm{n}=2)$. Yield: $72.1 \%$

${ }^{1} \mathrm{H}$ NMR $\left(500 \mathrm{MHz}, \mathrm{CDCl}_{3}\right) \delta: 7.88(\mathrm{dd}, \mathrm{J}=5.5,3.0 \mathrm{~Hz}, 2 \mathrm{H}, \mathrm{ArH}), 7.75(\mathrm{dd}, \mathrm{J}=5.5,3.0 \mathrm{~Hz}, 2 \mathrm{H}, \mathrm{ArH}), 4.12(\mathrm{t}, \mathrm{J}=6.7 \mathrm{~Hz}$, $\left.2 \mathrm{H}, \mathrm{PhNCH}_{2}\right), 3.63\left(\mathrm{t}, \mathrm{J}=6.7 \mathrm{~Hz}, 2 \mathrm{H}, \mathrm{CH}_{2} \mathrm{Br}\right)$. 
${ }^{13} \mathrm{C} \mathrm{NMR}\left(126 \mathrm{MHz}, \mathrm{CDCl}_{3}\right) \delta: 167.83,134.24,131.83,123.53,39.30,28.19$.

N-(3-bromoproyl)phthalimide $(n=3)$. Yield: $72 \%\left(R_{f}=0.62\right.$, Hexanes : Ethyl Acetate, $\left.3: 2(v: v)\right)$

${ }^{1} \mathrm{H} \mathrm{NMR}\left(400 \mathrm{MHz}, \mathrm{CDCl}_{3}\right) \delta: 7.87(\mathrm{dd}, J=5.2,3.0 \mathrm{~Hz}, 2 \mathrm{H}, \mathrm{ArH}), 7.76(\mathrm{dd}, J=5.6,3.0 \mathrm{~Hz}, 2 \mathrm{H}, \mathrm{ArH}), 3.84(\mathrm{t}, J=6.8 \mathrm{~Hz}$, $\left.2 \mathrm{H}, \mathrm{PhNCH}_{2}\right), 3.41\left(\mathrm{t}, J=6.4 \mathrm{~Hz}, 2 \mathrm{H}, \mathrm{CH}_{2} \mathrm{Br}\right), 2.26\left(\mathrm{p}, J=6.8 \mathrm{~Hz}, 2 \mathrm{H},\left(\mathrm{CH}_{2}\right) \mathrm{CH}_{2} \mathrm{Br}\right)$.

${ }^{13} \mathrm{C} \mathrm{NMR}\left(126 \mathrm{MHz}, \mathrm{CDCl}_{3}\right) \delta: 168.24,134.06,132.01,123.33,36.24,31.65,29.78$.

N-(4-bromobutyl)phthalimide $(\mathrm{n}=4)$. Yield: $39.5 \%\left(\mathrm{R}_{\mathrm{f}}=0.66\right.$, Hexanes : Ethyl Acetate, $\left.3: 2(\mathrm{v}: \mathrm{v})\right)$

${ }^{1} \mathrm{H} \mathrm{NMR}\left(500 \mathrm{MHz}, \mathrm{CDCl}_{3}\right) \delta: 7.84(\mathrm{dd}, J=5.4,3.0 \mathrm{~Hz}, 2 \mathrm{H}, \mathrm{ArH}), 7.72(\mathrm{dd}, J=5.5,3.0 \mathrm{~Hz}, 2 \mathrm{H}, \mathrm{ArH}), 3.72(\mathrm{t}, J=6.7 \mathrm{~Hz}$, $\left.2 \mathrm{H}, \mathrm{PhNCH}_{2}\right), 3.44\left(\mathrm{t}, J=6.4 \mathrm{~Hz}, 2 \mathrm{H}, \mathrm{CH}_{2} \mathrm{Br}\right), 1.95-1.80\left(\mathrm{~m}, 4 \mathrm{H},\left(\mathrm{CH}_{2}\right)_{2} \mathrm{CH}_{2} \mathrm{Br}\right)$.

${ }^{13} \mathrm{C} \mathrm{NMR}\left(126 \mathrm{MHz}, \mathrm{CDCl}_{3}\right) \delta: 168.37,134.00,132.05,123.27,36.96,32.81,29.85,27.25$.

N-(5-bromopentyl)phthalimide $(n=5)$ Yield: $62.7 \%\left(R_{f}=0.73\right.$, Hexanes : Ethyl Acetate, $\left.3: 2(v: v)\right)$

${ }^{1} \mathrm{H}$ NMR $\left(500 \mathrm{MHz}, \mathrm{CDCl}_{3}\right) \delta: 7.84(\mathrm{dd}, J=5.5,3.0 \mathrm{~Hz}, 2 \mathrm{H}, \mathrm{ArH}), 7.71(\mathrm{dd}, J=5.4,3.1 \mathrm{~Hz}, 2 \mathrm{H}, \mathrm{ArH}), 3.70(\mathrm{t}, J=7.2 \mathrm{~Hz}$, $2 \mathrm{H}, \mathrm{PhNCH}_{2}$ ), 3.40 (t, J=6.8 Hz, 2H, CH $\mathrm{CH}_{2} \mathrm{Br}, 1.93\left(\mathrm{p}, J=7.4 \mathrm{~Hz}, 2 \mathrm{H}, \mathrm{CH}_{2} \mathrm{CH}_{2} \mathrm{Br}\right.$ ), $1.73\left(\mathrm{p}, J=7.4 \mathrm{~Hz}, 2 \mathrm{H}, \mathrm{CH}_{2} \mathrm{CH}_{2} \mathrm{NPh}\right.$ ), $1.52\left(\mathrm{p}, J=7.5 \mathrm{~Hz}, 2 \mathrm{H},\left(\mathrm{CH}_{2}\right)_{2} \mathrm{CH}_{2}\left(\mathrm{CH}_{2}\right)_{2}\right)$.

${ }^{13} \mathrm{C}$ NMR $\left(126 \mathrm{MHz}, \mathrm{CDCl}_{3}\right) \delta: 168.43,133.94,132.12,123.24,37.67,33.39,32.20,27.75,25.40$.

N-(6-bromohexyl)phthalimide $(\mathrm{n}=6)$. Yield: $59.7 \%\left(\mathrm{R}_{\mathrm{f}}=0.68\right.$, Hexanes : Ethyl Acetate, $\left.3: 2(\mathrm{v}: \mathrm{v})\right)$

${ }^{1} \mathrm{H} \operatorname{NMR}\left(500 \mathrm{MHz}, \mathrm{CDCl}_{3}\right) \delta: 7.83(\mathrm{dd}, J=5.4,3.1 \mathrm{~Hz}, 2 \mathrm{H}, \mathrm{ArH}), 7.71(\mathrm{dd}, J=5.4,3.0 \mathrm{~Hz}, 2 \mathrm{H}, \mathrm{ArH}), 3.68(\mathrm{t}, J=7.3 \mathrm{~Hz}$, $2 \mathrm{H}, \mathrm{PhNCH}_{2}$ ), 3.39 (t, J=6.8 Hz, 2H, CH $\mathrm{CH}_{2} \mathrm{Br}, 1.84$ (p, J=7.8 Hz, 2H, $\mathrm{CH}_{2} \mathrm{CH}_{2} \mathrm{Br}$ ), 1.69 (p, J= 7.8 Hz, 2H, $\mathrm{CH}_{2} \mathrm{CH}_{2} \mathrm{NPh}$ ), $1.47\left(\mathrm{p}, J=7.0 \mathrm{~Hz}, 2 \mathrm{H},\left(\mathrm{CH}_{2}\right)_{2}\left(\mathrm{CH}_{2}\right)_{2}\left(\mathrm{CH}_{2}\right)_{2}\right)$.

${ }^{13} \mathrm{C} \mathrm{NMR}\left(126 \mathrm{MHz}, \mathrm{CDCl}_{3}\right) \delta: 168.41,133.89,132.12,123.17,37.82,33.72,32.60,28.41,27.70,26.02$.

b) General procedure for the synthesis of 1-(n-phthalimidoalkyl)-2,4,6-trioxo-1,3,5triazine $(n=2$ to 6$)$

$2.75 \mathrm{~g}$ (21.35 mmol, 4 eq.) of cyanuric acid was dissolved in $90 \mathrm{~mL}$ anhydrous dimethyl sulfoxide. To the solution $1,8-$ diazabicyclo[5.4.0] undec-7-ene (1.01 eq.) was added and the solution was stirred at room temperature for $30 \mathrm{~min}$. N-(nbromoalkyl)phthalimide (1 eq.) was added and the reaction mixture was stirred at $70^{\circ} \mathrm{C}$ for $7 \mathrm{~h}$. After cooling at room temperature the solvent was removed under reduced pressure. To the residue water was added and the suspension was stirred at $50^{\circ} \mathrm{C}$ for 30 minutes. The solids were separated by filtration. The procedure was repeated until no free cyanuric acid was detected by ${ }^{1} \mathrm{H}$ NMR. Purified 1-(n-phthalimidoalkyl)-2,4,6-trioxo-1,3,5-triazine were dried in air.

1-(2-phthalimidoethyl)-2,4,6-trioxo-1,3,5-triazine. Yield: $63.1 \%$ 
${ }^{1} \mathrm{H}$ NMR (500 MHz, DMSO) $\delta: 11.47$ (s (broad), 2H, CAH), $7.91-7.80$ (m, 4H, ArH), $3.96-3.91$ (m, 2H, $\mathrm{PhNCH}_{2}$ ), 3.86 $-3.80\left(\mathrm{~m}, 2 \mathrm{H}, \mathrm{CH}_{2} \mathrm{NCA}\right)$.

${ }^{13} \mathrm{C}$ NMR (126 MHz, DMSO) $\delta: 168.46,150.41,148.88,134.96,131.92,123.62,36.18$.

1-(3-phthalimidopropyl)-2,4,6-trioxo-1,3,5-triazine. Yield: 11\%

1H NMR (400 MHz, DMSO) $\delta 11.45(\mathrm{~s}, 2 \mathrm{H}, \mathrm{CAH}), 7.99-7.73(\mathrm{~m}, 4 \mathrm{H}, \mathrm{ArH}), 3.67\left(\mathrm{t}, J=7.4 \mathrm{~Hz}, 2 \mathrm{H}, \mathrm{PhNCH}_{2}\right), 3.60(\mathrm{t}, J=$ $\left.7.1 \mathrm{~Hz}, 2 \mathrm{H}, \mathrm{CH}_{2} \mathrm{NCA}\right), 1.88\left(\mathrm{p}, J=7.2 \mathrm{~Hz}, 2 \mathrm{H}, \mathrm{CH}_{2} \mathrm{CH}_{2} \mathrm{CH}_{2}\right.$ ).

1-(4-phthalimidobutyl)-2,4,6-trioxo-1,3,5-triazine. Yield: $56.6 \%$

${ }^{1} \mathrm{H}$ NMR $(400 \mathrm{MHz}, \mathrm{DMSO}) \delta 11.36(\mathrm{~s}, 2 \mathrm{H}, \mathrm{CAH}), 7.87-7.80(\mathrm{~m}, 4 \mathrm{H}, \mathrm{ArH}), 3.68\left(\mathrm{t}, J=6.8 \mathrm{~Hz}, 2 \mathrm{H}, \mathrm{CANCH}_{2}\right), 3.57(\mathrm{t}, J=$ $\left.6.6 \mathrm{~Hz}, 2 \mathrm{H}, \mathrm{PhNCH}_{2}\right), 1.62-1.56\left(\mathrm{~m}, 2 \mathrm{H}, \mathrm{PhNCH}_{2} \mathrm{CH}_{2}\right), 1.58-1.49\left(\mathrm{~m}, 2 \mathrm{H}, \mathrm{CANCH}_{2} \mathrm{CH}_{2}\right)$.

${ }^{13} \mathrm{C}$ NMR (126 MHz, DMSO) $\delta: 168.41,150.50,149.24,134.84,132.06,123.47,41.32,37.53,25.61,25.11$.

1-(5-phthalimidopentyl)-2,4,6-trioxo-1,3,5-triazine. Yield: $35.7 \%$

1H NMR ( $500 \mathrm{MHz}, \mathrm{DMSO}) \delta 11.32(\mathrm{~s}, 2 \mathrm{H}, \mathrm{CAH}), 7.96-7.71(\mathrm{~m}, 4 \mathrm{H}, \mathrm{ArH}), 3.61\left(\mathrm{t}, J=7.2 \mathrm{~Hz}, 2 \mathrm{H}, \mathrm{CANCH}_{2}\right), 3.56(\mathrm{t}, J$ $\left.=7.0 \mathrm{~Hz}, 2 \mathrm{H}, \mathrm{PhNCH}_{2}\right), 1.59\left(\mathrm{p}, J=7.4,2 \mathrm{H}, \mathrm{PhNCH}_{2} \mathrm{CH}_{2}\right), 1.53\left(\mathrm{p}, J=7.0 \mathrm{~Hz}, 2 \mathrm{H}, \mathrm{CANCH}_{2} \mathrm{CH}_{2}\right), 1.26(\mathrm{p}, J=7.6 \mathrm{~Hz}, 2 \mathrm{H}$, $\left.\left(\mathrm{CH}_{2}\right)_{2} \mathrm{CH}_{2}\left(\mathrm{CH}_{2}\right)_{2}\right)$.

${ }^{13} \mathrm{C}$ NMR (126 MHz, DMSO) $\delta$ 168.40, 150.40, 150.34, 149.16, 134.81, 132.06, 123.44, 40.89, 37.65, 28.13, 27.44, 23.91.

1-(6-phthalimidohexyl)-2,4,6-trioxo-1,3,5-triazine. Yield: $12.9 \%$

${ }^{1} \mathrm{H}$ NMR (500 MHz, DMSO) $\delta 11.37(\mathrm{~s}, 2 \mathrm{H}, \mathrm{CAH}), 7.98-7.73(\mathrm{~m}, 4 \mathrm{H}, \mathrm{ArH}), 3.61\left(\mathrm{t}, J=7.5 \mathrm{~Hz}, 2 \mathrm{H}, \mathrm{CANCH}_{2}\right), 3.55(\mathrm{t}, J=$ $\left.7.1 \mathrm{~Hz}, 2 \mathrm{H}, \mathrm{PhNCH}_{2}\right), 1.58\left(\mathrm{p}, J=6.6 \mathrm{~Hz}, 2 \mathrm{H}, \mathrm{CANCH}_{2} \mathrm{CH}_{2}\right), 1.49\left(\mathrm{p}, J=6.7 \mathrm{~Hz}, 2 \mathrm{H}, \mathrm{PhNCH}_{2} \mathrm{CH}_{2}\right), 1.28(\mathrm{p}, J=3.6 \mathrm{~Hz}$, $\left.4 \mathrm{H},\left(\mathrm{CH}_{2}\right)_{2}\left(\mathrm{CH}_{2}\right)_{2}\left(\mathrm{CH}_{2}\right)_{2}\right)$.

${ }^{13} \mathrm{C}$ NMR (126 MHz, DMSO) $\delta 168.42,150.31,149.10,134.83,132.08,123.46,123.44,40.76,37.77,28.31,27.70,26.42$, 26.13.

c) General procedure for the synthesis of $\mathrm{CA}-\mathrm{Cn}-\mathrm{NH}_{2}(\mathrm{n}=2$ to 6 )

1-(n-phthalimidoalyl)-2,4,6-trioxo-1,3,5-triazine $(0.5 \mathrm{mmol}$, 1 eq.) was dissolved in $10 \mathrm{~mL}$ EtOH. To the solution methylamine ( $40 \%$ in $\mathrm{H}_{2} \mathrm{O}$ or $\mathrm{MeOH}$ ) (40 eq.) was added and the reaction mixture was heated at $70^{\circ}$ for $2.5 \mathrm{~h}$. After the mixture has cooled, the white precipitate was separated by filtration, washed with $\mathrm{EtOH}$ and dried. The products were characterized with HRMS, ${ }^{1} \mathrm{H}$ and ${ }^{13} \mathrm{C}$ NMR. 
CA-C2-NH 2 : Yield: $52.1 \%$. HRESI-MS calc: 173.0669 found: 173.0663

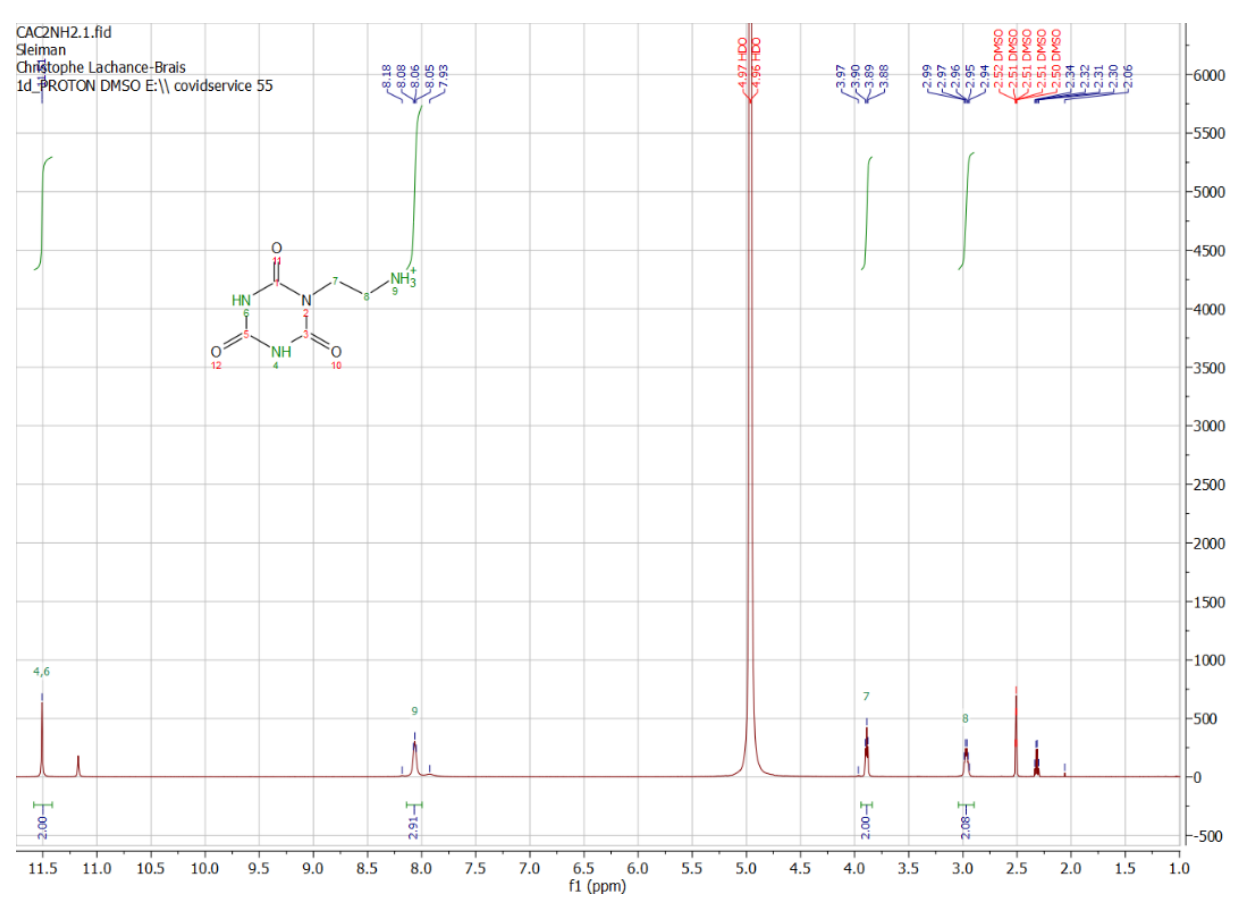

${ }^{1} \mathrm{H}$ NMR $\left(500 \mathrm{MHz}, \mathrm{DMSO}-d_{6}\right) \delta 11.51(\mathrm{~s}, 2 \mathrm{H}), 8.06(\mathrm{t}, J=5.9 \mathrm{~Hz}, 3 \mathrm{H}), 3.89(\mathrm{t}, J=5.8 \mathrm{~Hz}, 2 \mathrm{H}), 2.97(\mathrm{~h}, J=5.9 \mathrm{~Hz}, 2 \mathrm{H})$.

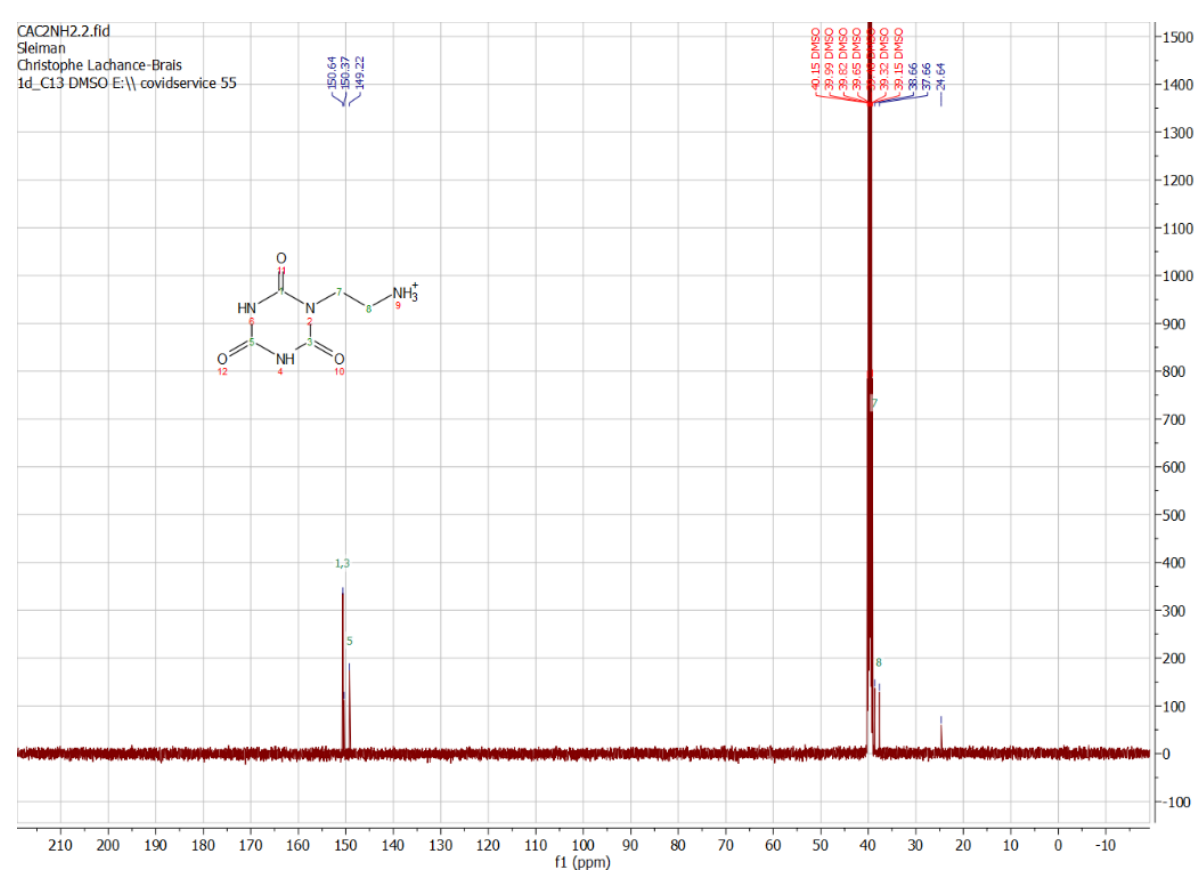


${ }^{13} \mathrm{C}$ NMR $\left(126 \mathrm{MHz}, \mathrm{DMSO}-d_{6}\right) \delta 150.64,149.22,38.66,37.66$.

CA-C3-NH $\mathrm{NH}_{2}$ : Yield: $42.06 \%$ HRESI-MS calc: 187.0826 found: 187.0817

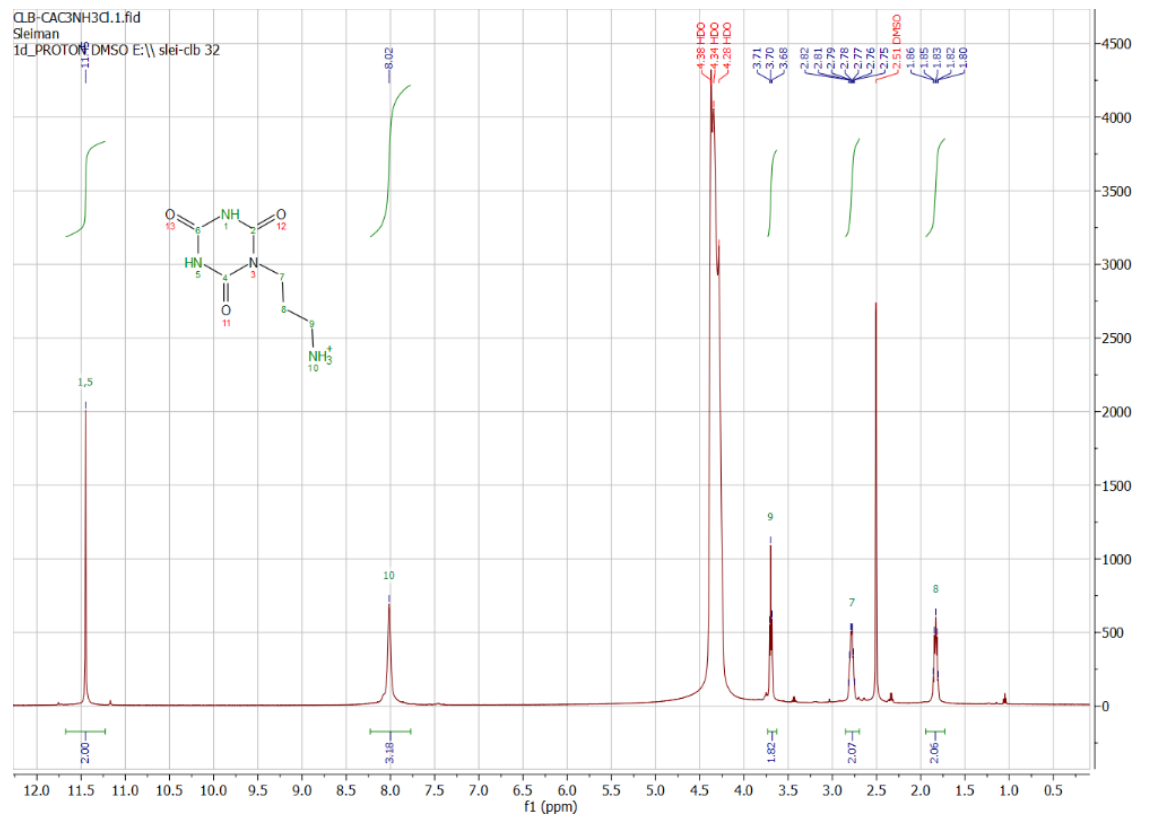

${ }^{1} \mathrm{H}$ NMR (500 MHz, DMSO-d $) \delta 11.45(\mathrm{~s}, 2 \mathrm{H}), 8.02(\mathrm{~s}, 3 \mathrm{H}), 3.70(\mathrm{t}, J=6.7 \mathrm{~Hz}, 2 \mathrm{H}), 2.78(\mathrm{dq}, J=11.9,6.1 \mathrm{~Hz}, 2 \mathrm{H}), 1.83$ $(p, J=6.9 \mathrm{~Hz}, 2 \mathrm{H})$.

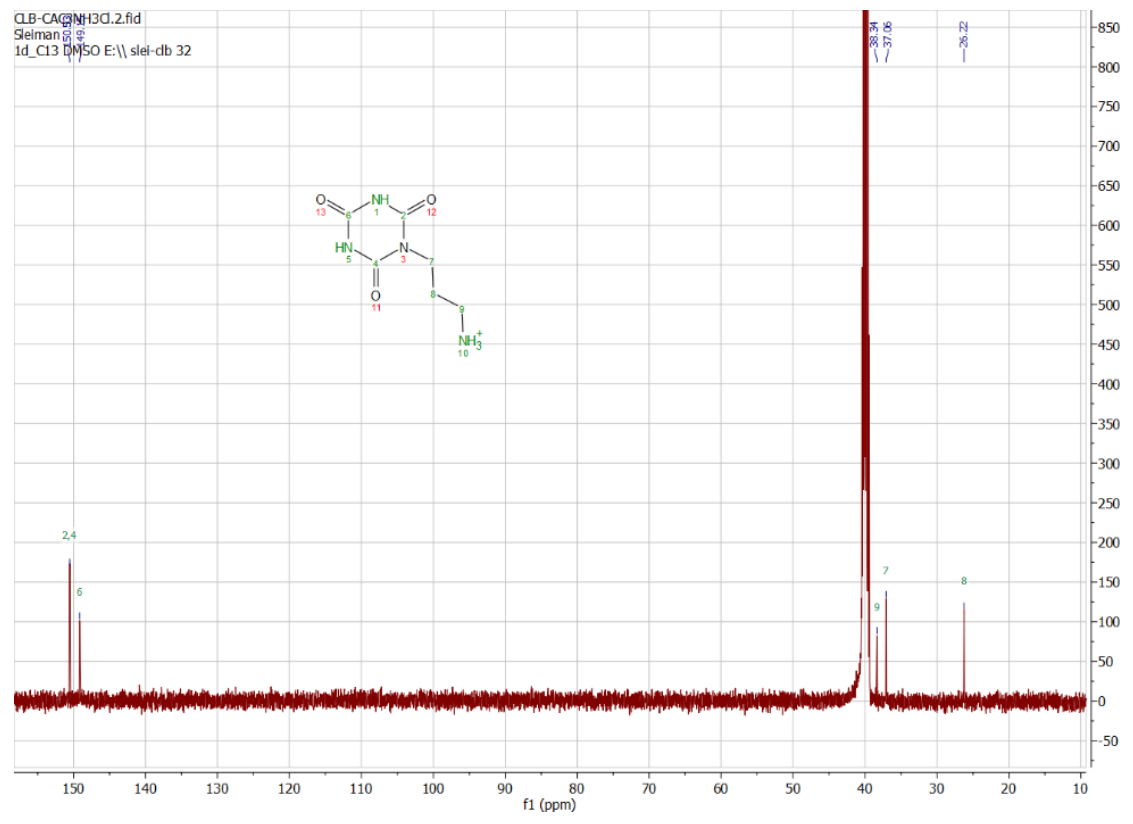


${ }^{13} \mathrm{C}$ NMR $\left(126 \mathrm{MHz}\right.$, DMSO- $\left.d_{6}\right) \delta 150.53,149.15,38.34,37.06,26.22$.

CA-C4-NH $\mathrm{NH}_{2}$ : Yield: $49.5 \%$ HRESI-MS calc: 201.0982 found: 201.0981

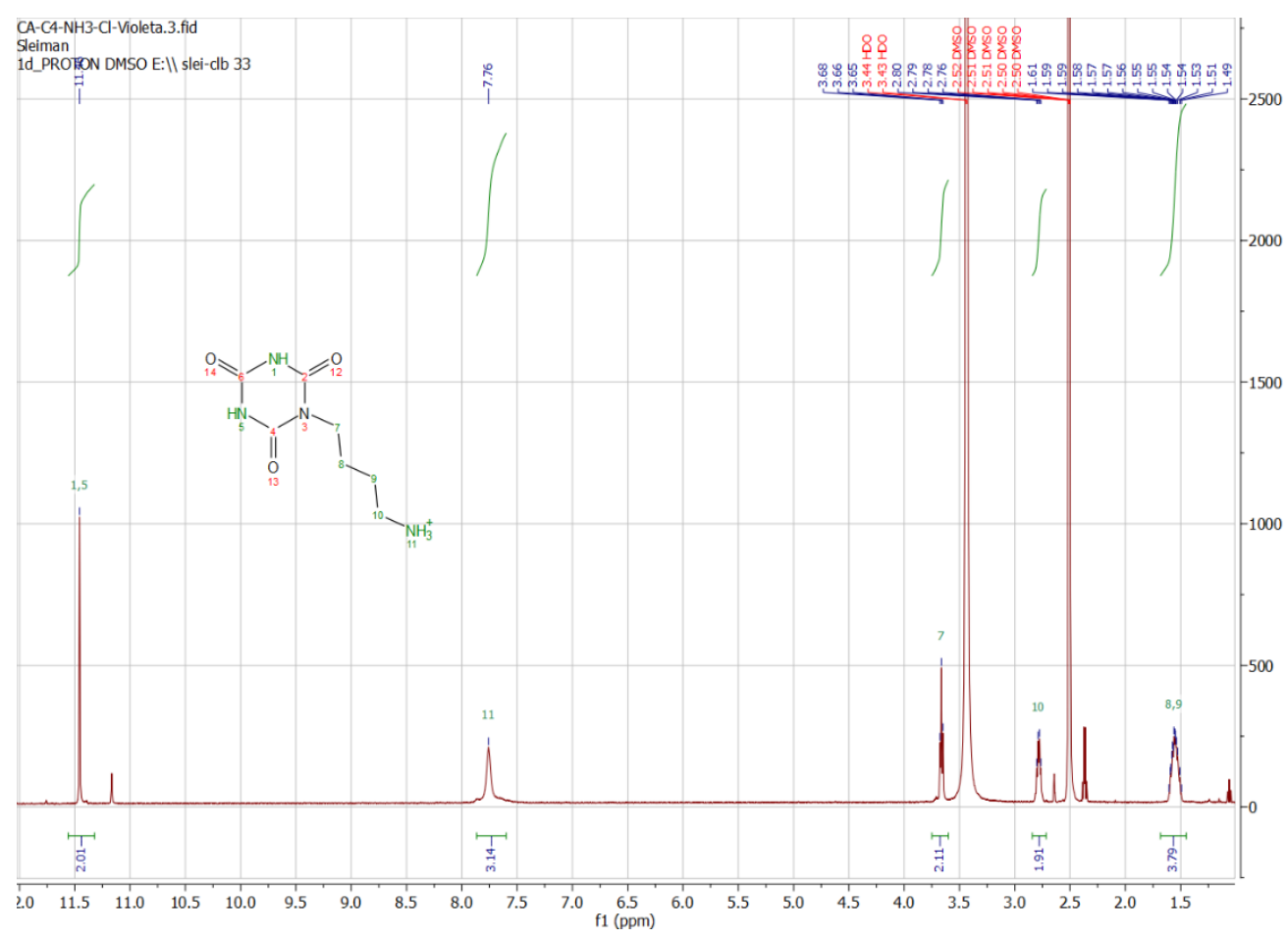

${ }^{1} \mathrm{H} \mathrm{NMR}\left(500 \mathrm{MHz}, \mathrm{DMSO}-d_{6}\right) \delta 11.46(\mathrm{~s}, 2 \mathrm{H}), 7.76(\mathrm{~s}, 3 \mathrm{H}), 3.66(\mathrm{t}, J=6.4 \mathrm{~Hz}, 2 \mathrm{H}), 2.79(\mathrm{p}, J=6.3 \mathrm{~Hz}, 2 \mathrm{H}), 1.56(\mathrm{ddt}, J=$ $18.0,15.5,5.9 \mathrm{~Hz}, 4 \mathrm{H})$. 


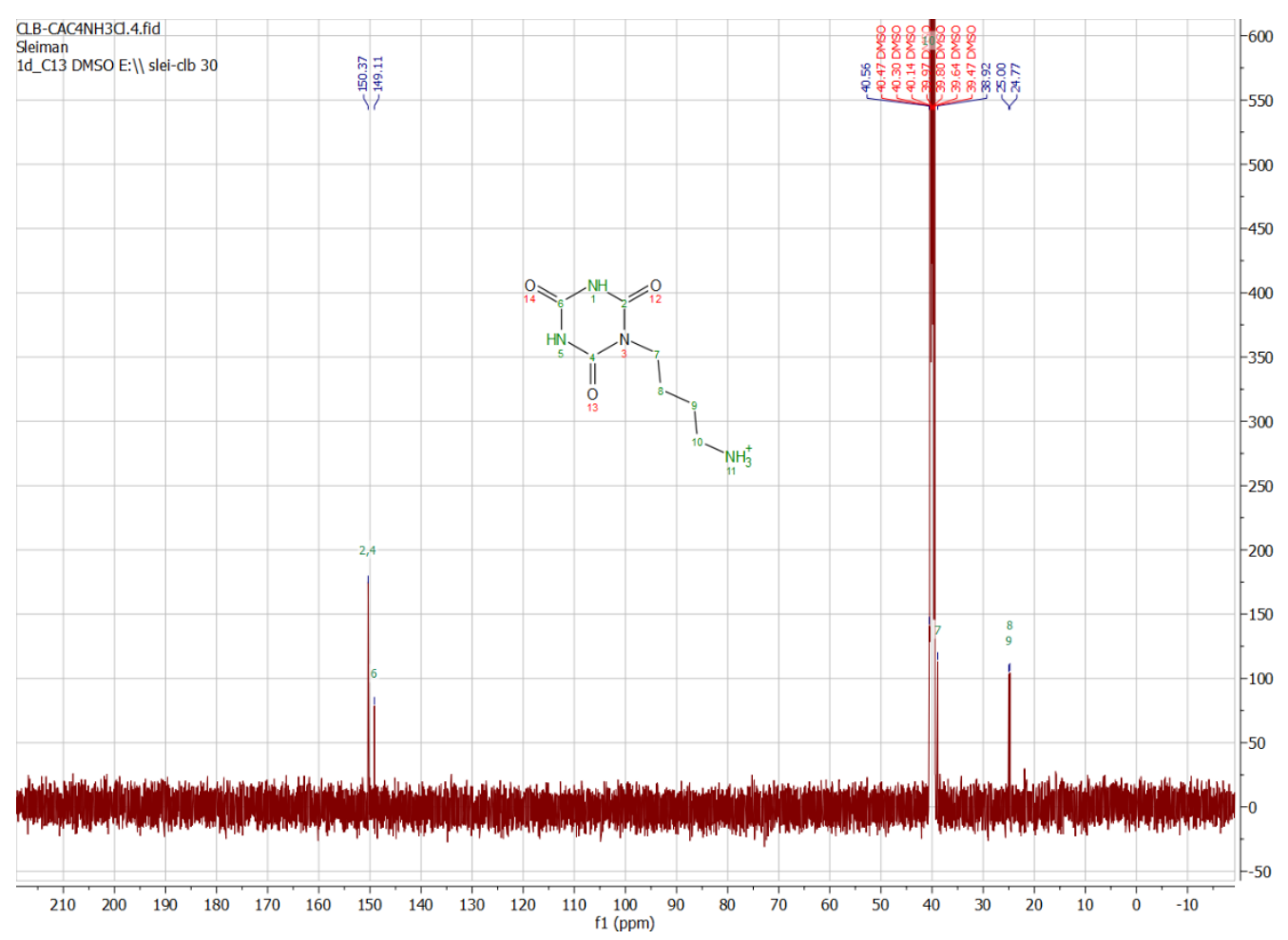

${ }^{13} \mathrm{C}$ NMR $(126 \mathrm{MHz}$, DMSO-d6) $\delta 150.37,149.11,40.56,38.92,25.00,24.77$.

CA-C5-NH2 $:$ Yield: $41.8 \%$ HRESI-MS calc: 215.1139 found: 215.1130

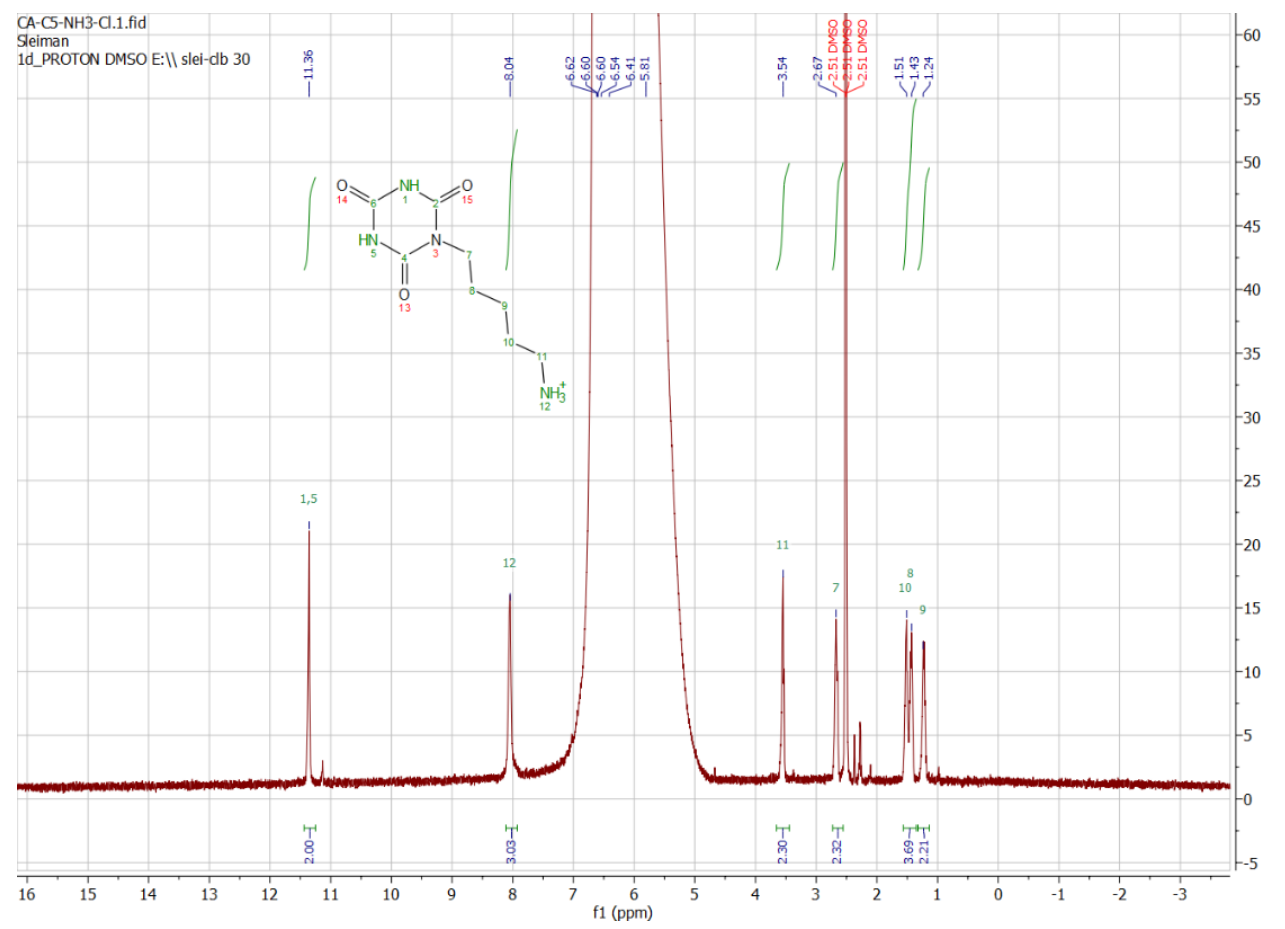

${ }^{1} \mathrm{H}$ NMR (500 MHz, DMSO-d $) \delta 11.44-11.25(\mathrm{~m}, 2 \mathrm{H}), 8.11-7.92(\mathrm{~m}, 3 \mathrm{H}), 3.65-3.44(\mathrm{~m}, 2 \mathrm{H}), 2.73-2.56(\mathrm{~m}, 2 \mathrm{H})$, $1.56-1.35(\mathrm{~m}, 4 \mathrm{H}), 1.32-1.13(\mathrm{~m}, 2 \mathrm{H})$. 


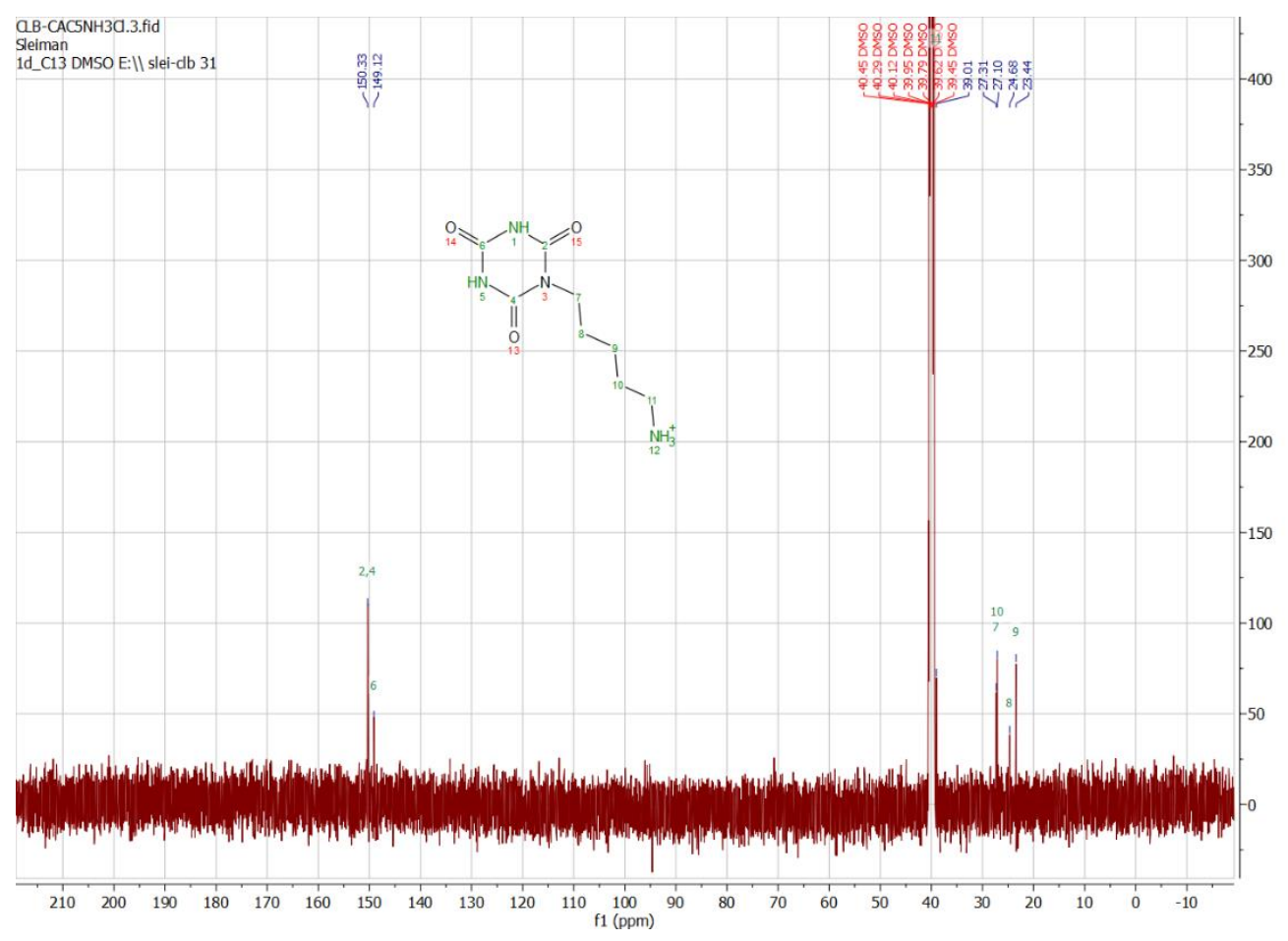

${ }^{13} \mathrm{C}$ NMR $(126 \mathrm{MHz}$, DMSO-d 6 ) $\delta$ 150.33, 149.12, 39.01, 27.31, 27.10, 24.68, 23.44.

CA-C6-NH $\mathrm{N}_{2}$ : Yield: $57.0 \%$ HRESI-MS calc: 229.1295 found: 229.1287

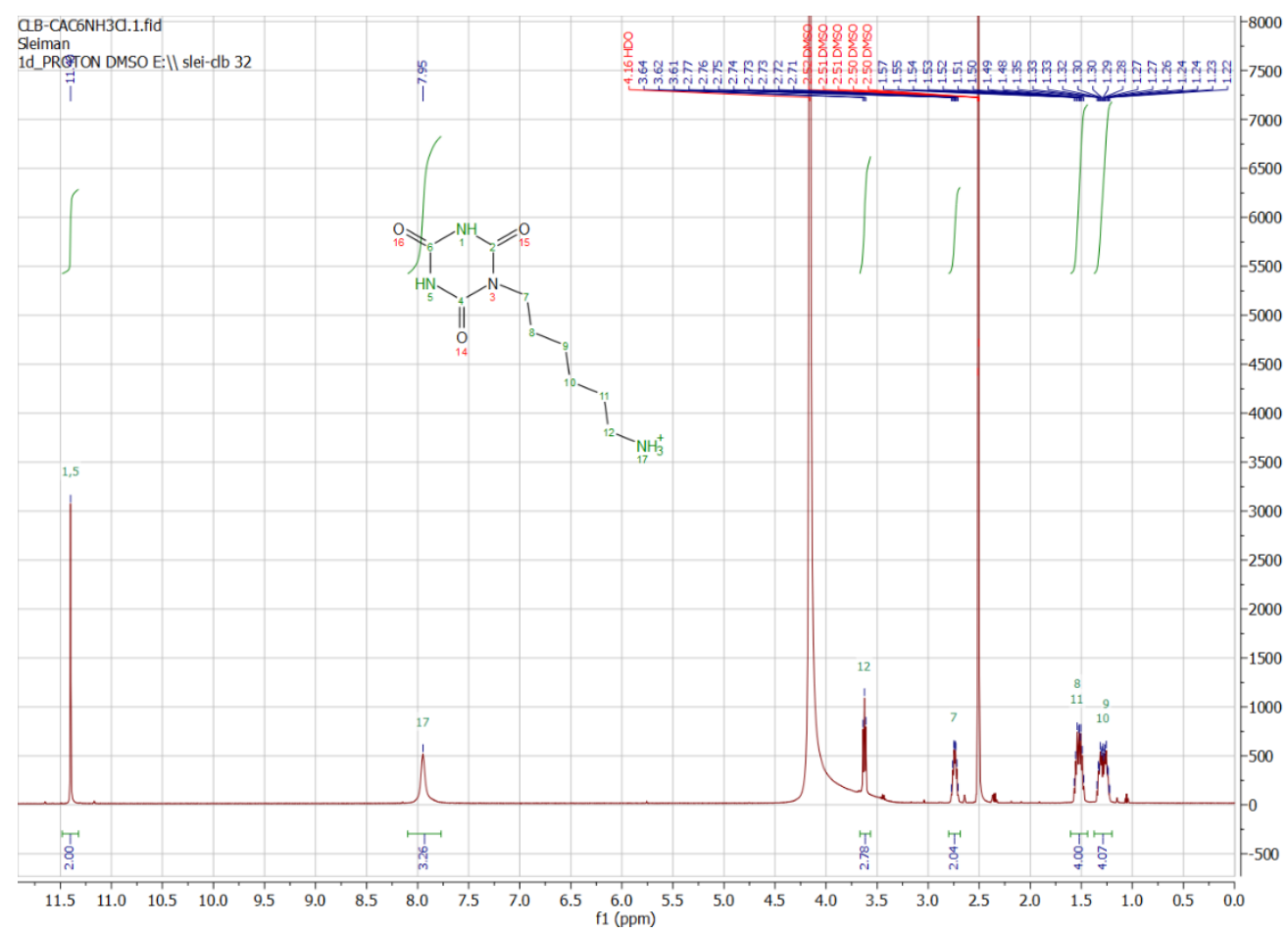

${ }^{1} \mathrm{H}$ NMR $\left(500 \mathrm{MHz}, \mathrm{DMSO}-d_{6}\right) \delta 11.40(\mathrm{~s}, 2 \mathrm{H}), 7.95(\mathrm{~s}, 3 \mathrm{H}), 3.62(\mathrm{t}, J=7.3 \mathrm{~Hz}, 3 \mathrm{H}), 2.73(\mathrm{tt}, J=11.6,6.1 \mathrm{~Hz}, 2 \mathrm{H}), 1.60$ $-1.44(\mathrm{~m}, 4 \mathrm{H}), 1.38-1.20(\mathrm{~m}, 4 \mathrm{H})$. 


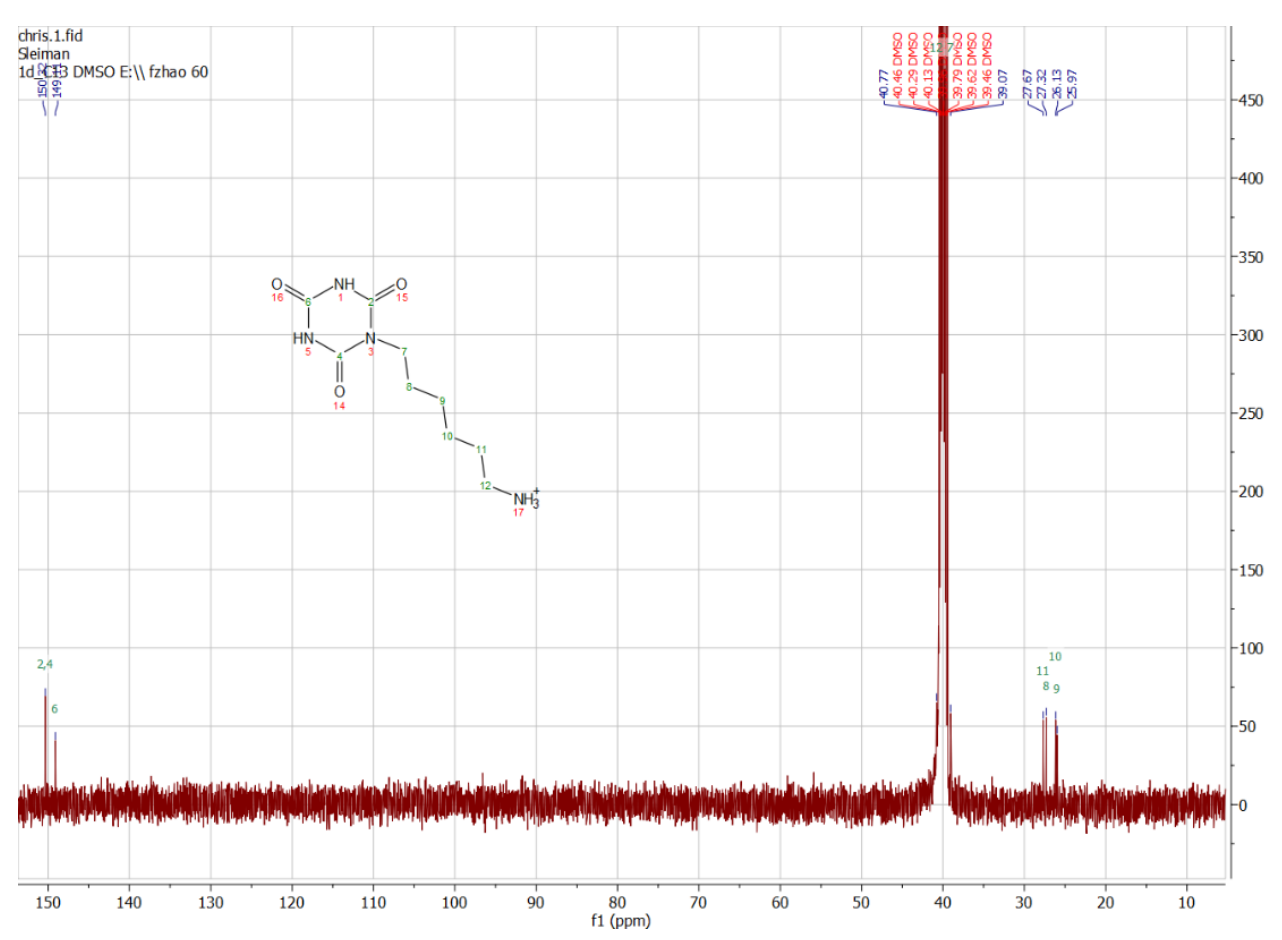

${ }^{13} \mathrm{C}$ NMR $\left(126 \mathrm{MHz}\right.$, DMSO-d $\left.d_{6}\right) \delta 150.32,149.11,40.77,39.07,27.67,27.32,26.13,25.97$.

The syntheses are adapted from the literature procedures reported by Yagai et al. ${ }^{31}$ and Felix et al. ${ }^{30}$

1. Mergny, J.-L.; Lacroix, L., Analysis of Thermal Melting Curves. Oligonucleotides 2003, 13 (6), 515537.

2. Hennecker, C.; Lachance-Brais, C.; Sleiman, H.; Mittermaier, A. Using transient equilibria (TREQ) to measure the thermodynamics of slowly assembling supramolecular systems. 2021. ChemRxiv, This content is a preprint and has not been peer-reviewed. 10.33774/chemrxiv-2021-mvjaq-v2 . (accessed 2021-10-20).

3. Efron, B.; Tibshirani, R., Bootstrap Methods for Standard Errors, Confidence Intervals, and Other Measures of Statistical Accuracy. Statistical Science 1986, 1 (1), 54-75, 22.

4. Alenaizan, A.; Barnett, J. L.; Hud, N. V.; Sherrill, C. D.; Petrov, A. S., The proto-Nucleic Acid Builder: a software tool for constructing nucleic acid analogs. Nucleic Acids Research 2020, 49 (1), 79-89.

5. Hawkins, G. D.; Cramer, C. J.; Truhlar, D. G., Pairwise solute descreening of solute charges from a dielectric medium. Chemical Physics Letters 1995, 246 (1), 122-129.

6. Hawkins, G. D.; Cramer, C. J.; Truhlar, D. G., Parametrized Models of Aqueous Free Energies of Solvation Based on Pairwise Descreening of Solute Atomic Charges from a Dielectric Medium. The Journal of Physical Chemistry 1996, 100 (51), 19824-19839.

7. Tsui, V.; Case, D. A., Theory and applications of the generalized born solvation model in macromolecular simulations. Biopolymers 2000, 56 (4), 275-291.

8. D.A. Case, H. M. A., K. Belfon, I.Y. Ben-Shalom, S.R. Brozell, D.S. Cerutti, T.E. Cheatham, III, V.W.D. Cruzeiro, T.A. Darden, R.E. Duke, G. Giambasu, M.K. Gilson, H. Gohlke, A.W. Goetz, R. Harris, S. Izadi, S.A. Izmailov, C. Jin, K. Kasavajhala, M.C. Kaymak, E. King, A. Kovalenko, T. Kurtzman, T.S. Lee, S. LeGrand, P. 
Li, C. Lin, J. Liu, T. Luchko, R. Luo, M. Machado, V. Man, M. Manathunga, K.M. Merz, Y. Miao, O. Mikhailovskii, G. Monard, H. Nguyen, K.A. O’Hearn, A. Onufriev, F. Pan, S. Pantano, R. Qi, A. Rahnamoun, D.R. Roe, A. Roitberg, C. Sagui, S. Schott-Verdugo, J. Shen, C.L. Simmerling, N.R. Skrynnikov, J. Smith, J. Swails, R.C. Walker, J. Wang, H. Wei, R.M. Wolf, X. Wu, Y. Xue, D.M. York, S. Zhao, and P.A. Kollman, Amber 2020. University of California, San Francisco: 2020.

9. $\quad$ Eastman, P.; Swails, J.; Chodera, J. D.; McGibbon, R. T.; Zhao, Y.; Beauchamp, K. A.; Wang, L.-P.; Simmonett, A. C.; Harrigan, M. P.; Stern, C. D.; Wiewiora, R. P.; Brooks, B. R.; Pande, V. S., OpenMM 7: Rapid development of high performance algorithms for molecular dynamics. PLOS Computational Biology 2017, 13 (7), e1005659.

10. Alenaizan, A.; Fauche, K.; Krishnamurthy, R.; Sherrill, C. D., Noncovalent Helicene Structure between Nucleic Acids and Cyanuric Acid. Chemistry 2020.

11. Miyamoto, S.; Kollman, P. A., Settle: An analytical version of the SHAKE and RATTLE algorithm for rigid water models. Journal of Computational Chemistry 1992, 13 (8), 952-962.

12. Galindo-Murillo, R.; Robertson, J. C.; Zgarbová, M.; Šponer, J.; Otyepka, M.; Jurečka, P.; Cheatham, T. E., Assessing the Current State of Amber Force Field Modifications for DNA. Journal of Chemical Theory and Computation 2016, 12 (8), 4114-4127.

13. Jorgensen, W. L.; Chandrasekhar, J.; Madura, J. D.; Impey, R. W.; Klein, M. L., Comparison of simple potential functions for simulating liquid water. The Journal of Chemical Physics 1983, 79 (2), 926-935.

14. Joung, I. S.; Cheatham, T. E., Determination of Alkali and Halide Monovalent lon Parameters for Use in Explicitly Solvated Biomolecular Simulations. The Journal of Physical Chemistry B 2008, 112 (30), 9020-9041.

15. Aduri, R.; Psciuk, B. T.; Saro, P.; Taniga, H.; Schlegel, H. B.; SantaLucia, J., AMBER Force Field Parameters for the Naturally Occurring Modified Nucleosides in RNA. Journal of Chemical Theory and Computation 2007, 3 (4), 1464-1475.

16. Bayly, C. I.; Cieplak, P.; Cornell, W.; Kollman, P. A., A well-behaved electrostatic potential based method using charge restraints for deriving atomic charges: the RESP model. The Journal of Physical Chemistry 1993, 97 (40), 10269-10280.

17. Alenaizan, A.; Burns, L. A.; Sherrill, C. D., Python implementation of the restrained electrostatic potential charge model. International Journal of Quantum Chemistry 2020, 120 (2), e26035.

18. Smith, D. G. A.; Burns, L. A.; Simmonett, A. C.; Parrish, R. M.; Schieber, M. C.; Galvelis, R.; Kraus, P.; Kruse, H.; Remigio, R. D.; Alenaizan, A.; James, A. M.; Lehtola, S.; Misiewicz, J. P.; Scheurer, M.; Shaw, R. A.; Schriber, J. B.; Xie, Y.; Glick, Z. L.; Sirianni, D. A.; O’Brien, J. S.; Waldrop, J. M.; Kumar, A.; Hohenstein, E. G.; Pritchard, B. P.; Brooks, B. R.; SchaeferlII, H. F.; Sokolov, A. Y.; Patkowski, K.; DePrincellI, A. E.; Bozkaya, U.; King, R. A.; Evangelista, F. A.; Turney, J. M.; Crawford, T. D.; Sherrill, C. D., PSI4 1.4: Opensource software for high-throughput quantum chemistry. The Journal of Chemical Physics 2020, 152 (18), 184108.

19. Lu, X.-J.; Olson, W. K., 3DNA: a versatile, integrated software system for the analysis, rebuilding and visualization of three-dimensional nucleic-acid structures. Nature Protocols 2008, 3 (7), 1213-1227.

20. Hai Nguyen, Daniel R. Roe, ., Jason Swails, ., \& David A. Case, PYTRAJ v1.0.0.dev1: Interactive data analysis for molecular dynamics simulations (Version v1.0.0.dev1). Zenodo 2016.

21. Eberly, D., Least squares fitting of data by linear or quadratic structures. 1999.

22. Humphrey, W.; Dalke, A.; Schulten, K., VMD: Visual molecular dynamics. Journal of Molecular Graphics 1996, 14 (1), 33-38.

23. Avakyan, N.; Greschner, A. A.; Aldaye, F.; Serpell, C. J.; Toader, V.; Petitjean, A.; Sleiman, H. F., Reprogramming the assembly of unmodified DNA with a small molecule. Nat Chem 2016, 8, 368.

24. Sheng, Y.; Zhou, K.; Liu, Q.; Liu, L.; Wu, H.-C., Probing Conformational Polymorphism of DNA Assemblies with Nanopores. Anal. Chem. (Washington, DC, U. S.) 2020, 92 (11), 7485-7492. 
25. Harkness V, R. W.; Avakyan, N.; Sleiman, H. F.; Mittermaier, A. K., Mapping the energy landscapes of supramolecular assembly by thermal hysteresis. Nature Communications 2018, 9, 3152.

26. Foloppe, N.; Hartmann, B.; Nilsson, L.; MacKerell, A. D., Jr., Intrinsic Conformational Energetics Associated with the Glycosyl Torsion in DNA: A Quantum Mechanical Study. Biophysical Journal 2002, 82 (3), 1554-1569.

27. Gelbin, A.; Schneider, B.; Clowney, L.; Hsieh, S.-H.; Olson, W. K.; Berman, H. M., Geometric Parameters in Nucleic Acids: Sugar and Phosphate Constituents. J Am Chem Soc 1996, 118 (3), 519-529.

28. Dunnigan, D. A.; Close, W. J., Anticonvulsant Drugs. VI. Some 1-Substituted Biurets1. J Am Chem Soc 1953, 75 (15), 3615-3616.

29. Close, W. J., Anticonvulsant Drugs. VII. Some Monosubstituted Isocyanurates1. J Am Chem Soc 1953, 75 (15), 3617-3618.

30. Félix, O.; Crego-Calama, M.; Luyten, I.; Timmerman, P.; Reinhoudt, David N., Covalent Linkage of Melamine and Cyanurate Improves the Thermodynamic Stability of Hydrogen-Bonded Double Rosettes in Polar Solvents. European Journal of Organic Chemistry 2003, 2003 (8), 1463-1474.

31. Yagai, S.; Usui, M.; Seki, T.; Murayama, H.; Kikkawa, Y.; Uemura, S.; Karatsu, T.; Kitamura, A.; Asano, A.; Seki, S., Supramolecularly Engineered Perylene Bisimide Assemblies Exhibiting Thermal Transition from Columnar to Multilamellar Structures. J Am Chem Soc 2012, 134 (18), 7983-7994. 